\title{
The Upper Paleolithic Rock Art of Iberia
}

\author{
Nuno Bicho, ${ }^{1}$ Antonio F. Carvalho, ${ }^{1}$ Cesar González-Sainz, ${ }^{2}$ \\ Jose Luis Sanchidrián, ${ }^{3}$ Valentín Villaverde, ${ }^{4}$ and Lawrence G. Straus ${ }^{2,5}$
}

Published online: 22 February 2007

Nearly 200 rock art sites of Upper Paleolithic age are currently known on the Iberian Peninsula, in both caves and the open air. Over half are still concentrated in Cantabrian Spain and they span the period between c. 30-11 kya, but-tracking the course of human demography in this geographically circumscribed regionmany of the images were probably painted or engraved during the Solutrean and, especially, Magdalenian. Dramatic discoveries and dating projects have significantly expanded the Iberian rock art record both geographically and temporally in recent years, in close coincidence with the growth of contemporaneous archeological evidence: cave art loci in Aragón and Levante attributable to the Solutrean and Magdalenian, many cave art sites and a few open-air ones in Andalucía and Extremadura that are mostly Solutrean (in line with evidence of a major Last Glacial Maximum human refugium in southern Spain), the spectacular Côa Valley open-air complex in northern Portugal (together with a growing number of other such loci and one cave) that was probably created during the GravettianMagdalenian periods, and a modest, but important increase in proven cave and open-air sites in the high, north-central interior of Spain that are probably Solutrean and/or Magdalenian. Despite regional variations in decorated surfaces, themes, techniques and styles, there are broad (and sometimes very specific) panIberian similarities (as well as ones with the Upper Paleolithic art of southern France) that are indicative of widespread human contacts and shared systems of symbols and beliefs during the late Last Glacial. As this Ice Age world and the forms of social relationships and ideologies that helped human groups survive in it came to an end, so too did the decoration of caves, rockshelters and outcrops,

\footnotetext{
${ }^{1}$ Departamento de História, Arqueologia e Patrimonio, Universidade do Algarve, Faro, Portugal.

${ }^{2}$ Instituto Internacional de Investigaciones Prehistóricas, Universidad de Cantabria, Santander, Spain.

${ }^{3}$ Area de Prehistoria, Universidad de Córdoba, Córdoba, Spain.

${ }^{4}$ Departamento de Prehistoria y Arqueología, Universidad de Valencia, Valencia, Spain.

${ }^{5}$ To whom correspondence should be addressed at Department of Anthropology, University of New Mexico, Albuquerque, NM 87131, USA; e-mail: 1straus@unm.edu

Note. Author names are in alphabetical order, except that of Straus, who translated and/or edited the sections by the others, organized the article, and wrote the introduction and conclusions.
} 
although in some regions other styles of rock art would return under very different conditions of human existence.

KEY WORDS: Upper Paleolithic; rock art; Spain; Portugal.

\section{INTRODUCTION: FROM ALTAMIRA TO CÔA (LGS)}

When in 1879 Marcelino Sanz de Sautuola took his eight-year old daughter, María, to accompany him in his explorations of Altamira Cave in Santillana del Mar (Cantabria), he and she entered a time tunnel leading to a glimpse of the expressive activities of the first anatomically modern humans to inhabit Europe during the Last Ice Age. The realization on part of Sanz de Sautuola's (1880, pp. 20-24) that the great bison and other animals pictured in Altamira were the creation of the same people who had left behind the artifacts and other cultural debris that he was excavating near the mouth of the cave was of fundamental importance. It ultimately opened the way for the discovery, validation and analysis of hundreds of Upper Paleolithic cave art sites in Spain and France, as well as smaller numbers in Italy, Portugal, Romania, Russia, and now England and possibly Germany.

It is telling that Sautuola was the first prehistorian to combine traditional archeological excavation with the study (however simple) of cave art. The integration of Upper Paleolithic archeological and art studies is felicitously once again considered the standard. It is also remarkable to reflect that Sautuola's travails and those of his advocate, the geologist Juan Vilanova, in attempting to gain acceptance for the Paleolithic age of the Altamira paintings (and engravings) (see Moro and González Morales, 2004) would be closely paralleled 110 years later by the fight to win recognition of similar antiquity and legitimacy for the then-equally implausible open-air rock art sites along the Côa River valley in NE Portugal. Sautuola died before his seminal discovery was widely accepted-ignored at best, accused of forgery at worst, but his work pioneered the study of rock art as part of a holistic discipline of prehistory.

In the 20 years between 1895 (with the discovery of La Mouthe in the Périgord of SW France) and the outbreak of World War I (with monumental discoveries from the French Pyrenees — such as le Tuc d'Audoubert and Les Trois Frères - to Andalucía with La Pileta, and in between — in Cantabria—La Pasiega), a few extraordinary prehistorians (e.g., Hermilio Alcalde del Río, Lorenzo Sierra, Edouard Piette, Emile Cartailhac, Henri Bégouën and especially Henri Breuil) created an essentially Franco-Cantabrian cave art record that would provide grist for the successive interpretive "mills" of Breuil, André Leroi-Gourhan and others, at least through the 1970s. For Cantabrian Spain alone, in the few short years between 1902 and 1910, when Breuil and Hugo Obermaier (his colleague at the newly created Institut de Paléontologie Humaine) began their full-scale research in the region, Alcalde del Río and Sierra separately or together discovered Covalanas, 
El Castillo, La Haza, El Salitre, Hornos de la Peña, Venta de la Perra, Santián, Sotarriza, El Pendo, La Meaza, La Franca, El Pindal, Quintana and Las Aguas. The numeric weight of known sites still greatly favors the Atlantic-draining regions of the greater French Southwest and the Spanish region of Vasco-Cantabria. However, today we know of rock art sites of definite or probable late Pleistocene age in many other regions of the Iberian Peninsula-including the newly discovered openair complexes of northern Portugal and east-central Spain-and two of the most important French cave art discoveries since that of Lascaux in 1940_-Cosquer and Chauvet - are in the Mediterranean Southeast. On the temporal axis, while we had come to believe that most cave art (like most mobiliary art) was of Magdalenian age (i.e., ca. 17-11 kya uncal.), recent years have seen a revolution in discoveries and dating that have revealed the presence of abundant and sophisticated Aurignacian (ca. 38-28 kya), Gravettian (ca. 28-20 kya) and Solutrean (ca. 20-17 kya) art that help track the demographic centers of human settlement in western Europe before and during the Last Glacial Maximum-including not only Chauvet, but also the ivory figurines of southwest Germany and the extraordinary concentration of Solutrean cave art sites in Andalucía.

The present article is an all-too-abbreviated tour d'horizon of the state of our knowledge of Upper Paleolithic rock art in Iberia, where revolutionary developments have built upon the classic Cantabrian record that had been created by Alcalde del Río, Breuil and Sierra in their still-unequalled Les Cavernes de la Région Cantabrique (1911), further enrichening it and expanding upon it in regions that were until recently poorly known or bereft of rock art sites. VascoCantabria now has some 116 known cave art sites, the north-central Castilian meseta 8 cave loci and 2 open-air complexes, Levantine Spain (plus Aragón) 14 cave sites, Andalucía (plus Extremadura) 21 cave loci and 2 open-air ones, Portugal 1 cave site and 31 open-air clusters, for an Iberian total of 195 sites, with more being discovered every year (Fig. 1). In comparison, the current total for France (with an area only slightly smaller than Iberia) is ca. 170 (Jean Clottes, personal communication, 2006). Nonetheless, in comparison with the French cave art record, that of Iberia is very little known in the world of Anglophone archeologists.

Following the hiatus in research due to the Spanish Civil War and World War II, Cantabria saw the discovery of a pair of cave art discoveries on Monte Castillo in the 1950s (Las Monedas, Las Chimeneas) that joined El Castillo and La Pasiega in Cantabria. There followed another pause in the pace of major finds until the series of cave art discoveries in the Basque Country (Ekain, Altxerri) and Asturias (Tito Bustillo, Llonín) in the late 1960s-early 1970s, after which the record "stabilized" again for nearly two decades. But in the 1990s, again "blockbuster" finds were made: the La Garma karstic complex (surprisingly close to the city of Santander) and Covaciella in the interior of E. Asturias. Cantabrian Spain seems to have an almost inexhaustible supply of cave art sites 


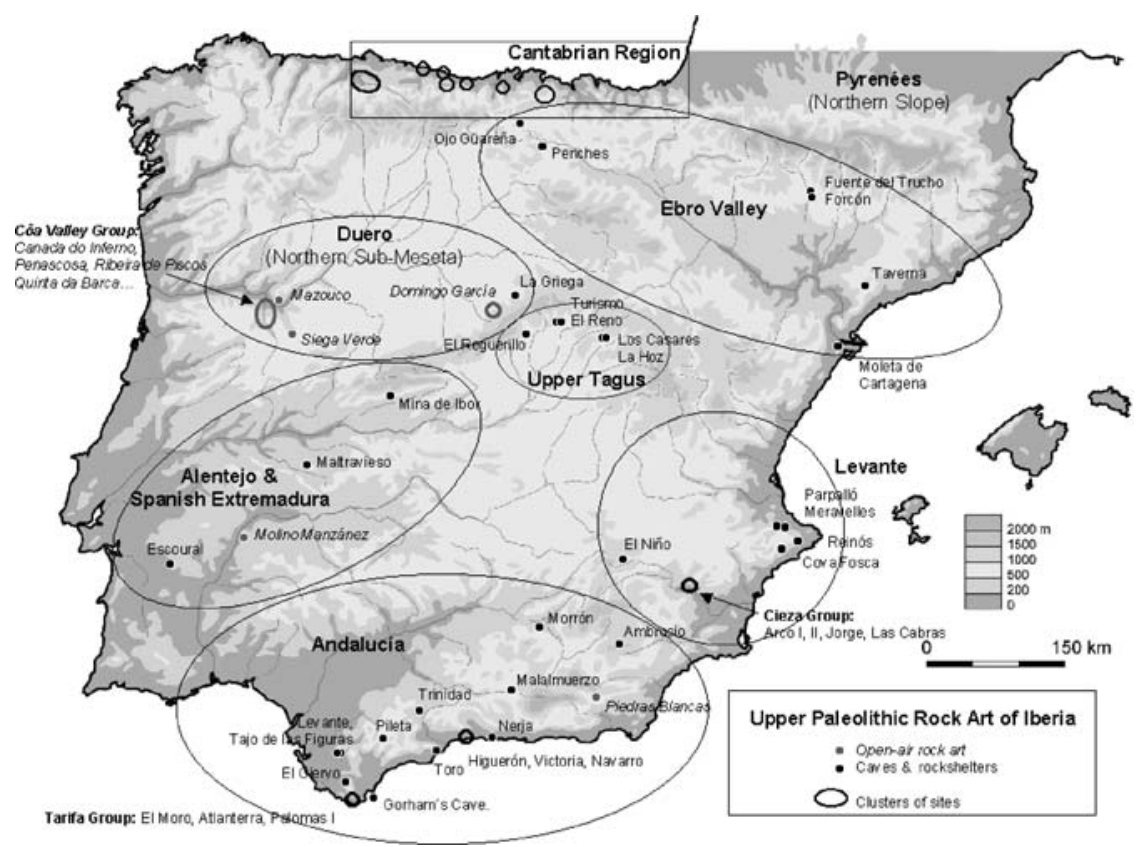

Fig. 1. The Upper Paleolithic Rock art of the Iberian Peninsula (C. González Sainz).

awaiting discovery, usually by speleologists. This fact is nothing new. What is new are:

1. discoveries of Paleolithic cave and rockshelter art in Levante and Aragón, where really none had been known before, the explosion of art sites in Andalucía (where in the "old days" there had been little more than La Pileta, Ardales and, more recently, the nonetheless little-known Nerja),

2. a restrained, but real increase in the number of both cave and, most recently open-air rock art sites in the central and northern hinterlands of Spain (despite the removal of one of the few "old" finds-Atapuerca's Cueva Mayor-from the roster of authentic sites), and

3. the "bombshell" discoveries along the Côa Valley that moved Portugal from a position of marginality in the world of Paleolithic art to one of central importance in the phenomenon of open-air rock art, eclipsing in scale the somewhat earlier discoveries at Fornols-Haut in the eastern French Pyrenees, Domingo Garcia in central Spain and Mazouco in the same region of northeastern Portugal.

The revolutionary art discoveries in Eastern, Southern and Central Spain, and in Portugal have come in close parallel with the growth of Paleolithic prehistoric archeological research in these regions (long very scarce in comparison to 
Vasco-Cantabria, with its long tradition of excavations). As evidence of human occupation at least in certain periods of the Upper Paleolithic has increased, so has the tempo of rock art discoveries (and vice versa in the case of Côa). (Ironically, one of the longest and, until recently, most intensively researched regions of Mediterranean Spain-Catalonia—still has no cave art loci except in its southernmost fringe, despite its wealth of Upper Paleolithic living sites, which, however, are concentrated in the region's northern areas.) Some of this has been serendipity, but in other cases it has been the result of deliberate, organized archeological survey, as in the case of the project of de Balbín and Alcolea in Guadalajara or the dam surveys in the Côa (post facto) and Alqueva valleys. Still it remains likely that the high, relatively inhospitable and resource-poor mountains and mesetas of the deep Spanish interior were at most sparsely inhabited during significant parts of the Last Glacial, especially in contrast to the favored coastal and near-coastal regions of Vasco-Cantabria, Levante, Portugal, and (especially in the Solutrean) Andalucía. Even though located in the interior of Portugal's Duero Basin, Côa is only $125 \mathrm{~km}$ from the Holocene shore (and about $150 \mathrm{~km}$ from that of the Last Glacial Maximum), while lithic raw material evidence from archeological sites at Côa suggest the existence of contacts with Portuguese Estremadura (to the southwest) and to areas of the Spanish interior (immediately to the east).

Iberian rock art research has been mainly preoccupied for decades with discoveries, documentation and dating. Grand interpretations of the art have been few, although there are exceptions, such as the work of Freeman, Gonzalez Echegaray and associates at Altamira - again made in association with excavation to confirm the classic finds of Obermaier, Alcalde del Río and Sautuola (Freeman et al., 1987; Freeman and González Echegaray, 2001). Freeman (2005) and González Echegaray (2005) have recently defended the notions that at least some (though not all) of the cave art complexes are in fact "sanctuaries" and that the old ideas of animal fertility and hunting magic actually do make sense, a spectacular example being the Great Ceiling of Altamira. This perspective has been developed on the basis of Freeman's ethological interpretations of the message of such images as the Altamira bison. In a related vein, González Morales (1997) discusses the relationships among subsistence strategies, game species, social organization, human mobility and artistic expression, pointing out that the importance thereof is highlighted as conditions of human existence changed at the end of the Last Glacial and the art disappeared. Another overarching and coherent interpretative approach has been Apellániz's analysis of authorship, by which very detailed technical and stylistic readings of both portable and cave art images are used (ambitiously and controversially) to identify particular ones may have been made by the same individual(s) (e.g., Apellániz, 1982, 1991; Altuna and Apellániz, 1978). This art historical method leads to postulation of the existence of local/regional schools of art (e.g., the "Ramales School" of red dot outline figures of hinds and other ungulates) that have possible implications in the determination of social territories (see Straus, 1982, 1987). 
Generally speaking, however, the recent emphasis in Iberia has been on detailed study of Paleolithic art in its archeological and geographic contexts, including close comparisons between mobiliary and rock art. The latter has most significantly involving the exhaustive reanalysis and then scientific exploitation by Villaverde (1994a) of the massive collection of painted and engraved slabs excavated in the late 1920s by Luis Pericot at the Valencian site of El Parpalló, of particular relevance to the validation, dating and study of the Côa open-air rock art clusters.

Finally, recent years have seen the attractive, color photo-laden, trade-market publications of Altamira (Saura and Beltrán, 1998) and of Ekain and Altxerri (Altuna, 1997). In response to concern for conservation, coupled with a need to foment tourism and to satisfy the growing public demand to see cave art, replicas of Altamira and Ekain have been built - the former as part of an ultra-modern museum focused on Cantabrian cave art in its paleoanthropological context, located adjacent to the real cave of Altamira. Few Iberian rock art sites are currently open to the public and those that are still open (e.g., Candamo, Buxú, Tito Bustillo, Pindal, Chufín, Castillo, Monedas, Hornos de la Peña, Pendo, Covalanas, Santimamiñe, Pileta, Nerja, Ardales, Casares, several Côa loci) have increasingly strict limitations on visitor numbers. Excellent interpretive centers have been constructed in association with both open and closed sites (e.g., Fuente del Trucho, Ardales, Côa). One of the ironies of the present situation is that just as the broad public (in both Europe and USA) is becoming aware of, fascinated by, and desirous of seeing Paleolithic rock art, archeologists (sometimes in opposition to local authorities, sometimes in collaboration with them) are coming to realize just how fragile this resource is and how restrictive we must be to protect it, if-having survived for 10-30 millennia so far-it is to survive the present century. The present article is a first attempt to succinctly synthesize the current state of our knowledge of the Paleolithic rock art of Spain and Portugal for a readership of English-speaking archeologists. However, it should be noted that current syntheses on a Peninsular scale are lacking even in Spanish or Portuguese, although an "atlas" is currently in preparation (Fortea, n.d.).

\section{CANTABRIAN SPAIN (CGS)}

The Atlantic coastal corridor of northern Spain, between the Cantabrian Cordillera and Sea, is replete with evidence of human activity during the Upper Paleolithic, including an extremely rich record of both mobiliary and rupestral art. The latter is the subject of this very abbreviated section, although there are notable cases of close similarities between certain styles of images created in both portable and parietal contexts, such as the long-famous striated engravings of ungulates (mainly red deer hinds) done on red deer scapulae and on the walls of El Castillo and Altamira, as first described by Breuil and Obermaier (1935), as well as on scapulae (always from the Lower Magdalenian, ca. 15-16 kya) from several 
other sites in the province of Cantabria (plus an outlier site in eastern Asturias), now including well-dated examples from El Mirón Cave (González Morales et al., 2005; n.d.). The wealth of the Cantabrian record is due to a combination of factors: a relatively high human demographic density (especially in the Late Upper Paleolithic: Solutrean and Magdalenian) as permitted by the abundance and diversity of resources that could be exploited by hunter-gatherers in this circumscribed, high-relief region, plus excellent conditions for the preservation of information in the many caves of this karstic limestone-rich region.

Following the discovery (in 1879) and ultimate acceptance (in 1902) of Altamira, the intensive work of documenting and analyzing the cave art of VascoCantabria during the 20th century by the Abbé Henri Breuil and many others (mainly Spaniards), created a distinctive image of this region's Paleolithic art that was maintained and even consolidated along similar lines until the end of the 1970s. Even the profoundly revolutionary work of André Leroi-Gourhan scarcely modified the reigning idea that the art was the product of special activities closely linked to universally transcendent behaviors with religious and ritual meaning, as articulated in relation to the concept of the "sanctuary" or ceremonial place, more or less disconnected from the tasks and concerns of daily life. In parallel with the rest of the prehistoric archeological record, and seen from a very formal viewpoint, the notion of the Upper Paleolithic artistic cycle was understood as a long-term process, during the course of which there developed mastery in the representation of animal figures, as characterized by ever-increasing realism. In this way, technical, formal and expressive variability observed in the art of this region had to be organized purely along a temporal axis and in very linear fashion.

As in other European regions, today many aspects of the phenomenon of Paleolithic graphic expression in the Cantabrian region are subject to debate and revision. The great increase in available information, which has accelerated since the mid-late 1970s, allows us to highlight here a couple of the most relevant questions in the study of cave art in recent years.

\section{The Documentation of New Cave Art Loci}

In recent decades, there has been a renewed amount of survey and documentation activity, using the latest methods of topography, lighting, recording, image- and information-processing. In addition, there has been (and is) major archeological research throughout the region that clearly contextualizes the cave art found in the same caves that also served as occupation sites (notably at La Viña, Llonín and Tito Bustillo in Asturias, La Garma and El Mirón in Cantabria, Ekain in Euskadi). In some cases (e.g., Viña, Mirón), dated Upper Paleolithic living deposits were banked up against engravings (and in the case of Mirón they also underlie an engraved roof-fall block), providing for terminus ante (and post) 
quem dates and demonstrating the intimate relationship between "mundane" and "artistic" activities in these and many other caves (Fortea, 2000, 2001; González Morales and Straus, 2000; García Diez et al., n.d.). During the last 10 years, in addition to new figures and even new decorated galleries having been found in already-known "art" caves (e.g., La Lloseta-Tito Bustillo, El Pindal, El Pendo, Las Aguas, Pondra, Arco A and B, Arenaza), there have been many discoveries of entirely new sites. To the last regional inventory that had totaled a bit more than 90 decorated caves (González Echegaray and González Sainz, 1994), we can now add 23 more that reasonably can be attributed to the Upper Paleolithic. From West to East and keyed to Fig. 2, these can be listed as follows:

Zone 1-Nalón River Basin: The caves of Santo Adriano (Fortea and Quintanal, 1995) and Torneiros (Fortea et al., 1999), plus other nearby caves with deep engravings of archaic style that were found at the end of 2005 and called, for now, "Cueva Pequeña" and "Camarín de las Ciervas" in the local press ( $L a$ Nueva España, 12/8/05).

Zone 2-Sella River Basin: La Peña de la Morea (Juaneda, 1988).

Zone 3-Deva-Cares Basin: Covaciella (a major locus with polychrome bisons of Altamira style and date) (Fortea et al., 1995) and El Bosque (Fortea, 1995). (No new discoveries in Zone 4, the eastern Asturian coast.)

Zone 5-Nansa River Basin: Abrigo de la Pica (Lasheras et al., 2003, p. 97).

Zone 6-Western Coastal Zone of Cantabria: Cueva de Cualventi (Lasheras et al., 2005).

Zone 7-Pas River Basin: Cueva de Calero II (Muñoz, 2002a).

Zone 8-Miera River Basin: caves of Los Moros de San Vitores (Montes et al., 2001), La Llosa (González Sainz and Cacho, 2002), Peñajorao (Serna, 2002a,b), Morín (Muñoz, 2002b) and the major La Garma Lower and Middle Galleries (González Sainz and Moure, 2002; González Sainz, 2003).

Zone 9-Asón River Basin: caves of Cofresnedo (Ruiz Cobo and Smith, 2003), San Juan de Socueva (Valle, 2002), El Mirón (González Morales and Straus, 2000; García Diez, 2001), La Luz (Montes et al., 2002) and El Rincón.

Zone 10-Easternmost Coastal Zone of Cantabria: caves of Urdiales (Montes et al., 2005) and Los Santos (Serna, 2002b).

Interestingly, these new discoveries are not distributed evenly throughout the length of the region; they are all in the central (Cantabria) and western (Asturias) sectors, with none in the eastern (Basque Country) sector. This reaffirms the strongly asymmetrical distribution of traces of human activity (especially cave art) during the Upper Paleolithic that has always been observed since the beginnings of prehistoric archeological research in northern Spain: dense in the Center and West, scarcer in the East (Fig. 2). This phenomenon is probably a reflection of (among other factors) the more open relief and hence greater economic opportunities for Last Glacial foragers on the relatively broader coastal zones in Cantabria 


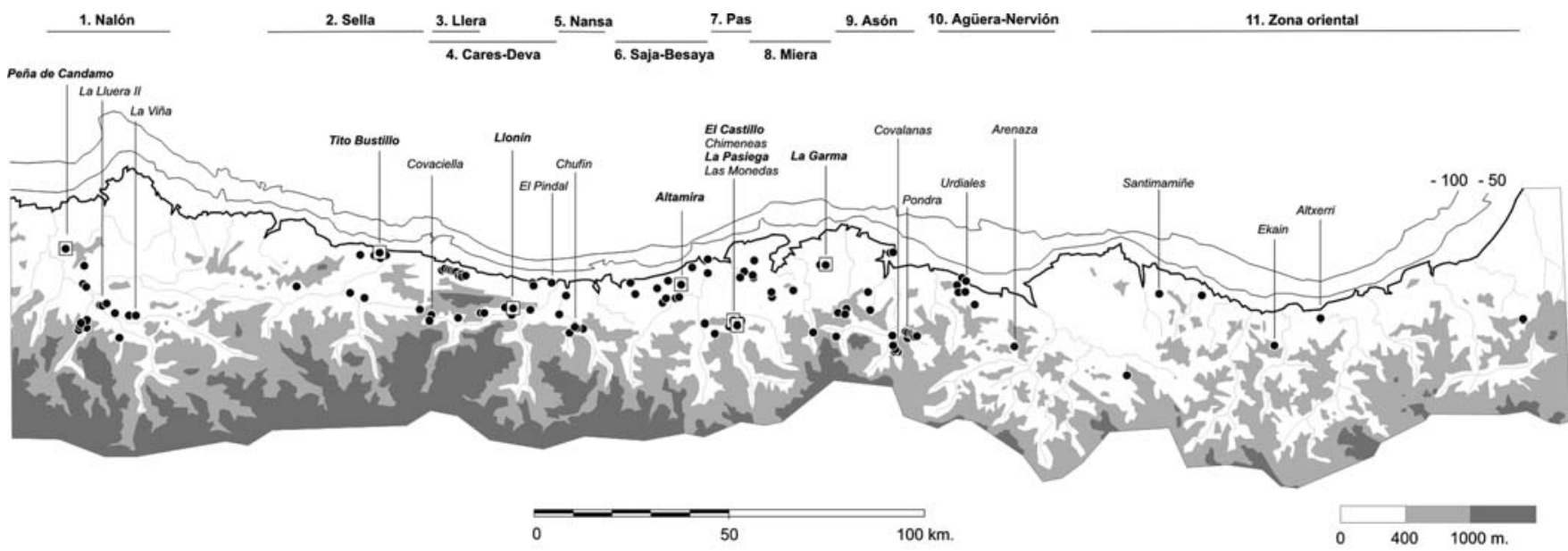

\section{Upper Paleolithic Rock Art in Cantabrian Region (116 caves)}

Fig. 2. Upper Paleolithic Cave art in the Cantabrian Region. The current total number of known loci is 116 decorated caves. Many are simple, but several (especially those individually highlighted here) are quite notable for large numbers of images and wide varieties of expressive techniques and styles, suggestive of longer chronologies of artistic use (C. González Sainz). 
and Asturias, versus the extremely rugged, closed relief of the Basque Country, whose mountains often plunge straight to the sea. The geographic distribution of living sites does tend to even out somewhat during the Last Glacial Interstadial in conjunction with changes in subsistence organization in the Upper Magdalenian (ca. 13-11.5 kya).

Most decorated caves also contain evidence of Upper Paleolithic human habitation and the distributions of cave art and living sites are very similar. There are also clear cases of functional complementarity between neighboring caves, some with better access and major occupation sequences and others with richer graphic records, but scanty occupation residues (e.g., El Polvorín vs. Venta de la Perra and El Rincón, El Mirón vs. Covalanas and La Haza). On the other hand, the increased number of cave art loci has led to the appearance of greater variability. Relative to the corpus available for analysis in the 1970s, the number of "minor sites" (ones with very few representations) has grown disproportionately. Thus, today, there are many ensembles with unintelligible graphic manifestations, such as non-figurative engravings (i.e., simple lines) or spots of red pigment, series of dots or simple marks. This contrasts with the general notion that Upper Paleolithic art is essentially realistic, as well as with traditional documentation that centered on the most complete, complex figures (i.e., those that lend themselves to stylistic analyses and chronological inferences). These simplest motifs are also abundant in the same caves that abound in conventional representations, with variable numbers of animal figures and abstract signs. Some of these sites are currently being studied in detail by various research centers: University of Oviedo (the middle Nalón cluster and Llonín) (Fortea, 2002; Fortea et al., 2004a,b), University of Alcalá de Henares (the lower Sella/Ardines cluster-especially Tito Bustillo and La Lloseta) (Balbín et al., 2003), Altamira Museum (caves of Cualventi, Linar and Las Aguas in western Cantabria), and University of Cantabria (the La Garma karstic complex in central Cantabria) (Arias et al., 1999; González Sainz, 2003). Among the monographs most recently published on Cantabrian cave art are those on the Carranza Gorge sites between Vizcaya and Cantabria (Fig. 3) (González Sainz and San Miguel, 2001), the newly discovered panel in El Pendo (Montes and Sanguino, 2001), Urdiales Cave (Montes et al., 2005), Covalanas (García Diez and Eguizábal, 2003), and syntheses of the caves of the upper Asón (García Diez, 2001) and Vizcaya (Gorrotxategi, 2000). At a different scale of detail, a complete atlas of the decorated caves of the province of Cantabria has been published recently (ADPS, 2002), as well as a multi-media data base of both portable and rupestral art in the whole region (González Sainz et al., 2003) and an archeologically contextualized exhibit catalogue on Cantabrian portable art (Arias and Ontañón, 2005).

There is great variability among the Cantabrian cave art loci in terms of numbers of figures, artistic techniques and expressive modes employed. Although small ensembles dominate, in which there is a certain degree of homogeneity 


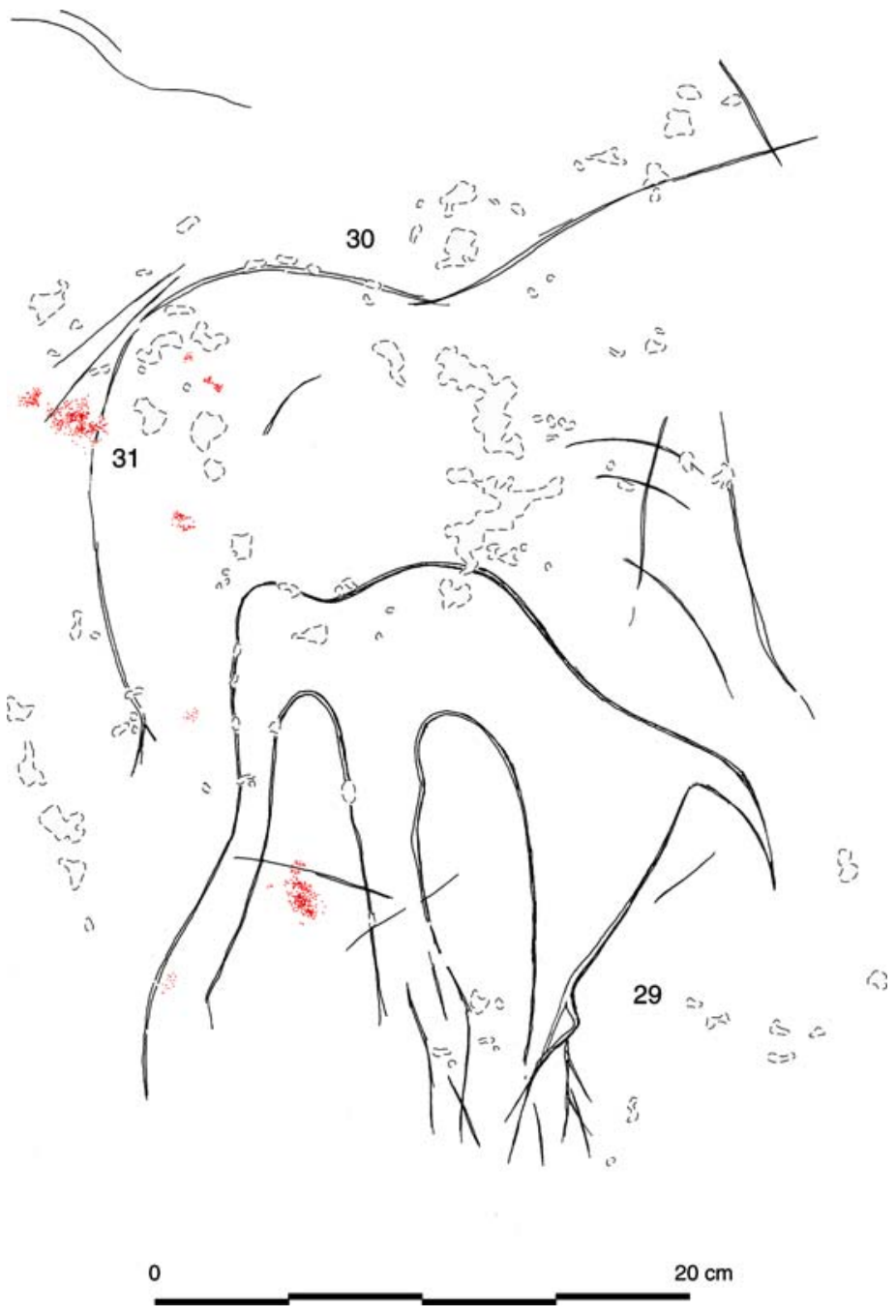

Fig. 3. Engraving of a mammoth in the Cave of Arco B (Carranza Valley, eastern Cantabria) (González Sainz and San Miguel, 2001). The Cantabrian coastal strip was a refugium for Euro-Siberian fauna during the Last Glacial. This fact is reflected in cave art both by the far greater presence of certain ungulate taxa (mammoth, bison, reindeer, giant deer) than in other Peninsular regions and by representational conventions very similar to ones found in cave art of more northerly regions in France (Dordogne, Quercy, Ardèche, Rhône) that are indicative of considerable cultural interaction. The Arco mammoth is a good example of pre-Magdalenian age. 
within each cave in terms of techniques and styles, large, complex sites are more abundant than in other regions of SW Europe (probably due to the relatively high human population concentrated in a very confined region, especially in its central and western sectors (a combined area measuring ca. $225 \times 30 \mathrm{~km}$, with the eastern [Basque] sector adding another $110 \mathrm{~km}$ on the West-East axis). Most spectacular for their large numbers of figures, with many image super-positions and great stylistic diversity, are (from West to East) Peña de Candamo, Tito Bustillo, Llonín, Altamira, El Castillo, La Pasiega, La Garma and Ekain. Most of these are sites that were repeatedly used during different phases of the Upper Paleolithic and in which images on the cave walls accumulated over long periods of time. They were probably significant, enduring centers of reference for the human populations of the region.

\section{Chronometric Dating and Pigment Analysis}

The relative abundance of human occupations and of mobiliary art works have traditionally provided the first indications of the age of the parietal art in individual caves, especially pertaining to the most recent phases of the Upper Paleolithic (Magdalenian). Beyond this, in the past couple of decades, progress has been made in the stratigraphic dating of a few parietal art ensembles, especially in the Nalón Valley (La Lluera II Cave, La Viña Rockshelter) (Fortea, 1994), as well as at El Mirón Cave (González Morales and Straus, 2000; García Diez et al., n.d.). Several others have been dated chronometrically. The application of the AMS ${ }^{14} \mathrm{C}$ method to charcoal pigments in caves in Asturias and Cantabria has provided dozens of dates which provide precision and consistency to the temporal framework for artistic activity during the Middle and Upper Magdalenian at the sites of Covaciella, Altamira, Castillo, Pasiega, Monedas and Garma. At the same time, contradictions have become apparent between radiometric dates and traditional chronologies and the problems of evaluating the results have exceeded initial expectations at the sites of Peña de Candamo, Tito Bustillo, Pindal, Sotarriza and Ekain (Fortea, 2000, 2001, 2002; Fortea et al., 2004a,b; Moure et al., 1996; Moure and González Sainz, 2000; González Sainz, n.d.). A major limitation in the application of the radiocarbon method is the relatively small number of appropriate parietal art images (i.e., drawings made with abundant amounts of charcoal, almost always pertaining to the Magdalenian period). Hence other methods must be used to try to date red (ochre) paintings and engravings. Although still experimental, thermoluminescence has provided dates on calcite films that under- and/or overlie parietal figures of pre-Magdalenian aspect in the caves of Venta de la Perra, Pondra, La Garma and Covalanas in Cantabria (Arias et al., 1998, 99; González Sainz and San Miguel, 2001; Bischoff et al., 2003).

With the chronometric information on rupestral art at hand (combined with detailed comparisons of parietal images to dated mobiliary art objects, as well 
as stratigraphic relationships between parietal art and excavated archeological levels), we can highlight two major conclusions:

1. In the Cantabrian region there is no reason to discard the traditional chronological scheme (i.e., changes in graphic activity along the lines of simple to complex, with increase through time in the technical and formal complexity, in the interest and capacity to represent volume in animal bodies). However there is cause to modify it slightly. The basic idea does seem to have validity as a general tendency toward the development of complexity when one compares representations from the two main temporal subdivisions of the Upper Paleolithic (i.e., the archaic phase corresponding to the Aurignacian, Gravettian and Solutrean periods vs. the recent or Magdalenian phase). But, at the same time, today it is debatable whether one can really sequentially order in the traditional way particular changes in such attributes of the art as location, technical or expressive processes, etc. Synchronic variability in graphic expression was clearly much greater than was traditionally believed. The choice of art location within a cave is no longer a valid indicator of its relative age; among other arguments for this are AMS ${ }^{14} \mathrm{C}$ dates on figures in the inner galleries of Candamo and Calero II, plus TL (at Pondra) and U-series dates in La Garma, which show that there was artistic activity in the deep parts of caves during the archaic phase, as early as the Aurignacian and Gravettian. In regard to techniques, some of the figurative representations done in red pigment that have traditionally been attributed to Leroi-Gourhan's "style III" (supposedly more or less Solutrean in age), may now be moved back to a pre-Solutrean era, thereby expanding the range of time during which techniques typical of this region, such as the red dot outline, were used. Many of these red figures, well- preserved in cave interiors, may have been contemporary with deep engravings done on the walls of cave mouths and solidly attributed — on stratigraphic grounds - to the archaic phase of Cantabrian parietal art Fortea, 1994).

2. During the Magdalenian, in turn, there seems to have been a notably artistic renewal beginning sometime toward the end of the Lower Magdalenian ca. $14.5 \mathrm{kya}$. This is manifested by changes in the fauna most frequently represented and in the "Cantabrian" tradition of abstract signs. There was an "internationalization" of the art, probably as a reflection of greater social interactions with neighboring regions (the French Pyrenees and Aquitaine) that were then also densely populated (e.g., Sieveking, 1979; Sauvet and Wlodarczyk, 2000, 2001; González Sainz, n.d.). This is congruent with the appearance in the Middle Magdalenian of Cantabria and Asturias of such typically "French" portable art objects as cut-out bone ungulate head effigies (contours découpés) and perforated and engraved disks (rondelles) (e.g., Arias and Ontañón, 2005; Schwendler, 2005). 


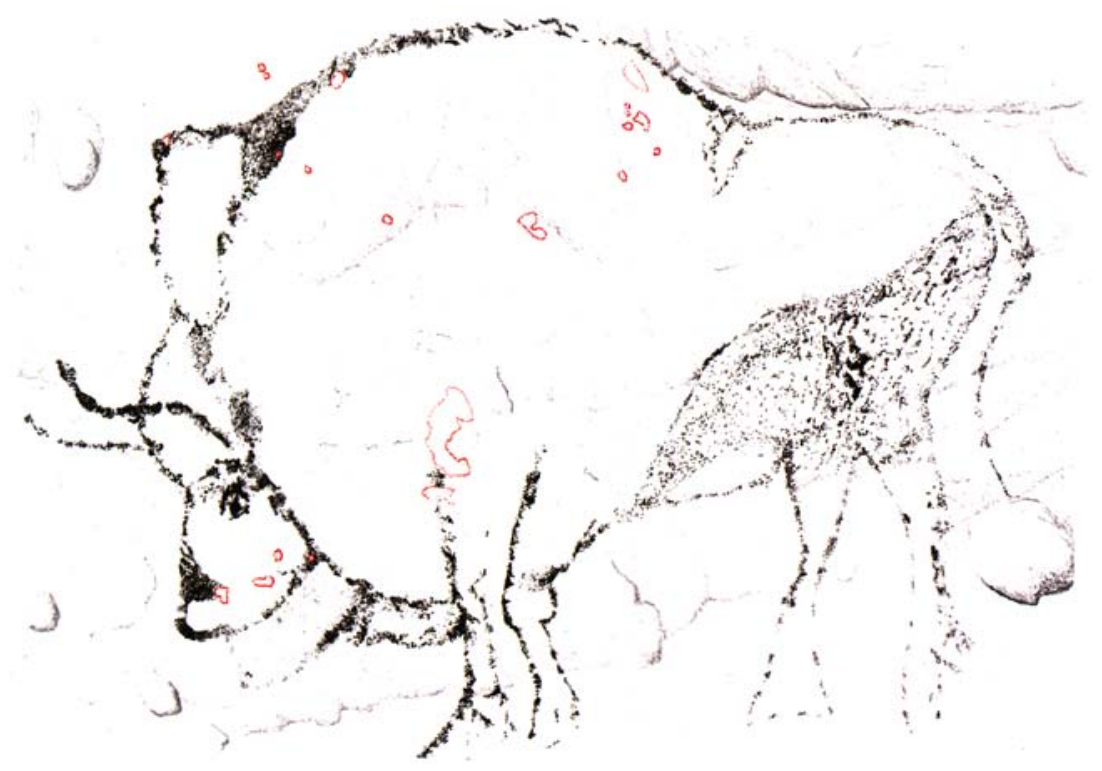

Fig. 4. Urdiales Cave (eastern Cantabria). Representation of a Magdalenian-style bison done with vegetal charcoal, very similar to images in other Cantabrian and Pyrenean caves of this period (after Montes et al., 2005).

In a few sites (Ekain, Tito Bustillo, Pendo, Arenaza, Garma, etc.) pigment analyses have been done (Chalmin et al., 2002; Gárate et al., 2004). The results point to a simpler picture than that which had been painted by the initial pigment studies that had been conducted at sites in southern France. They indicate the frequent use of natural pigments found very close to or even within the caves themselves (Fig. 4).

\section{Final Reflection on the Cantabrian Art Record}

The need to integrate the study of Paleolithic graphic activity with the other components of the cultural system is well established in the research agenda of the Cantabrian region. Parietal (and portable) art is now given an important place in the overall study of the social and territorial organization of Cantabrian huntergatherers and of cultural change during the 30,000 years of the Upper Paleolithic (see Bueno and Balbín, 2001; Straus, 1982, 1987, 1992). However the development of an overarching research focus is still in its infancy, in part because the sheer abundance of new discoveries makes for an archeological record that is in constant growth and change, causing researchers (paradoxically) to have to dedicate their 
efforts to the initial phases of research (excavation, documentation, description) more than to higher-level analysis and synthesis, let alone general interpretation and "explanation".

\section{LEVANTINE SPAIN (VV)}

The Upper Paleolithic of Mediterranean Spain, from Catalonia to Gibraltar, displays a series of characteristics that make it a distinct culture area. The succession and styles of lithic and osseous artifact industries (especially the weaponry), the kinds of adaptations and resource exploitation patterns, as well as the forms of artistic expression, all present numerous elements in common that justify this conclusion. Nonetheless, it is obvious that the great geographic extent of this macro-region implies the existence of smaller territorial units, especially in the later phases when there are clear signs of territorialization. For these reasons, it makes sense in the study of rupestral art to deal with sites in terms of geographic units, while never losing sight of the fact that there are broader regional similarities and that these are based on a still restricted number of art sites, which do not really permit conclusions of a territorial nature. Thus, the differentiation of the Valencian cluster from those of the Southeast or eastern Andalucía is rather arbitrary, for which reason we will mention the existence of notable commonalities. Of extraordinary importance for the systematization of Mediterranean Spanish Paleolithic art is the huge collection of decorated slabs from Parpalló Cave in Valencia (Fortea, 1978; Sanchidrián, 1986; Villaverde, 2005a), so they will be referred to here repeatedly, even though they are portable, not parietal art.

\section{Distribution of Parietal Art Manifestations}

In the large area of Levantine (Eastern) Spain and its neighboring regions, the number of known cave art sites of definite Paleolithic age is rather small: 14 sites distributed among the Aragonese provinces of Huesca and Teruel, the southern Catalonian province of Tarragona, the Valencian provinces of Castellón, Valencia and Alicante, the region of Murcia, and the province of Albacete in La Mancha (Fig. 5). Northern Spanish Catalonia is totally lacking in such sites, which is peculiar given the high density of Upper Paleolithic living sites in Gerona and Lerida just south of the Pyrenees on the one hand, and, on the other hand, the existence in French Catalonia of open-air petroglyphs at Fornols-Haut (Sacchi et al., 1988) and painted signs in Cova Bastera (Abelanet et al., 1984).

In the Ebro River Basin of Huesca is the major cave of Fuente del Trucho with painted dots, hands and horses (Baldellou, 1990; Utrilla, 2000a). Nearby is the site of Chaves Cave with occupation levels containing shouldered points like those of the Salpetrian and late Solutrean industries of Mediterranean France and Spain, overlain by layers with artifacts similar to those of the Upper Magdalenian of the 


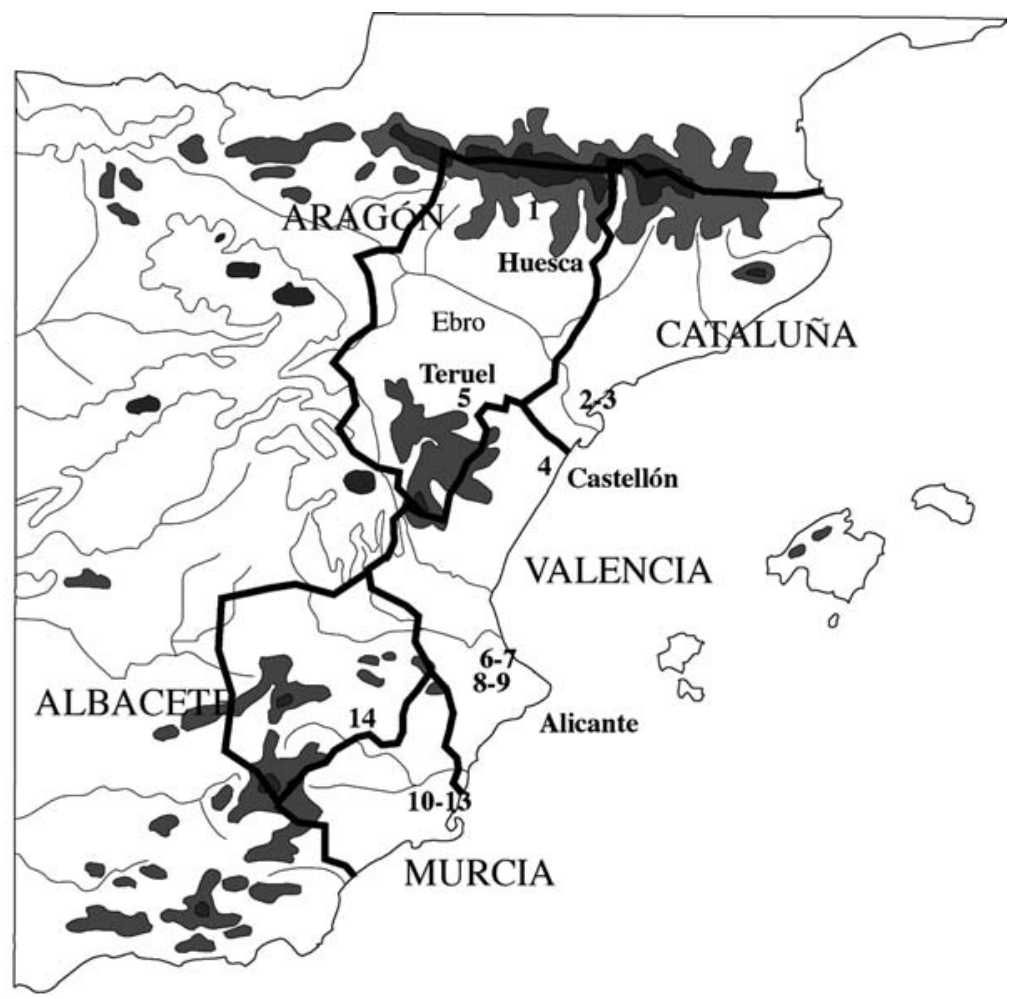

Fig. 5. Upper Paleolithic Cave art of Eastern Mediterranean Spain (Aragón, Catalonia, Levante, Murcia and La Mancha): 1. Fuente del Trucho; 2. Cova de la Taverna; 3. Moleta de Cartagena; 4. Abric d'en Melià; 5. Roca Hernando; 6. Cova del Parpalló; 7. Cova de les Meravelles; 8. Cova Fosca; 9. Cova de Reinós; 10. Cueva de Jorge; 11. Cueva de las Cabras; 12. Complejo del Arco I; 13. Complejo del Arco II; 14. Cueva del Niño (V. Villaverde).

Basque Country in Atlantic Spain (Utrilla, 1990, 2000b). Deep, wide engraved lines in Roca Hernando, further south in the Mijares Basin of Teruel, might be of Paleolithic age (Utrilla et al., 2001). The Ebro Valley probably served as a major communication corridor between the Mediterranean and Atlantic regions during the Paleolithic, as it does today.

In southern Catalonia, near the mouth of the Ebro, are located the two northernmost cave art sites of Mediterranean Spain sensu stricto: Cova de la Taverna, with an engraved red deer that makes partial use of the natural relief (Fullola and Viña, 1988), and Moleta de Cartagena, a now-lost site that had a vertical painted bovine (Ripoll, 1965). This is an area with several Final Paleolithic living sites: Cova del Boix, Abri de Els Cols, Mallada and Molí del Salt (Vaquero, 2004).

In the northern Valencian region (Castellón), less than $70 \mathrm{~km}$ from the abovenamed site cluster, is Abric d'en Melià, where 25 engraved figures have been 
recorded, 11 of which are animals (Martínez et al., 2003). This is the only known group of engravings in a rockshelter. The nearest Upper Paleolithic living site is Cova de Matutano (Olaria, 1999), although the area also has several laminar Epipaleolithic sites, such as Sant Joan de Nepomucé (Fernández et al., 2002).

Much further south, in the province of Valencia itself, in the area where most of the Upper Paleolithic living sites are concentrated (Villaverde et al., 1998), are two other art sites. Cova de les Meravelles, which is still under study, has a panel on which we have identified over a dozen engraved representations of animals, plus some painted dots (Villaverde et al., n.d.). Parpalló (Beltrán, 2002), a site well known for its portable art (Pericot, 1942; Villaverde, 1994a), has also recently (after 80 years of archeological study!) revealed an engraved equid and non-figurative lines, plus remains of paintings. Both sites have occupation deposits (Maravelles: Gravettian, Solutrean and probably Magdalenian; Parpalló: Gravettian, Solutrean and Magdalenian).

These new art finds are added to earlier ones in caves that, although in northern Alicante, are not far away: Covas Fosca and Reinós (Hernández et al., 1988). Fosca has 21 figurative engravings, most on a panel at the rear of the cave, and Reinós has a single painted image of an ibex in its sunlit zone. Fosca has a final Paleolithic living site, while Paleolithic materials have also been found at the mouth of Reinós. Their vicinity is rich in Upper Paleolithic sites, notably Santa Maira (Aura, 2001) and Tossal de la Roca (Cacho et al., 1996, 2001).

Still further south, the next concentration is in Murcia: Cueva de Jorge with an equid painting, Arco with paintings near the cave mouth and a shallow niche also decorated with paintings, and Cueva de las Cabras with figurative paintings (Salmerón and Lomba, 1996; Salmerón et al., 1995). There are only a few, poorly known living sites in this area (Martínez, 1996). Further inland, but connected to the Murcia cluster by the valleys of the Mundo and Segura rivers, is the only known rock art site in Albacete: Cueva del Niño, with several painted animal images (Almagro Gorbea, 1976). Sites with Solutrean and Magdalenian deposits have recently been found in the nearby Sierra del Segura (Córdoba and Vega, 1988; Vega, 1993). All the Levantine prehistoric rock art ensembles, including the Paleolithic ones, have been included on the list of UNESCO World Heritage Sites since 1998, but none are regularly shown to the public, although an archeological park is planned for the area around Parpalló.

\section{A New Situation: The End of the Isolation of the Parpalló Portable Art Collection}

From the time of its excavation at the end of the 1920's, one of the main problems for a real understanding of the portable art of Parpalló had to do with its geographic separation from the cave art concentrations in Vasco-Cantabria, 
southeast France and Andalucía. When Luis Pericot dug the site, the closest-known cave art sites were in Málaga: the long-known loci of La Pileta and Ardales. The distance from those sites and the lack of any geographically intermediate ones help explain why the Parpalló slabs were even considered substitutes for parietal art in the central sector of the Iberian Mediterranean region. Contributing to this idea were the facts that a large number of the slabs are painted and the themes have a clear parietal conception, especially in the early periods, with the inclusion of signs that are common to cave art, such as dots and rectangles.

Although cave art sites with multiple animal images are still relatively few in the Levantine region, the present situation is far different from that of the 1930-1940s. Only Meravelles, Melià and Fosca have more than a dozen complete or partial animal representations, but no site has as many as 20. In contrast, for example, the Málaga sites of Ardales, Pileta and Nerja have more than 90, about 50 and more than 30 images respectively. Despite this fact, which serves to define the most frequent type of art sites in Mediterranean Spain (even in Andalucía) namely ones with few representations - the number of art loci really has increased notably in the last two decades, confirming that this too was a region where both portable and rupestral art coexisted in the Upper Paleolithic. This was true even within the same nearby sites: Parpalló and Meravelles. This leads one to think that the high degree of skill manifested by the Parpalló engraved slabs can only be understood in light of well-established regional artistic traditions, which must have been involved in the creation of many more rock art figures that are either yet to be found or are now destroyed.

Comparison between the engravings of Meravelles and those of the Parpalló slabs is very suggestive in terms of confirming that criteria of stylistic change established with the collection from the latter site (Villaverde, 1994) may also be relevant to the study of parietal art. Preliminary comparison of the style of the horse image engraved on a wall of Parpalló with the identified figures from Meravelles confirms the similarity of the graphic conceptions of these representations to those on slabs from the early Solutrean of Parpalló and allows us to extrapolate chronological conclusions derived from the portable art collection to the parietal art of the region. This method has also been established for cave art sites in Andalucía (Fortea, 1978; Sanchidrián, 1990, 1994a,b).

\section{The Importance of Novelties: The Variety of Site Locations and Chronological Longevity}

Two aspects stand out in the relatively small inventory of currently known sites. First is the diversity of settings in which the parietal art images are found. There are some fairly deep caves, such as Fosca, whose main art panel is $70 \mathrm{~m}$ from the mouth, Taverna, whose only representation is $100 \mathrm{~m}$ from the mouth, some of the figures in Niño, or Meravelles, with a panel only $10 \mathrm{~m}$ from the 
entrance, but in an area which is nonetheless outside the sunlit zone of the cave. A similar situation exists in Cabras, with figures located near the mouth, but forming a panel which is back-lit such that a strong artificial light source is needed to see it during daytime. In contrast, there are very shallow caves in which the figures can easily be seen with sunlight, as in the cases of Parpalló, Reinós, Jorge, the main panel of Niño, or the figures of Arco I. Finally, there are also some images which are found in unusual settings and others where preservation is precarious. Such are the cases of Arco II, with a panel in a small rockshelter, or Melià, a rockshelter with a slight overhang which leaves the engravings exposed to the elements.

This kind of diversity of parietal settings has long been observed in other regions and thus is not something peculiar to the Mediterranean area. On the contrary, it informs us about a diverse artistic creativity relative to the kinds of places that were chosen to decorate, which makes sense in terms of a phenomenon (art) which was present in all aspects of daily life, from those that took place in the dark interior of caves to those that occurred in the mouths or even in the open air, where rockshelter wall art could have served a territorial marking function. In any event, the kinds of limestones on which the paintings of Arco II and the engravings of Melià were made serve to warn us about the problems of conservation that can affect these kinds of images when exposed to degradation by natural agents and about the need to pay more attention to such rockshelters in future surveys. The differential preservation problems may have created a partial vision of the original distribution of Paleolithic rock art in the Mediterranean region.

The chronological longevity of Paleolithic art in Mediterranean Spain is also noteworthy, although the limited number of sites and the very small number of direct dates for representations-the majority of which are engravings-have made it impossible to establish a precise chronological framework for most of the region's parietal art. However, some aspects do mitigate this problem and give us an idea of the time-depth of Mediterranean Paleolithic art.

For the early end of the timescale, we have evidence among the portable art collections from Parpalló and nearby Malladetes. In both caves there are figurative representations from Gravettian deposits that lend themselves to comparisons with some parietal figures attributable to this period in Andalucía. The Gravettian engraved slabs from these two sites have aurochs figures that share a common graphic canon: incomplete representations with clear interest in the anterior part of the body; small heads relative to the rest of the body, with a tendency toward a narrowing of the muzzle and horns, which are straight and forward-pointing; cervico-dorsal lines, which are rectilinear; poor articulation of the chest and anterior body with the ventral line producing a "strangulation" of the anterior part of the flank; and scant attention to representation of the limbs (Fig. 5). 
It is interesting to relate this graphic phase with a red outline drawing of an aurochs in inverted vertical position in the cave of Ardales (Málaga), which is associated with the hand print phase (Cantalejo et al., 2004; Fortea, 2005), and to consider that, as in other Iberian regions, there definitely was a Gravettian period of parietal art, just as there was portable art at this time in Parpalló and Malladetes (Villaverde, 2005). This conclusion is coherent with what is being found all over the Peninsula and because of the increasing numbers of discoveries of Gravettian living sites in the Mediterranean region, with radiocarbon dates ranging between 26-21,000 BP (Villaverde and Roman, 2004; Fullola, n.d.). Perhaps belonging to the same period (or to the immediately succeeding Solutrean) are the many hand prints in Fuente del Trucho (Aragón).

Clearly, there are many parietal figures in the Mediterranean region that have graphic conceptions easily attributable to the various stages of the Solutrean, although among the slabs of Parpalló there is not a clear-cut distinction between the art of the Gravettian and that of the earliest Solutrean, such that-in the absence of ${ }^{14} \mathrm{C}$ dates for this transitional period-it is wiser not to attempt to precisely distinguish the two periods. However the art of the Upper Solutrean is clearly differentiated and defined in comparison to the earlier phase in the Parpalló collection (Fig. 6).

At the other chronological extreme of the Upper Paleolithic are the engravings of Melià, for which we suggest an age corresponding to the transition to the Epipaleolithic (Pleistocene-Holocene boundary). In this case, the stylistic parallels that support the hypothesis come both from the Parpalló collection and from works of portable art from living sites in the geographic vicinity of the parietal art site in question, namely the images form Matutano, Sant Gregori and Moli del Salt. In between the Solutrean and the Epipaleolithic there is an interesting, albeit complex and problematic phenomenon: the apparent relative scarcity of Magdalenian art in the Mediterranean region, a fact which is even more notable in Andalucía. Of possible relevance to understanding this phenomenon might be the peculiar development of art in this region and the application of excessively rigid, simplistic criteria for the determination of style and chronology among parietal representations. At this time, the few figures that might be Magdalenian in age are the engraved horse in Taverna, the engravings of Fosca, some images in Niño, Cabras and Arco. In the specific case of Fosca (Fig. 7), despite the simplicity of the lines and the general lack of details in the animal figures, there is a co-occurrence of elements which, in our opinion, support the hypothesis of Magdalenian age: the dominance of closed heads, with respect to both muzzles and foreheads, the existence of well-proportioned bodies showing limbs in absolute profile view, the appearance of lineal $\mathrm{V}$ ears among the red deer hinds, the drawing of ear details and showing linear aurochs horns with a subtle S-stroke (Villaverde, 2005). All these traits are comparable to images on slabs found in Magdalenian levels at Parpalló. 

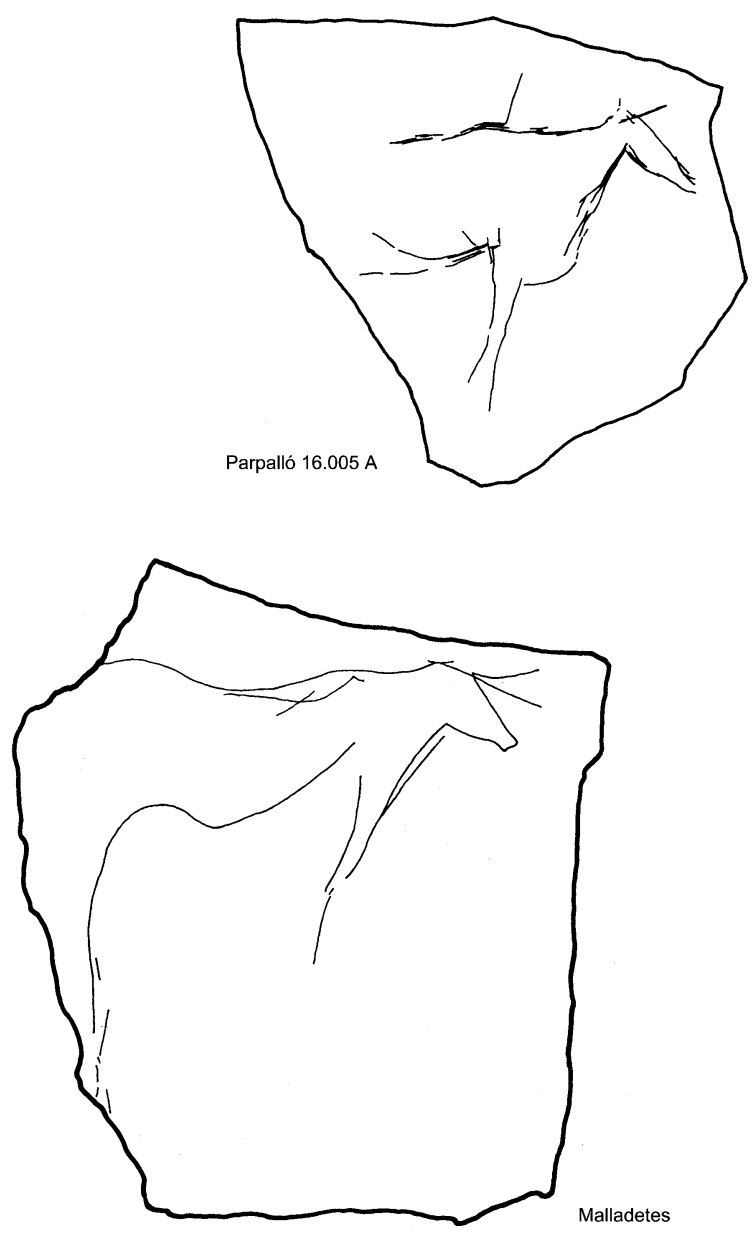

Fig. 6. Representations of aurochsen on Gravettian slabs from the Caves of Malladetes and Parpalló (V. Villaverde).

\section{The Importance of Solutrean Art and Its Continuity with Respect to the Gravettian Stage}

The most interesting aspect of Paleolithic art in the Mediterranean region is the abundance of loci that pertain to the Solutrean period during the Last Glacial Maximum. The portable art collection from Parpalló includes 2,481 slabs with 386 zoomorphic representations that date to this time, thereby providing a clear chronological referent for stylistically similar parietal art images no only in the region of Valencia, but also in those of Murcia and Andalucía. The art from the 


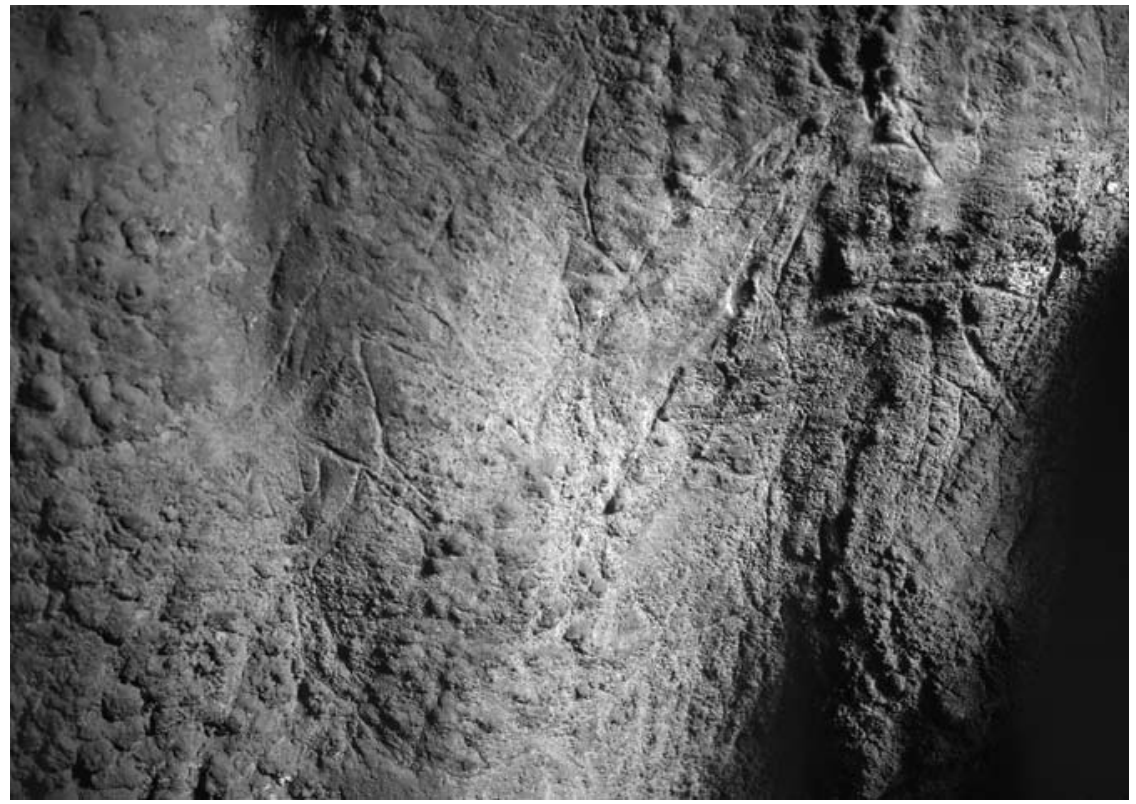

Fig. 7. Central panel of Cova Fosca: detail of the lower cluster of images (V.Villaverde).

somewhat more than $3 \mathrm{~m}$ of Solutrean deposits in Parpalló can be divided between two big phases: early (including the Lower and Middle Solutrean, as defined by artifacts) and late (including the Upper and Final Solutrean) (Villaverde, 1994a,b). Many Andalusian parietal art ensembles have been related to these phases by means of careful comparisons with the sequence of Parpalló decorated slabs (Sanchidrián, 1994a,b), and, in turn, the direct ${ }^{14} \mathrm{C}$ dates of ca. 20 kya on charcoal drawings in La Pileta and Nerja (Málaga, Andalucía) (Sanchidrián et al., 2001) confirm that the stylistic criteria used in these comparisons are indeed valid.

The two recent discoveries of parietal art in southern Valencia Province have provided further evidence for the Solutrean age of much art in the Mediterranean region. In fact, in the case of Parpalló it is possible to establish a relationship between the recently discovered horse engraving (Beltrán, 2002) and the archeological deposit in the same cave (Villaverde, 2004). The height of the figure suggests that it was made when the occupation surface was at the level of the Lower or, more likely, Middle Solutrean, ca. 21-19 kya. The image was ultimately covered over in part by sediments dating to the Upper Solutrean, 18-17 kya. The other site, Meravelles has yielded TL dates done by the Autonomous University of Madrid on calcites both over- and under-lying the engravings: the former are 18,849 \pm 3023 and $18,106 \pm 2534 \mathrm{BP}$ and the latter is $32,735 \pm 3857 \mathrm{BP}$. These terminus ante 
and post quem dates for the art are perfectly compatible with the Solutrean age to which we have assigned the engravings on stylistic grounds (Fig. 8).

Both the parietal art in Parpalló and many engravings in Meravelles are characterized by stylistic characteristics easily attributable to the early phase of portable art in Parpalló: animals with disproportionately small heads relative to the bodies; long, narrow necks on massive bodies (especially the hindquarters), but without excessive curvature in the dorsal area; incomplete extremities lacking in details and convex bellies; rather forced articulation between the fore-limbs and the chest line, a fact which causes the typical "strangled" appearance of the figures. The simplicity and slight modeling of the lines, with long faces and narrow muzzles in the cases of the ibex and aurochsen, and with a kind of image construction dominated by a curved, concave character of the lines defining the face and a convex jaw, all constitute the most distinctive traits of the figures which we include in the first stage of engravings on the main panel at Meravelles.

For their part, the figures that we attribute to the late Solutrean phase also duplicate the usual formulas found among the Parpalló slabs. There are aurochsen with horns shown in twisted perspective, detailed representation of the ears and elongated faces, but closed mouths. The horses have manes that are stepped relative to the forehead line and better-proportioned bodies, with greater detail at points of anatomical inflection (Villaverde et al., n.d.).

These data not only confirm the importance of Solutrean parietal art and permit us to affirm the validity of stylistic criteria derived from the analysis of the Parpalló portable art sequence used for dating rupestral art, but they also suggest significant continuity between Gravettian and early Solutrean art. This latter point is particularly important, since it implies the existence of an evolving local artistic tradition in this region, as is also true of the lithic industries of the so-called Iberian facies of the Solutrean. Gravettian influences are also apparent in more northerly regions. Specifically we think that, while the early phase of Solutrean art in the Mediterranean region could have been the result of the expansion throughout the Franco-Iberian region of Solutrean industries with bifacial invasive retouch, the evolved phase could have been the upshot of the spread of backed shouldered points, with clear relationships to the record in SE France. However the evolved Solutrean art also presents undoubted similarities to that of the Cantabrian region with regard to such traits as rectangular signs and the way in which are drawn horse heads, to only mention some of the most distinctive attributes. The position of Fuente del Trucho, geographically intermediate between the Mediterranean and Cantabrian regions in the Ebro Basin, can help explain undeniable evidence of contacts, for example by means of decorations on single-bevel sagaies which are present at the end of the Mediterranean Solutrean and at the beginning of the Cantabrian Magdalenian, which both date to around 17 kya. Long-distance contacts must have characterized the late Solutrean world, just as in later periods, although these may have been along different geographical axes. These contacts 


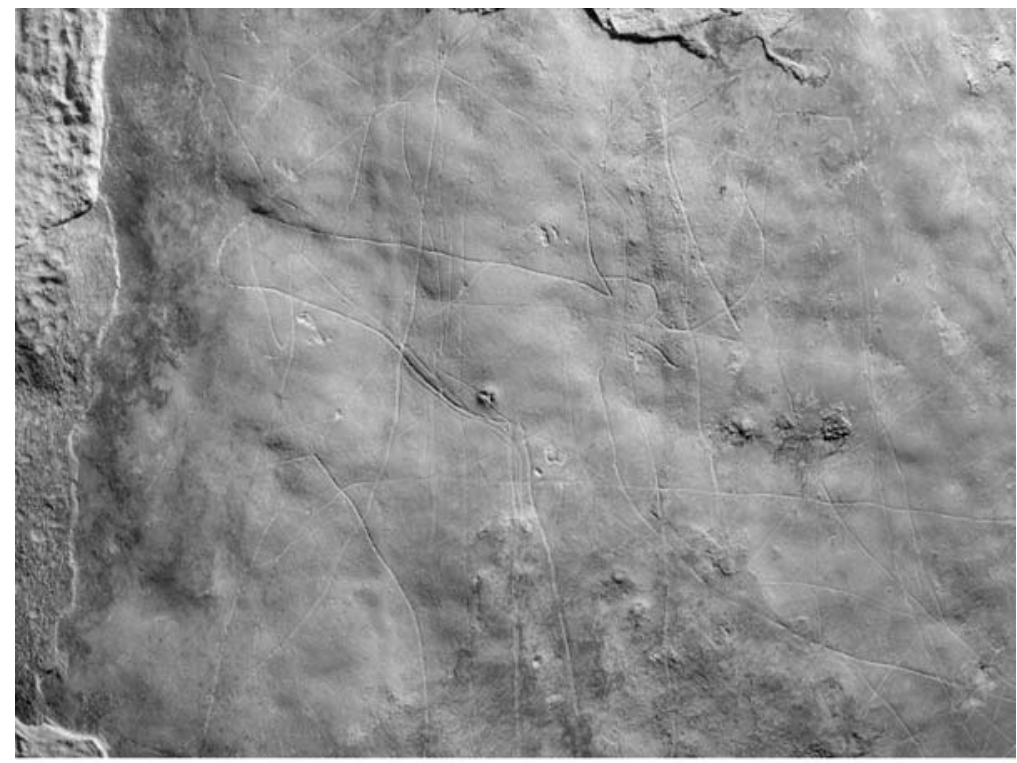

(a)

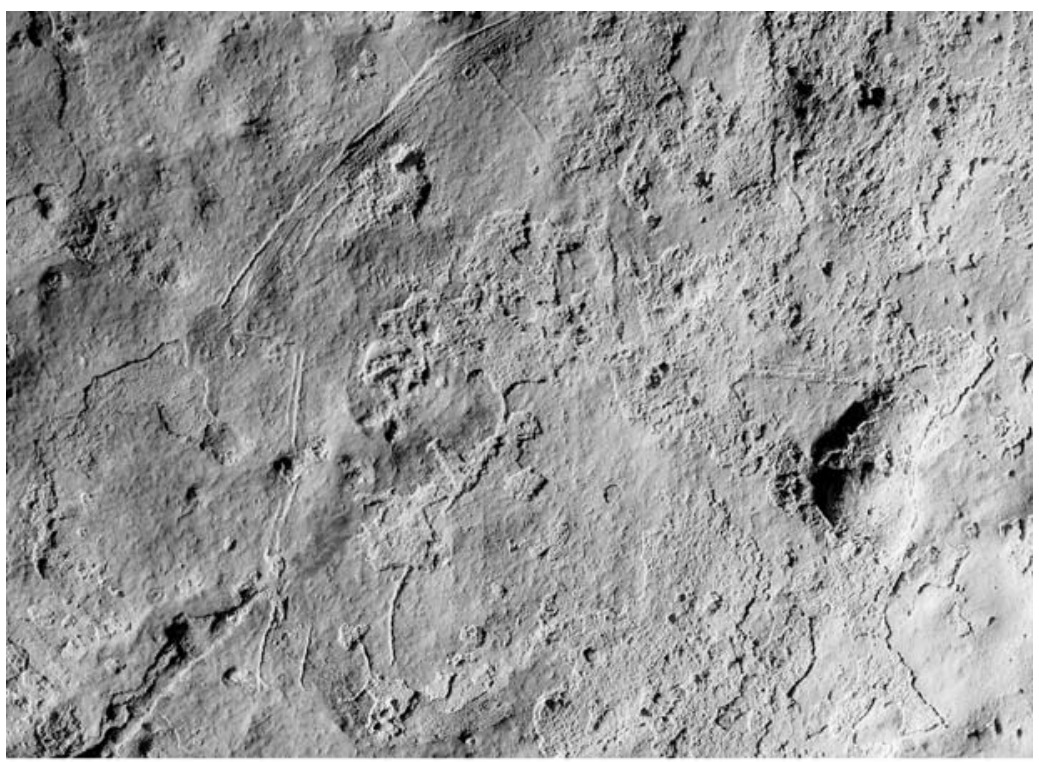

(b)

Fig. 8. Cova de les Meravelles (V. Villaverde). (a) Aurochs image made with repeated and multiple engraved lines, superimposed on other figures and lines. (b) Horse image made with simple and multiple lines, showing particular detail of the nostril and mouth, and a stepped mane. 
help explain the similarities that clearly exist between the Middle Magdalenian of the French Pyrenees and the Cantabrian region.

In order to correctly understand pre-Magdalenian art, it is important to emphasize that most of the parietal art in the Mediterranean region, from the Valencian cluster of Parpalló, Meravelles and Reinós to the Andalusian one, by way of the Murcia-Albacete sites of Jorge and Niño, can be attributed to the early or late Solutrean. This is also likely true of Fuente del Trucho. It is reasonable to think that this situation could be the consequence of a concentration of human populations in southerly areas during the Last Glacial Maximum. At this time, the refugium of the Iberian Peninsula was a major center of European Paleolithic art.

\section{Art of the Spanish Mediterranean Region versus Art of a Mediterranean Artistic Province}

The bibliography on Paleolithic art reflects the great influence of a proposal made 40-50 years ago by Graziosi $(1956,1964)$, when during his study of the European record he established the notion of two large artistic provinces: the Franco-Cantabrian and the Mediterranean. The consequence of this proposal has been that, years later and with an art record very different from that which existed at the time, many researchers are still considering the Spanish Mediterranean region as marginal with respect to the Franco-Cantabrian core area. And they still see the former as being part of a broader Mediterranean world of Paleolithic art, notably including that of Italy.

The vision that we have today, both of industrial sequences and of Paleolithic art in Mediterranean Spain, SE France and Italy, is very different and in no way justifies maintenance of a generic "Mediterranean Basin" view as proposed by Graziosi. The Upper Paleolithic of the Spanish Mediterranean has a sequence which is clearly different from that of Italy. The links that the Spanish Mediterranean had were clearly with the Cantabrian and southern French regions, there being correlations in terms of cultural changes reflected in the lithic and osseous industries, as well as in artistic expression. The number of sites that have yielded portable and parietal art is much greater than it was in the 1950s both in Mediterranean Spain and in Italy, and most recent research has been cognizant of the new situation (e.g., d'Errico and Possenti, 1999; Mussi, 2001; Villaverde, 2004, 2005b; Zampetti and Mussi, 1999). It makes no sense to continue to group Spanish Mediterranean and Italian art together in contrast to Franco-Cantabrian art. Even the criteria on which the ideal of a link among the art of Parpalló, Pileta and Romanelli (in Italy) had been built has ceased to have a consistent basis. Italian Paleolithic art presents evidence of marked regionalization, especially in its later stages after ca. 17,000 BP. Its relationships are established-as in the case of Mediterranean Spain—with immediately adjacent areas, i.e., SE France and 
the Adriatic shores, but there is no way in which its southern zone could have had a direct relationship with the south-central area of Iberia. On the contrary, in the south of Italy art styles became increasingly distinctive and were even unlike those of Mediterranean France in the Magdalenian. The unique development of the Upper Magdalenian in the Mediterranean region of Spain resulted in a form of Epimagdalenian known as the microlaminar Epipaleolithic of early Holocene age (Fortea, 1973), with virtually no trace of so-called the "Azilianization" process so typical of the Atlantic facade of Europe. The graphic images of the final Magdalenian of Mediterranean Spain display a combination of a regional tradition as reified in the modes of representation of animals and in the form of the signs on the one hand, and, on the other, the kinds of changes that were also taking place in other regions of southern Europe. Thus, although with different solutions, the final stages of the Paleolithic art cycle witness the same trends toward simplification, geometric designs, and a lack of proportionality which one can also see in Final Magdalenian and Azilian art of southern France-in the Périgord, Lot or Languedoc.

Recent finds in Melià Rockshelter confirm this phenomenon and clearly show a lack of common elements at the end of the Paleolithic art cycle between Mediterranean Spain and southern Italy. The parallels to these parietal representations in portable art are clearly found among engraved objects from the terminal Magdalenian levels of Sant Gregori, Moli del Salt, Tossal de la Roca and Parpalló (García, 2004; Villaverde, 2005). The lack of stratigraphic precision for many of the slabs from the upper part of the Parpalló sequence had until recently prevented us from specifying developmental tendencies within this last Paleolithic art, but the new finds clearly allow us to highlight differences from Graziosi's supposedly diagnostic traits for his Mediterranean art province, especially when we take into account the defining characteristics of the now more abundant art of southern Italy and Sicily. This situation necessarily differentiates the art of Mediterranean Spain from that of Italy-known there as "Mediterranean style" (Palma di Cesnola, 2001; Graziosi, 1973).

The process of regionalization that characterizes Magdalenian art in general also has an undoubted corollary in the Adriatic world that is derived from the Italian Peninsula. In the future it will be necessary to continue this line of research to really understand Paleolithic graphic imagery in relationship to the territorial dimension of human groups. To do otherwise would be to undervalue the complex territorial reality that characterized the end of glacial times in Europe.

With regard to the Iberian Peninsula per se, the Mediterranean region shows itself to have constituted a territorial entity with clear common elements and traits that distinguished it from other regions of the Peninsula. This does not take away from the fact that, logically, the greatest similarities were with the closest regions. The widespread nature of the Iberian facies Solutrean (with stemmed and 
backed shouldered points) makes it possible to explain, for example, the existence of contacts throughout the southern regions of Spain and even with Portugal. However, a relative lack of knowledge of the Upper Paleolithic in the tablelands (mesetas) currently complicates our ability to establish evidence for relationships between the coastal areas of the Peninsula across the interior of Spain. Nonetheless, one can note that the parietal and portable art representations of the Central and Iberian Mountain chains, as well as those of the Ebro Valley seem to show closer relationships to the Cantabrian world than to the Mediterranean one, at least at the Magdalenian end of the sequence.

\section{THE SOUTHERN END OF SPAIN: ANDALUCÍA AND EXTREMADURA (JLS)}

\section{Site Inventory and Geographic Distribution}

Two dozen Paleolithic rock art sites are currently known from Andalucía and Extremadura, and a few more are under study (Sanchidrián, 2000a; Ripoll et al., 1999; Cantalejo et al., 2006; Collado et al., 2003, personal communication) (Fig. 9). To complete the record of Paleolithic artistic expression, one could add other sites which have yielded mobile art objects: the engraved cobbles and slabs of Solutrean age at Ambrosio (Almería), Bajondillo and Nerja (Málaga), as well as engraved bones and stones of Magdalenian age in Nerja, Pirulejo (Córdoba) and Malalmuerzo (Granada). (Two supposed cases of cave art in Gibraltar are controversial and problematic.)

Table I lists the rock art sites of Andalucía and Extremadura (provinces of Cáceres and Badajoz), giving for each its provincial location, type of site (cave, rockshelter, open-air), chrono-cultural attribution, and any indications of Paleolithic cultural remains either at the site itself or in its vicinity (within a stated distance or within a territory defined by a radius of ca. $10 \mathrm{~km}$ of the art site). The first thing to note is that this geographic distribution of rupestral art loci does not correspond to a clear spatial pattern of human occupation of the landscape, to a marking or "appropriation" of the territory, since in general rupestral art sites continue to appear as a result of accidental discoveries, thereby filling the geographical gaps. Nonetheless it is obvious that the rock art sites are not distributed throughout this vast region without being clustered and without evidence of living sites, as used to be the case a few years ago. As shown by the table, a large number of decorated caves are directly associated with (or at least lie within $1 \mathrm{~km}$ of) a relevant archeological site, and the rest are within at most about a 2-h walk of living sites. Territorial organization seems to be structured by river valleys as means of communication and by coastal zones, which during the coldest times and as a consequence of marine regression, were widened by about 


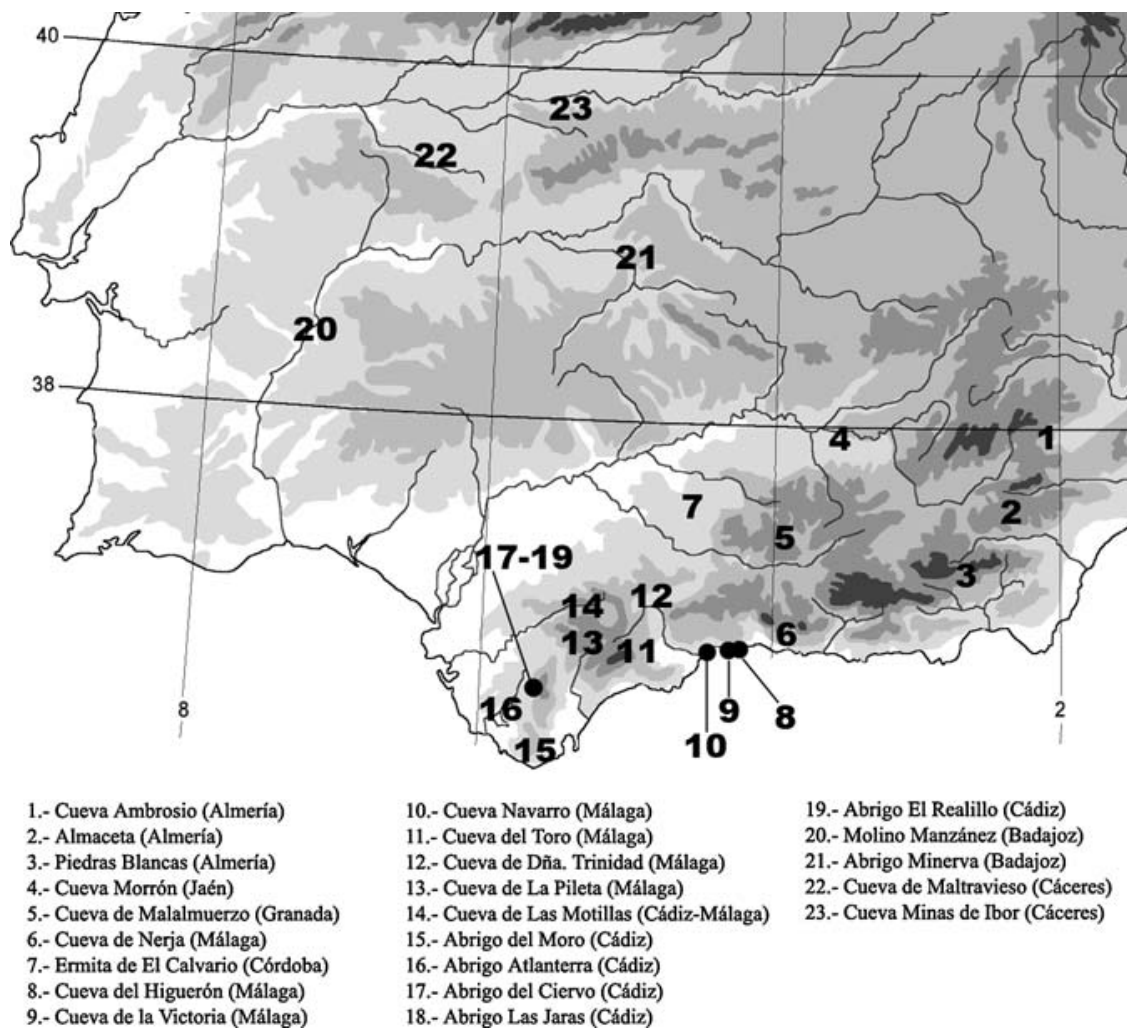

Fig. 9. Upper Paleolithic Cave, Rockshelter and Open-Air Rock art of Andalucía and Spanish Extremadura (J. L. Sanchidrián).

$10 \mathrm{~km}$ of then dry land along the Mediterranean coast and about $30 \mathrm{~km}$ along the Atlantic shore. The existence of rock art associated with nearby living sites clearly reflects a coherent organization of territories as would be expected of groups of hunter-gatherer-fishers in the Upper Paleolithic, although obviously more detailed documentation is needed on absolute chronology, site functions, seasonality, etc., in order to fully reconstruct the settlement-subsistence systems at different times during this long period in this large, geographically complex region.

\section{Cultural Associations and Chronology}

With respect to the artifactual evidence, although it is the case that the record is still in its early stages of development in southern Spain relative to the Cantabrian or even Levantine regions, we do have enough information to 
Table I. Rock Art Sites of Andalucia and Spanish Extremadura

\begin{tabular}{|c|c|c|c|c|}
\hline Site & Province & Type & Cultural Phase(s) & U.P. Artifacts \\
\hline Ambrosio & Almería & Rockshelter & Solutrean & At the site \\
\hline Almaceta & Almería & Cave & Solutrean & Within $10 \mathrm{~km}$ \\
\hline Piedras Blancas & Almería & Open-air & Solutrean & Within $10 \mathrm{~km}$ \\
\hline Malalmuerzo & Granada & Cave & Solutrean & At the site \\
\hline Morrón & Jaén & Cave & Solutrean & Within $10 \mathrm{~km}$ \\
\hline Nerja & Málaga & Cave & Solutrean and Magdalenian & At the site \\
\hline Higuerón & Málaga & Cave & Solutrean and Magdalenian & At the site \\
\hline Victoria & Málaga & Cave & Solutrean & Within $1 \mathrm{~km}$ \\
\hline Navarro & Málaga & Cave & Solutrean & At the site \\
\hline Toro & Málaga & Cave & Solutrean & Within $1 \mathrm{~km}$ \\
\hline Doña Trinidad de Ardales & Málaga & Cave & Gravettian and Solutrean & At the site \\
\hline La Pileta & Málaga & Cave & $\begin{array}{l}\text { Gravettian, Solutrean and } \\
\text { Magdalenian }\end{array}$ & Within $10 \mathrm{~km}$ \\
\hline Moro & Cádiz & Rockshelter & Solutrean & Within $1 \mathrm{~km}$ \\
\hline Motillas & Cádiz & Cave & Solutrean & At the site \\
\hline Atlanterra & Cádiz & Rockshelter & Solutrean & Within $10 \mathrm{~km}$ \\
\hline Ciervo & Cádiz & Rockshelter & Solutrean & Within $10 \mathrm{~km}$ \\
\hline La Jara & Cádiz & Rockshelter & Solutrean & Within $10 \mathrm{~km}$ \\
\hline El Realillo & Cádiz & Rockshelter & Solutrean & Within $10 \mathrm{~km}$ \\
\hline Ermita Calvario & Córdoba & Cave & Magdalenian? & Within $10 \mathrm{~km}$ \\
\hline Maltravieso & Cáceres & Cave & Gravettian & - \\
\hline Minas de Ibor & Cáceres & Cave & Solutrean and Magdalenian? & - \\
\hline Minerva & Badajoz & Rockshelter & Magdalenian? & - \\
\hline Area of Molino Manánez & Badajoz & Open-air & Solutrean and Magdalenian & - \\
\hline
\end{tabular}

provide context and to relate works of art to territorial settlement patterns and techno-complexes characteristic of different periods. After a long period during which southern Spain was abundantly populated by Neandertals with their Middle Paleolithic technology, they were tardily replaced by anatomically modern humans with Upper Paleolithic technologies at around 30 kya, although this substitution may have occurred a bit earlier at the Cave of Bajondillo (Torremolinos, Málaga). Thus, both the Aurignacian (very rare) and the Gravettian (more abundant) have been found in their traditional chronological positions in Andalucía, namely in its SE corner: Málaga. It is with the Solutrean, however, that there seems to have been a real explosion in the number of sites with characteristic projectile points in this southwesternmost region of Europe, which Straus (2002, p. 49) has characterized as a "refuge within a refugium". Finally the Upper Magdalenian with harpoons is being found in an ever-larger area, not just along the coast of Málaga and Murcia, but also in the interior up into the Subbetic Hills, with the site of Pirulejo in Priego de Córdoba.

Stratigraphic seriations are most completely represented in the deposits of the caves of Bajondillo, Nerja, Ambrosio and Pirulejo. The first site has a sequence that begins with several Mousterian strata overlain by a well-dated series of Upper Paleolithic levels: Aurignacian (ca. 34-32 kya), Gravettian (ca. 26-22 kya), Middle Solutrean (ca. 21-18 kya) and a clear Final Solutrean (Baldomero et al., 2005). 
Nerja began its sedimentary in-filling with the late Gravettian dated between 2321 kya, continuing through a series of Solutrean levels (ca. 18-16 kya) and three layers of Upper Magdalenian up to around $12 \mathrm{kya}$, followed finally by several Epipaleolithic, Neolithic and later Holocene occupations (Aura et al., 1998). The sequences of Bajondillo and Nerja, located at opposite ends of the Bay of Málaga overlap and complement one another, while those of Ambrosio (Ripoll, 1998) and Pirulejo, help to highlight the singularities and development of the Andalusian Solutrean and of the Magdalenian "epilogue" respectively.

On the other hand, from both quantitative and qualitative standpoints, the great art site par excellence of the whole region continues to be La Pileta Cave, which contains 872 Paleolithic figures of different periods, followed by Nerja with more than 500 and the Cave of Doña Trinidad de Ardales with a similar number. The rest of the rock art loci are far more modest, since, with the exception of the caves of Navarro, Maltravieso and Malalmuerzo with about 100 figures each, the usual number is no more than at most 10 per site. Indeed the sites of Cádiz Province, on the Atlantic side of Andalucía, "normally" have only one animal image each.

\section{Site Types}

It is interesting to analyze the kinds of places which were chosen for decoration, since most of the Andalusian sites do not conform to the widespread notion that most Paleolithic art loci are in the dark, deep interior of caves. A simple empirical classification of the rock surfaces used for decoration by the Paleolithic artists in southernmost Spain shows the following:

1. large, deep caves with difficult access (e.g., La Pileta, Nerja, Motillas);

2. short, "easy" caves (e.g., Morrón, Victoria, Navarro, Maltravieso, Minas de Ibor);

3. exposed rockshelters (e.g., Ambrosio, Moro, Atlanterra);

4. open-air outcrops (e.g., Piedras Blancas, Molino Manzánez on the Spanish side of the Alqueva reservoir).

This great diversity of decorated surfaces may probably be informing us about marked functional diversity among the art loci or about the diverse motivations of the artists. Some works of rupestral art can be directly seen under sunlight, as among the completely exposed rock outcrops of Côa in Portugal or in barely protected rockshelters or cliff overhangs such as at Piedras Blancas or Ambrosio in Andalucía. On the contrary, a significant portion of the Paleolithic images of the region are found in karstic cavities with varying degrees of depth, requiring the use of artificial lighting both to create and to view them. Some are quite short and simple as caves, but others are very large and/or complicated, with many galleries (Pileta, Ardales, Nerja). This last group, from a temporal perspective seems to 
include places that maintained their significance over the long-term since they were used repeatedly throughout the Upper Paleolithic, thus perhaps serving as places "hallowed" by a long emblematic or symbolic tradition. In contrast, the rest of the decorated loci simply contain images pertaining to single periods, usually Solutrean-suggesting short episodes of human use or "meaning".

On the other hand, our chronological frameworks and seriations of the $\mathrm{Pa}$ leolithic art in the South, as with the classic chrono-cultural schemes of the Franco-Cantabrian regions, are based on the methods that are habitually used and accepted by the majority of Paleolithic rock art specialists. In the Andalusian case, this methodology is practiced by means of comparative morphological and thematic analyses with the imagery found on portable objects from well-excavated, dated archeological contexts, especially the large collection from Parpalló. At the same time, the inferences derived from multiple diachronic super-positions of rupestral images studied in La Pileta are valid, as are the several topo-iconographic compositions and techno-stylistic traits of several caves (Fortea, 1978; Villaverde, 1994, 2001; Sanchidrián, 1994a,b, 1997) and finally direct radiocarbon dating. In this regard, at present we have only three direct chronometric dates for Andalusian rock art, all done by AMS on charcoal pigment (Sanchidrián et al., 2001):

1. complete figure of an aurochs in the so-called Sanctuary Room of La Pileta: $20.130 \pm 350 \mathrm{BP}$;

2. meandering lines ("vermiculations") on a panel of the Lake Hall of La Pileta adjacent to two incomplete caprid figures: $8760 \pm 100 \mathrm{BP}$;

3. piece of charcoal within a few centimeters of the "black deer" in the Upper Galleries of Nerja: 19,900 \pm 210 BP.

The dates on both the aurochs of La Pileta and the deer of Nerja refer to the Middle Solutrean. There is perfect coherency between the dates and the cultural framework established by indirect means, such as the stratigraphic position of the bovine in La Pileta and the similar manner of "constructing" the plain anatomies of animals among the decorated slabs of the early levels in Parpalló in Valencia. Furthermore, in principle and based on their origins, the "vermiculations" in La Pileta were "washed" and consequently their age was contaminated or rejuvenated. Neverthe-less the date could indicate a very late manifestation of Paleolithic-type art, perhaps in parallel with the last artistic phase of the Upper Magdalenian in La Pileta or with the drawings in the Cave of Ojo Guareña (Burgos), although the drawings of incomplete caprids, from which the dated charcoal probably had been taken to draw the "vermiculations" are not too far out of line with the attributes of certain specific images from the final Magdalenian of Parpalló. In any event, we hope these problems can be solved during our next round of sampling for more AMS dating.

All in all, we conclude that there are three big chrono-cultural phases in the rock art that are in synchrony with the phases that have been established for the rest of Mediterranean Spain and for the Cantabrian region: 1) Gravettian-Early 
Solutrean; 2) Middle and Upper Solutrean; 3) Upper Magdalenian, perhaps with some hints of an Early Magdalenian and, at the other temporal extreme, survival up to ca. 10,000 BP-Epipaleolithic. Nevertheless, we have to make it clear that it was the second phase, between ca. 20-16.5 kya, that saw an explosion of artistic activity throughout the whole region, obviously in line with an increase in human population as manifested by the large number of rich Solutrean sites characterized by tanged and stemmed projectile points.

Currently, the only indices of older artistic activity in Andalucía and Extremadura are found in the caves of Doña Trinidad de Ardales, Maltravieso and La Pileta, perhaps as a result of low human population density with a subsistence regimen based on opportunistic foraging. In Ardales there are several black negative handprints, some with bent fingers (Cantalejo et al., 2003, 2006), a motif which is also very frequent in Maltravieso, where the 71 handprints are done in red (Ripoll et al., 1999). In La Pileta there is an ensemble of animal figures (red deer and aurochs) which are painted yellow and display very conventional anatomies that are similar to animals of the same early phase in the Asturian sector of the Cantabrian region (Sanchidrián, 2000b; Sanchidrián and Márquez, 2003).

As noted above, it was the Solutrean that witnessed the greatest amount of Paleolithic artistic activity in Andalucía. In general, the rupestral representations of animals show simple, highly stereotypical figures (Figs. 10 and 11), as is also the case among the Solutrean slabs in Parpalló (Villaverde, 1994, 2001). For example: the straight bi-angular perspective or arched legs in some forelimbs (at Pileta and Piedras Blancas); horses with a sinuous jaw line and flat muzzle (at Nerja, Pileta, Moro, Ardales) (Fig. 12); deer hind heads formed by archetypical triple lines (Nerja, Ardales, Pileta), as well as necks that are exaggeratedly long and elongated bodies (Nerja, Ardales) (Fig. 13); aurochsen with prominent foreheads, U-profile horns, quadrangular bodies and concave backs (Pileta, Navarro) (Fig. 12) very similar to the aurochs in the Solutrean cave site of Tête du Lion in the French Rhone Valley.

\section{Artistic Themes and Meanings}

The repertoire of themes represented in Solutrean-age art is very limited, the animals being only aurochsen, horses, ibex, red deer hinds and stags. However the signs are more abundant and diverse, although generally quite simple, consisting of straight lines and dots arranged in a large number of forms (lines of dots, rectilinear sheaves, paired lines, long parallel lines, angled lines, cruciforms, perpendicular lines, etc.) (Fig. 14), in addition to more complex signs such as circular and quadrangular ones (Fig. 15). Signs far outnumber animal figures and indeed there are some loci where they make up ca. $99 \%$ of the images (Nerja, Navarro, Victoria, Toro, Malalmuerzo, Almaceta, Pileta). At the same time these sites are also similar in terms of their overall topo-iconographic devices, in which small numbers or 


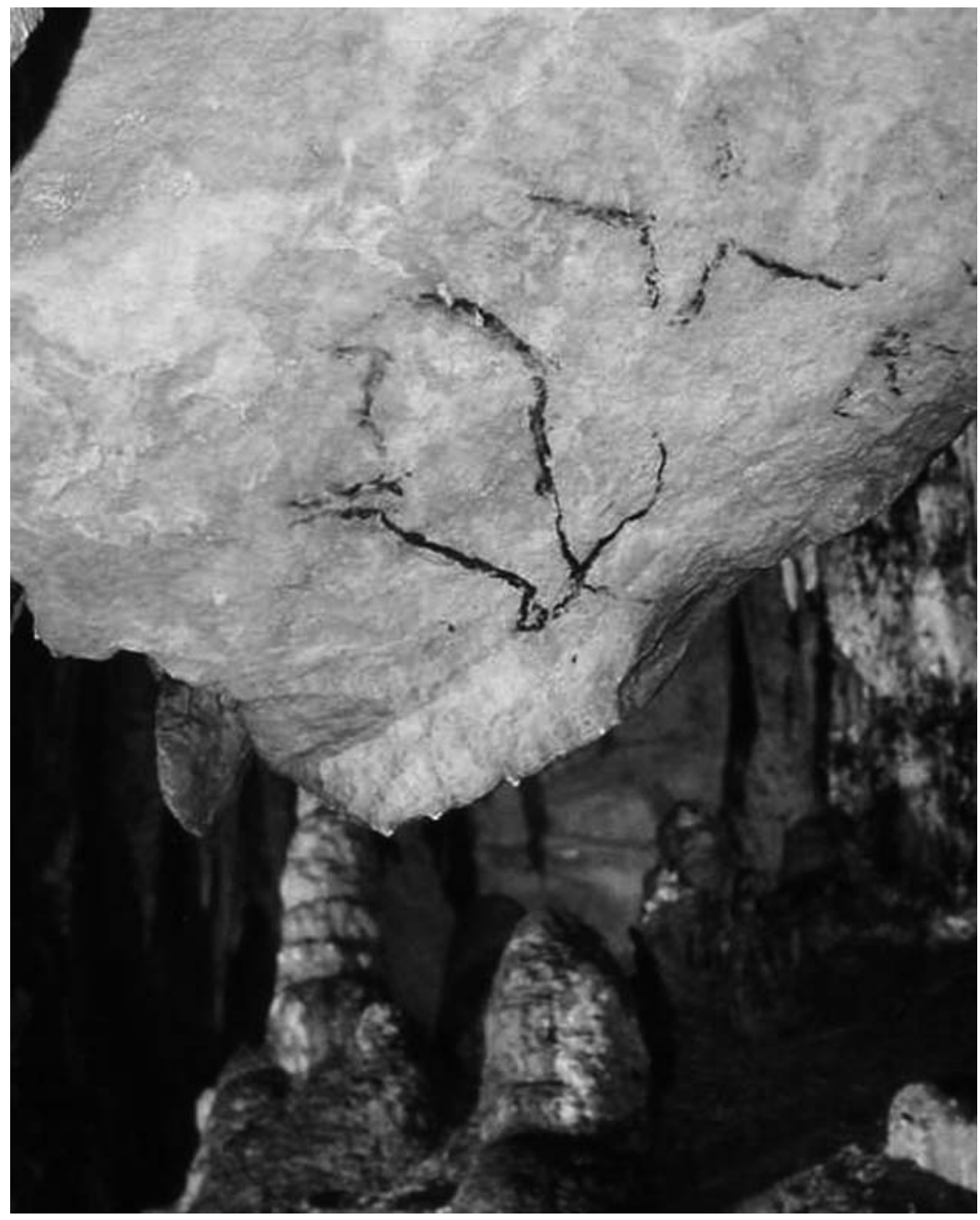

Fig. 10. Black ibex (and sign) on the ceiling of Nerja Cave (J. L. Sanchidrián).

individual animals (aurochs, deer) are surrounded by a mass of recurrent signs. Furthermore, in compositions with many signs, despite their, at first site, apparent chaotic aspect, one can begin to make out "coded graphic messages" which are organized according to regular combinations of elements which serve as the basis for a general syntax (Fig. 16). Nonetheless, at this time it seems that these symbolic rhythms of signs might have a regional significance, since we cannot surmise anything more of a convincing nature for the vast area of Andalucía. Likewise these signs seem to have been made during a fairly short time (during the late Solutrean, 


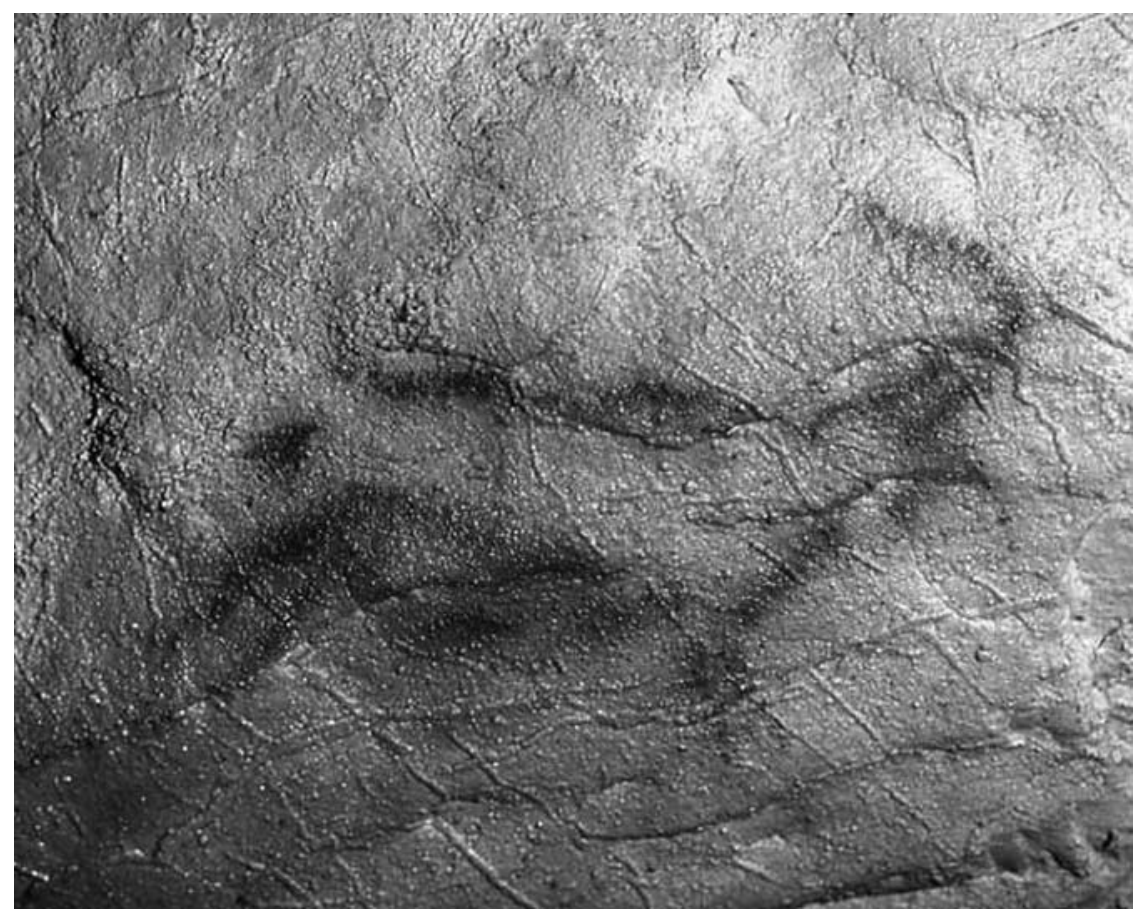

Fig. 11. Red ibex in Morrón Cave (J. L. Sanchidrián).

ca. 18-16.5 kya), a fact that would indicate a strong sense of territorialism among the human groups at this time of relatively high demographic density.

However, by virtue of what has just been stated, we are beginning to wonder if the beginnings of "writing" might have been much earlier than is usually believed (even if it may have disappeared only to be re-invented under different historic circumstances several millennia later). The graphic language or rupestral visual communication system of the Solutrean probably had a restricted character, quite different from the traditional function of writing among the earliest literate societies, separate from the fact that the primary motivation of a need to control the message by means of durable media was different from that which developed in the caves.

The restrictive matrix (or the context of use by a limited number of "chosen" people involved in rites de passage such as initiation) of the combinations of Paleolithic signs is not only supplied by their location in deep, dark underground settings, but also by the imbricated places which they occupy, where only a few people could have fitted in together. Thus, factors such as the unusual and hostile setting lead us to think that the phenomenon of such concentrations of signs were not used by large numbers of people. On the contrary, we can intuit 


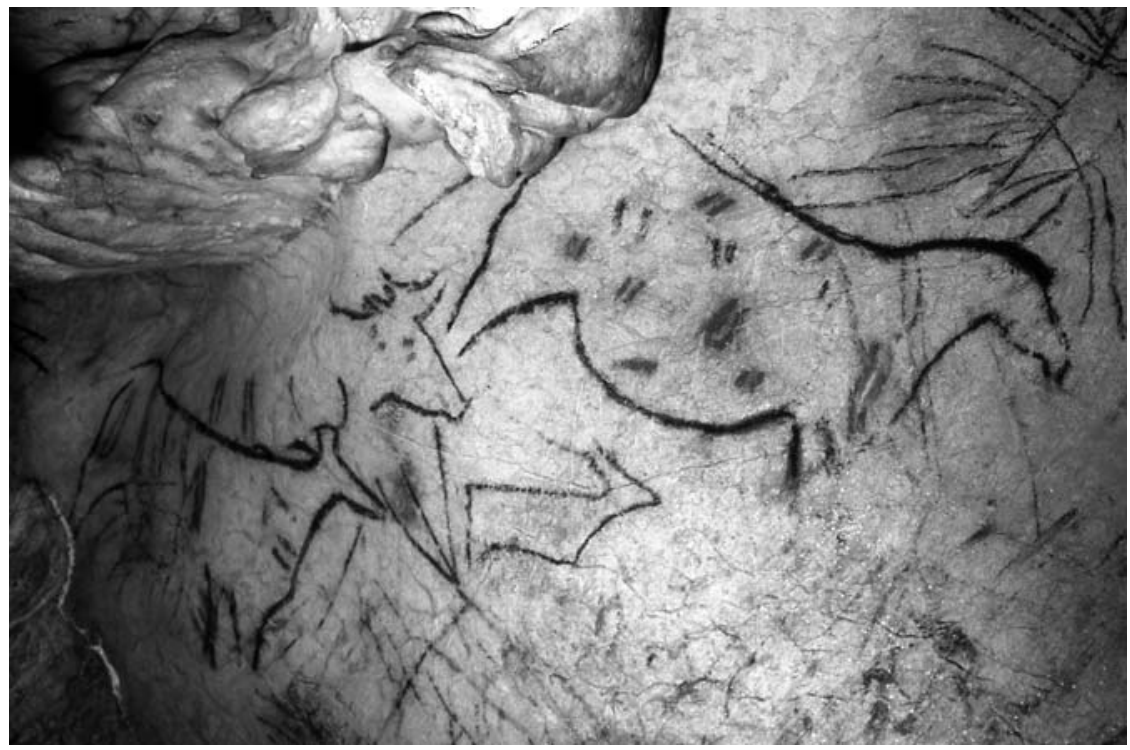

Fig. 12. Some of the drawings in the "Breuil Alcove" in La Pileta Cave (J. L. Sanchidrián).

that there may have existed certain distinctions among community members that were independent of the plausible socio-economic equality of the organization of Upper Paleolithic foragers. At any rate, the perception of the presence of graphic codes implies both knowledge and the learning thereof, and thus the existence of individuals with the role of "decoders".

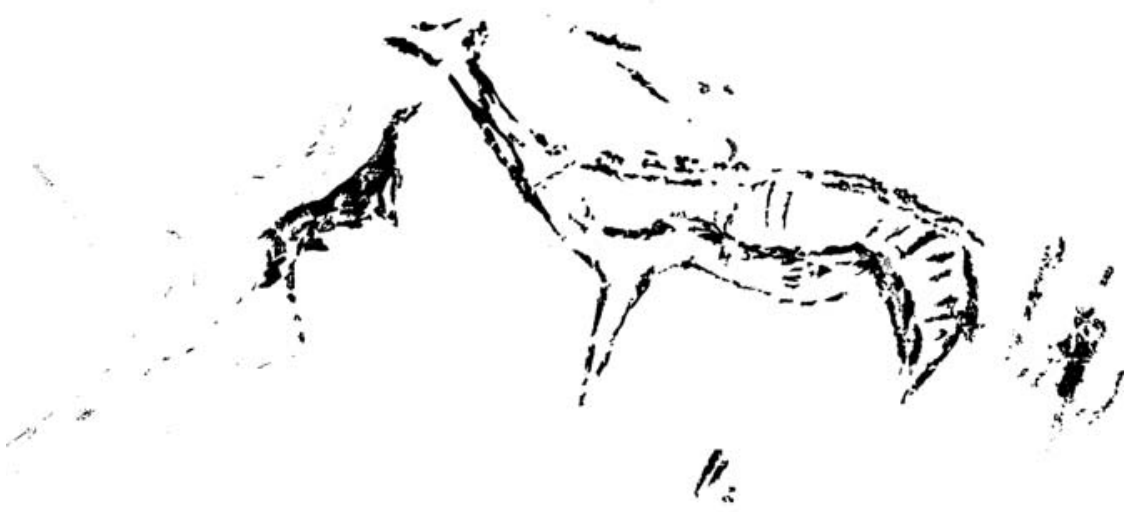

Fig. 13. Panel of the Great Black Hind in Doña Trinidad de Ardales Cave (J. L. Sanchidrián). 


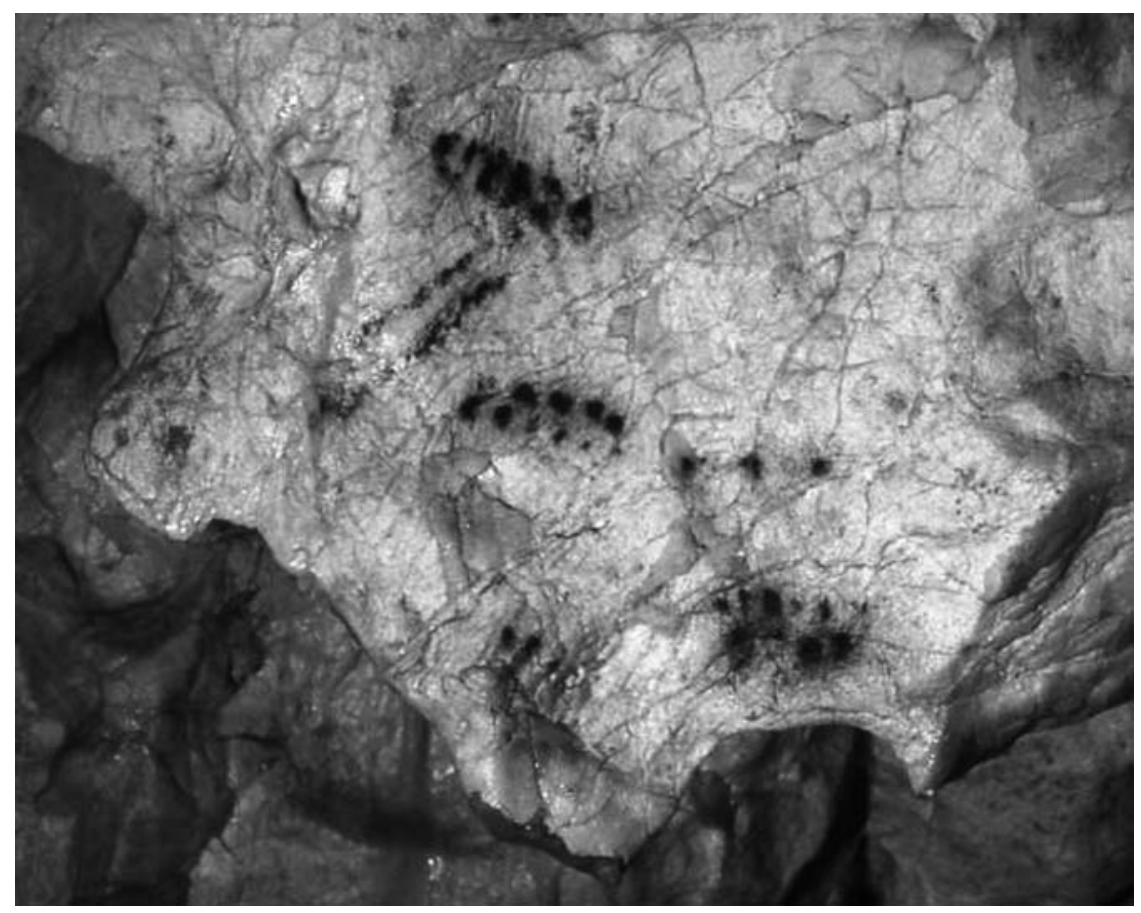

Fig. 14. Ensemble of black dots and lines in Navarro Cave (J. L. Sanchidrián).

The development of Magdalenian art brought with it some changes in themes and an increase in the naturalism of animal representations, meaning that the animal images are better finished and include complementary internal details which give a fuller sense of their bodies and greater realism (Fig. 17). Red deer hinds disappear from the iconography and marine animals (fish, seals) appear (Fig. 18), while aurochsen, ibex, stags and horses continue to be represented. The signs also change, with quadrangles and circles replaced basically by wavy lines. From the economic perspective, the Magdalenian foragers broadened the spectrum of food resources exploited, a phenomenon which led them to decrease their mobility and to use smaller territories than before. Perhaps this new situation is reflected by the disappearance of those sanctuaries with signs that had been so widespread throughout southern Spain during the Solutrean. The "minor sites" ceased to have meaning under changed conditions of demography, settlement and subsistence, and only the major sanctuaries in large caves remained (Pileta, Nerja and perhaps Ardales), since in all of Andalucía only these preserve clear figurative expressions created in the terminal Paleolithic period. 


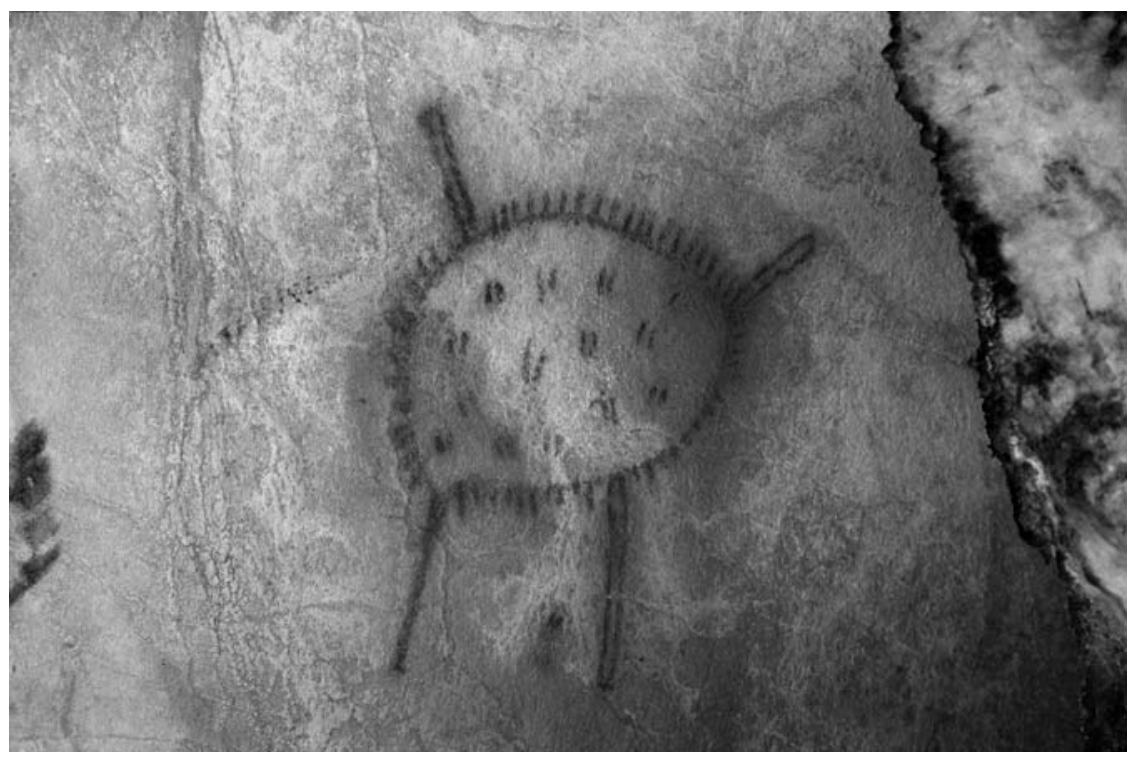

Fig. 15. Red circular sign in La Pileta Cave (J. L. Sanchidrián).

\section{PORTUGAL (AFC \& NB)}

\section{The Short History of Research and a Current Inventory of Rock Art Sites}

The discovery of the first Paleolithic art sites in Portugal was accidental. Because of this fact, those finds are in widely separated areas with no other evidence of contemporaneous human activity in their vicinities. The first site, Escoural Cave (Fig. 19a:7) was found in 1963 in a limestone quarry in central Alentejo (southern Portugal). Preliminary studies were conducted the same year by Farinha dos Santos (Santos, 1964; Glory et al., 1965). Santos returned a decade later and found a series of zoomorphic depictions, mostly equids and bovines (Fig. 20), as well as numerous abstract signs (Santos et al., 1981). These figures were classified into two phases: the older one, composed of painted and engraved zoomorphic themes was attributed to the Gravettian; the second, composed of geometric and abstract signs made by fine incision, probably during Magdalenian times. Small lithic assemblages have been found in the cave at different times, including material dated to the Mousterian by Otte and Silva (1996) and to the Solutrean (Zilhão, 1997a). Four Dufour bladelets have been published by Zilhão (1997a) as Aurignacian, although recently Bicho (2005a) proposed a more recent age - probably Gravettian. If correct, this would match the proposed chronology for the older phase of artistic 


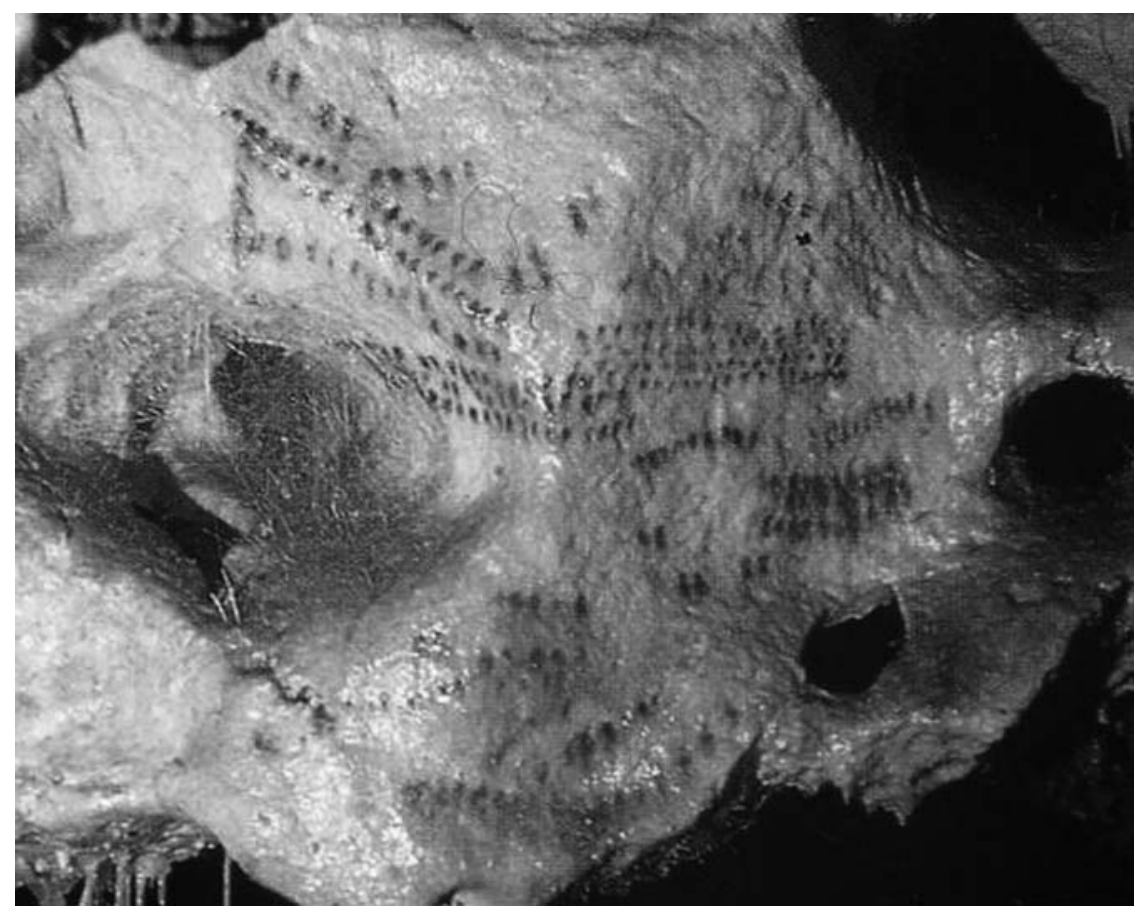

Fig. 16. Ensemble of combinations of rowed signs in Navarro Cave (J. L. Sanchidrián).

activity in Escoural. A generic "Upper Paleolithic" attribution of the art was based initially only on stylistic arguments, but the discovery of calcite films over some of the figures has helped to confirm the antiquity of the decorated panels. Escoural is still the only known Paleolithic cave art site in Portugal.

The second rock art discovery in Portugal took place at the beginning of the 1980s at the site of Mazouco, on the left margin of the Douro (Duero) River in the Northeast (Fig. 19a:3). There is a single panel, decorated with a clear engraved equid, along with two other less distinct figures, of which one is possibly also a horse. This panel is on an open-air schist outcrop surface. Mazouco was one of the first discoveries of open-air Paleolithic rock art in Europe (Jorge et al., 1981), along with the complex of Domingo García on the Spanish meseta and the site of Fornols Haut in the eastern French Pyrenees. Dating of the Mazouco horse is based on stylistic attributes which suggest a Middle or Upper Magdalenian age, according to the classic chronological scheme of André Leroi-Gourhan.

With the scientific discovery in 1994-1995 of the extensive Côa Valley rock art complex and its on-going study, Portugal entered a new phase of Paleolithic art research that became the springboard for new discoveries. These have resulted almost exclusively from archeological programs to evaluate the environmental 

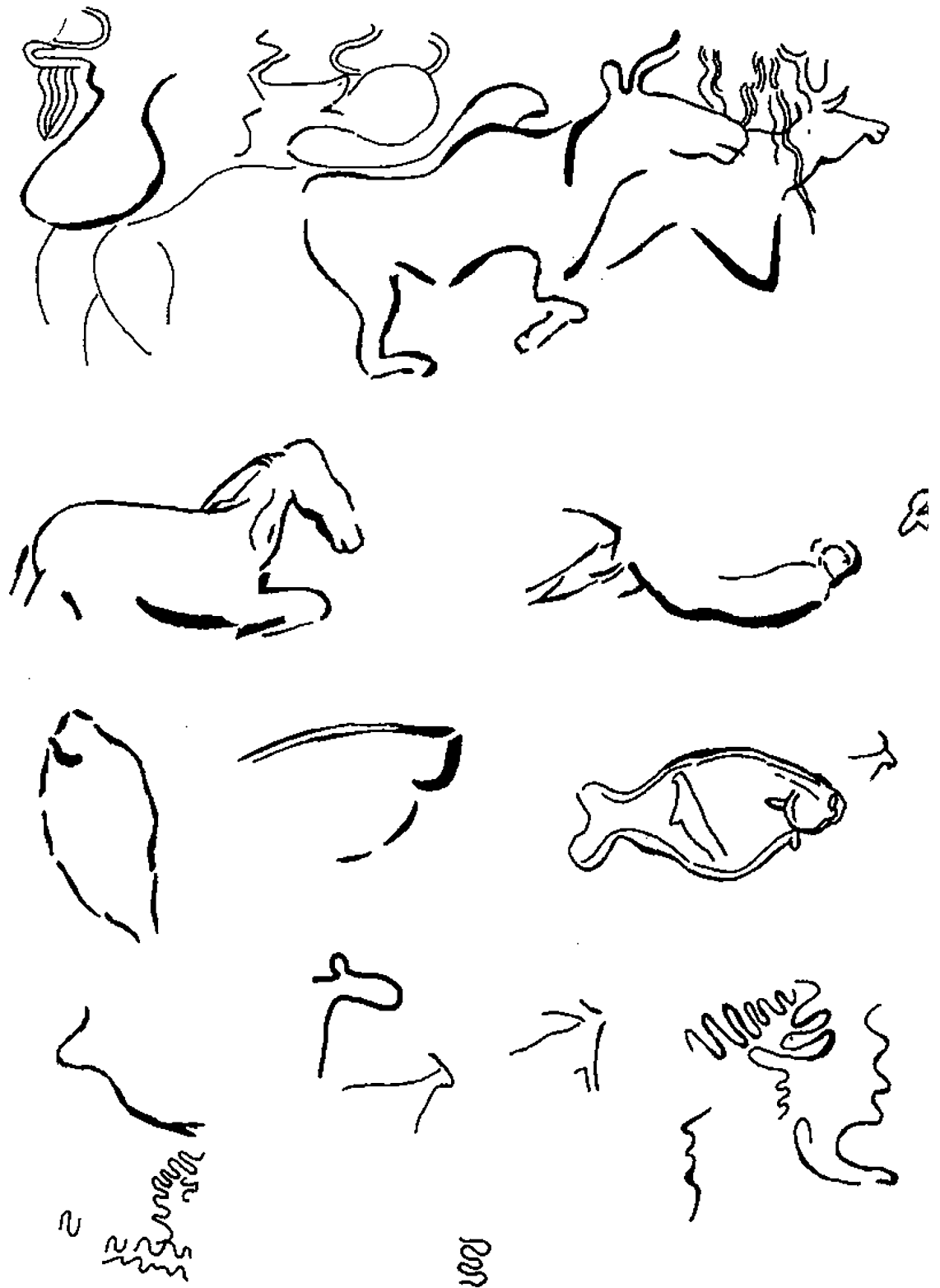

Fig. 17. Composite schematic of some Magdalenian motifs in La Pileta Cave (J. L. Sanchidrián). 


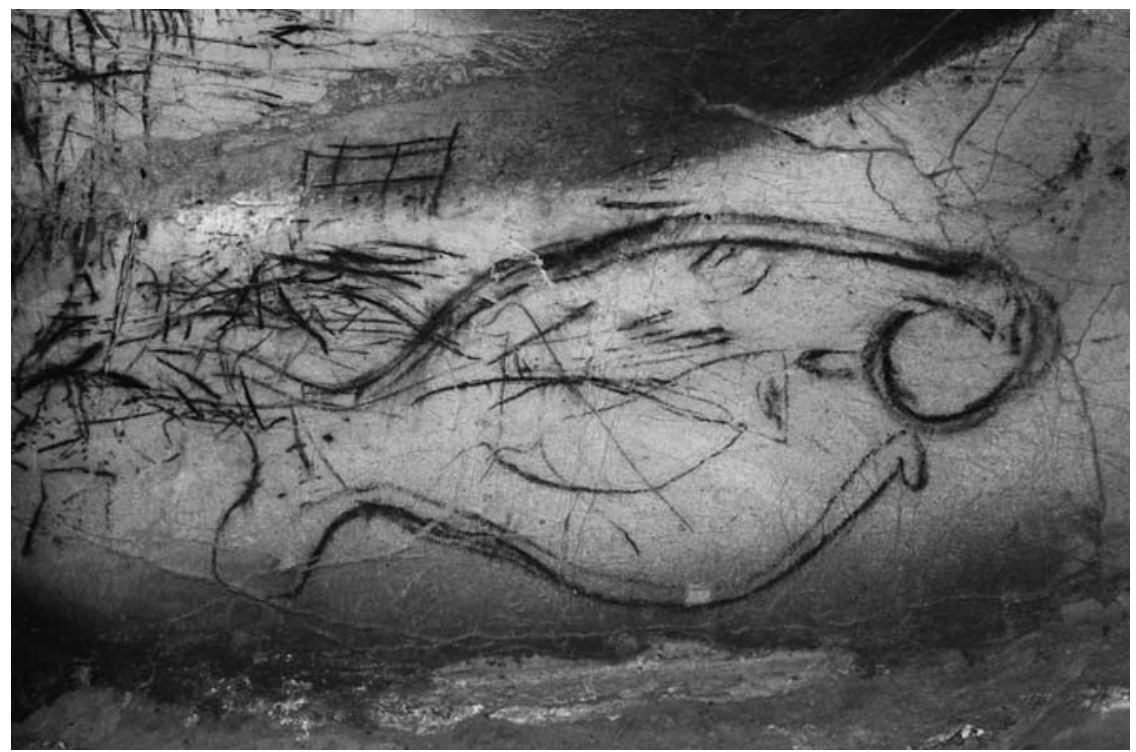

Fig. 18. Detail of the Great Black Fish in La Pileta Cave (J. L. Sanchidrián).

impacts of major public works projects, such as dams and highways, as Portugal rapidly modernized after joining the European Economic Community. In this context, the creation of the Instituto Português de Arqueologia (IPA) in 1996 was fundamental. Within that governmental institution was established an office dedicated specifically to research on rock art: Centro Nacional de Arte Rupestre (CNART). The IPA was a direct consequence of the discovery of rock art in the Côa Valley, as will be discussed below. Other open-air rock art sites outside the Côa Valley that have been found in the last decade are briefly characterized from North to South as follows:

Pousadouro, Sampaio, and Fraga Escrevida, Trás-os-Montes region (Fig. 19a:1). There only a single reference to these locations (Zilhão, 2001). These sites were found during a survey coordinated by the local IPA office in 2001. The art consists of a few decorated panels with zoomorphic elements made by pecking. Ribeira da Sardinha, Tras-os-Montes (Fig. 19a:2). At this site, located on a margin of the Sabor River, a tribuary of the Douro, there is a single depiction of an aurochs (Baptista, 2001a). This find, but may indicate the presence of other-as yet not found-occurences in this region. The site was found in the context of a dam survey.

Quinta da Moreirola, Beira Alta region (Fig. 19a:4). Still unpublished, this single panel was discovered in 2001 during survey for the high Côa dam, upstream of 

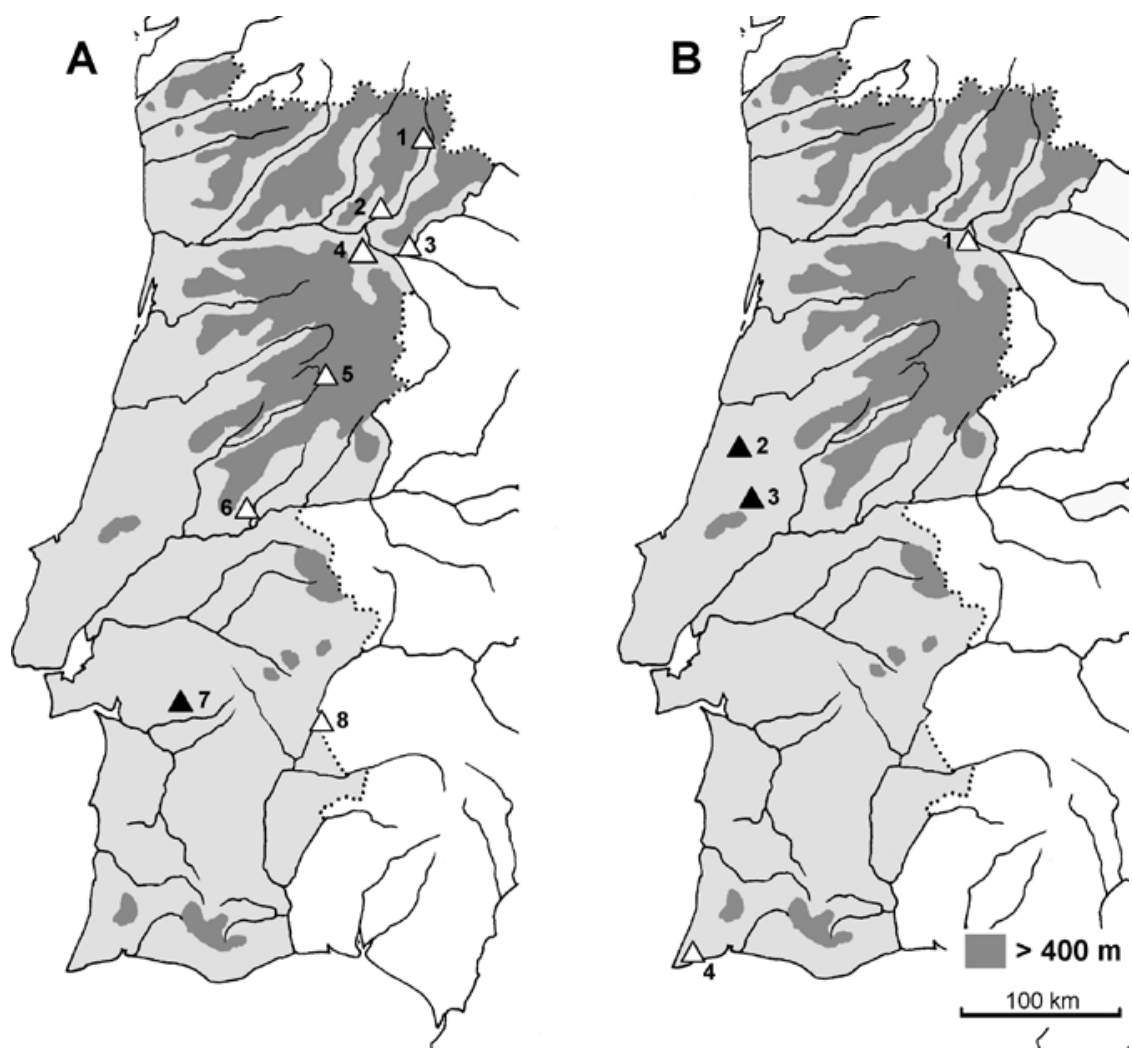

Fig. 19. Paleolithic Art of Portugal. Open triangles = open-air sites; solid triangles = cave sites (A.Carvalho and N.Bicho). (A) Rock Art: 1. Pousadouro, Sampaio and Fraga Escrevida (Bragança); 2. Ribeira da Sardinha (Torre de Moncorvo); 3. Mazouco (Freixo de Espada-à-Cinta); 4. Vale do Côa (Vila Nova de Foz Côa) and Quinta da Moreirola (Pinhel); 5. Poço do Caldeirão (Covilhã); 6. Ocreza (Mação); Escoural Cave (Montemor-o-Novo); Molino Manzanez (Badajoz, Spain). (B) Portable Art: 1. Fariseu and Quinta da Barca Sul (Vila Nova de Foz Côa); 2. Buraca Grande (Pombal); 3. Gruta do Caldeirão (Tomar); 4. Vale Boi (Vila do Bispo).

the main Côa site concentration. It is a figure of an ibex made by fine incision, probably of Magdalenian age.

Poço do Caldeirão, Beira Alta region (Fig. 19a:5). Two panels of figures made by the pecking technique were identified by chance on a rock on the right margin of the Zêzere River. One of the panels has two caprids and the other three equids. Both are thought to date, by stylistic comparison to the Côa art, to the Solutrean and Magdalenian (Baptista, 2004).

Ocreza, Beira Baixa region (Fig. 19a:6). This locus is found within the vast schematic rock art complex of the Tagus River Basin, generally dated between the Neolithic and Bronze Age). The stylistically very distinctive and 

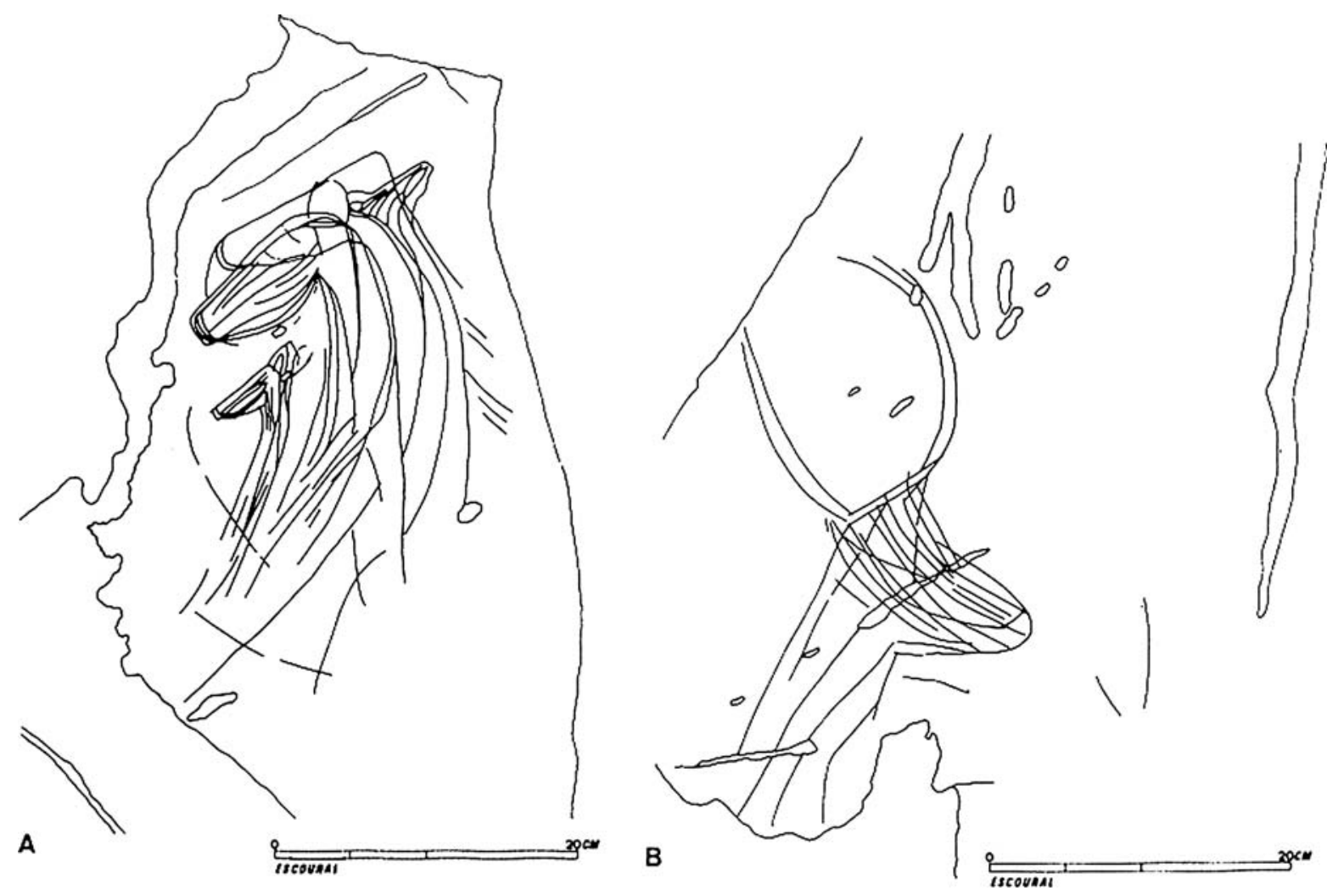

Fig. 20. Escoural Cave: zoomorphic depictions made by fine incision (after Santos et al., 1981, Fig. 9). (A) Two horse heads. (B) Aurochs head. 
thus Paleolithic panel has a single engraved horse found during survey for an environmental impact study (Baptista, 2001).

Molino Manzanez, Spanish Extremadura (Fig. 19a:8). Although located on the left (i.e., Spanish) bank of the Guadiana River, this group of Paleolithic engraved images was found during survey for the huge Alqueva dam located in Portuguese territory. This locus has a cluster of signs of various types together with zoomorphic representations (bovines, equids and especially cervids) made by fine incision (Collado, 2002). The Paleolithic examples are surrounded by a more extensive, Holocene-age, schematic rock art complex that extends across both sides of the Guadiana on the plains of Portuguese Alentejo.

Mobile art (Fig. 19b) has a different geographic distribution pattern and has been found during several systematic archeological excavations since the 1980s, both in caves - Caldeirão (Zilhão, 1988) and Buraca Grande (Aubry and Moura, 1994) — and in the open air - Quinta da Barca Sul and Fariseu (Garcia and Aubry, 2002) and Vale Boi (Bicho, 2005b). In the majority of these sites there are only single artifacts (engraved cobbles or slabs) on which either zoomorphic figures or abstract signs are represented. In Fariseu, with the Côa rock art complex, some 60 large schist cobbles and slabs were found during the 2005 excavation, following the discovery of two such cobbles during the 1999 excavation. Among this total, there are examples from both the early Gravettian and Magdalenian occupation layers (T. Aubry, personal communication, 2005). It is the most important and expressive assemblage of portable art from Portugal. Publication is pending.

\section{The Côa Valley}

Even though there are now considerable numbers of sites across the whole of Portugal, there is no doubt that currently, at least, the open-air rock art complex of the Côa Valley constitutes the most important assemblage of rock art in the country. This fact is due not only to its inherent value as a World Heritage Site, but also because of the scientific implications of its discovery and study. This is patent in some of the reevaluations of European Paleolithic art published immediately after the discovery of the Côa art (e.g., Bahn, 1995; Lorblanchet, 1995; Clottes and Lewis-Williams, 1996; Clottes, 1998).

The Côa River runs South to North, parallel to the Spanish-Portuguese border (Fig. 19a:4), reaching the Douro near the town of Vila Nova de Foz Côa. In the lower course of the river, where the rock art complex is located, the valley is narrow and deeply incised, especially in its upper stretch where it crosses granite formations. Between this point and the confluence with the Douro, the Côa flows through schists where fluvial beaches are present and in certain spots there are natural fords. In modern bioclimatic terms, the Lower Côa is a regiondespite its relatively high latitude-with marked Mediterranean characteristics: 
low rainfall levels and a very wide annual temperature range. The river water levels are torrential during the very cold winters, while in the summer the water table completely evaporates, leaving a dry river bed in the driest years. This scenario was certainly different during the Late Pleistocene, since the Serra da Estrela glaciers, located some 80-100 to the SSW, would have fed the Côa Basin most of the year.

The rock art of Côa was probably actually found at the end of 1992, during construction work on a coffer dam at the northern end of the river. Though its discovery and disclosure to the public were marked by a series of unusual events, there was a hot debate in 1994-1995 at the levels of both social interest and public policy in Portugal, especially concerning the decision to finish or to stop dam construction, as well as within the national and international scientific communities. The determination of the age of the Côa rock art was very controversial and the debate similar in some respects to the polemic, some 100 years earlier, about the authenticity and age of the Altamira cave art. In both cases, nonetheless, it was ultimately possible to prove the Pleistocene age of associated archeological materials, resulting - in the Côa case-in the decision of the newly (October, 1995) elected Socialist government to stop the construction of the large hydroelectric dam and to create the Parque Arqueológico do Vale do Côa (PAVC). That decision was based on a major scientific report published in full a year later (Zilhão, 1997b). This report was also the basis for the classification of the Côa Valley rock art complex as a UNESCO World Heritage Monument on December 2, 1998.

The results of the research carried out for the report were published in greater detail by Zilhão et al. (1997, 1998-99). In these papers, as well as in others published later, data and interpretations have been published on aspects of the geography, geomorphology and general characterization of the rock art, specifically on the distribution, techniques and motifs of the figures, chronology, interpretation and archeological contexts of the art. (The study of the Holocene artistic manifestations in the Côa Valley, dating mainly to the Chalcolithic, early Bronze Age and Iron Age (Carvalho and Baptista, 2002), is still in its preliminary stage.) According to the latest data (Baptista, n.d.), Paleolithic art extends over ca. $17 \mathrm{~km}$ of the valley, clustered in 26 individual locations, on 234 rocks, and including 744 distinct rock art centers, such as-from South to North-Faia, Penacosa, Quinta da Barca, Foz de Piscos, Ribeira de Piscos, Fariseu, and Canada do Inferno (Fig. 21).

\section{Dating and Principal Chronological Phases of the Côa Art}

During the "Côa debate," EDP (the Portuguese national electric company that was building the dam) funded experimental dating of some of the engravings. The initial objective was to show that the petroglyphs were of recent age and, thus, to decrease their importance, so that the dam could be built. In this effort, various 


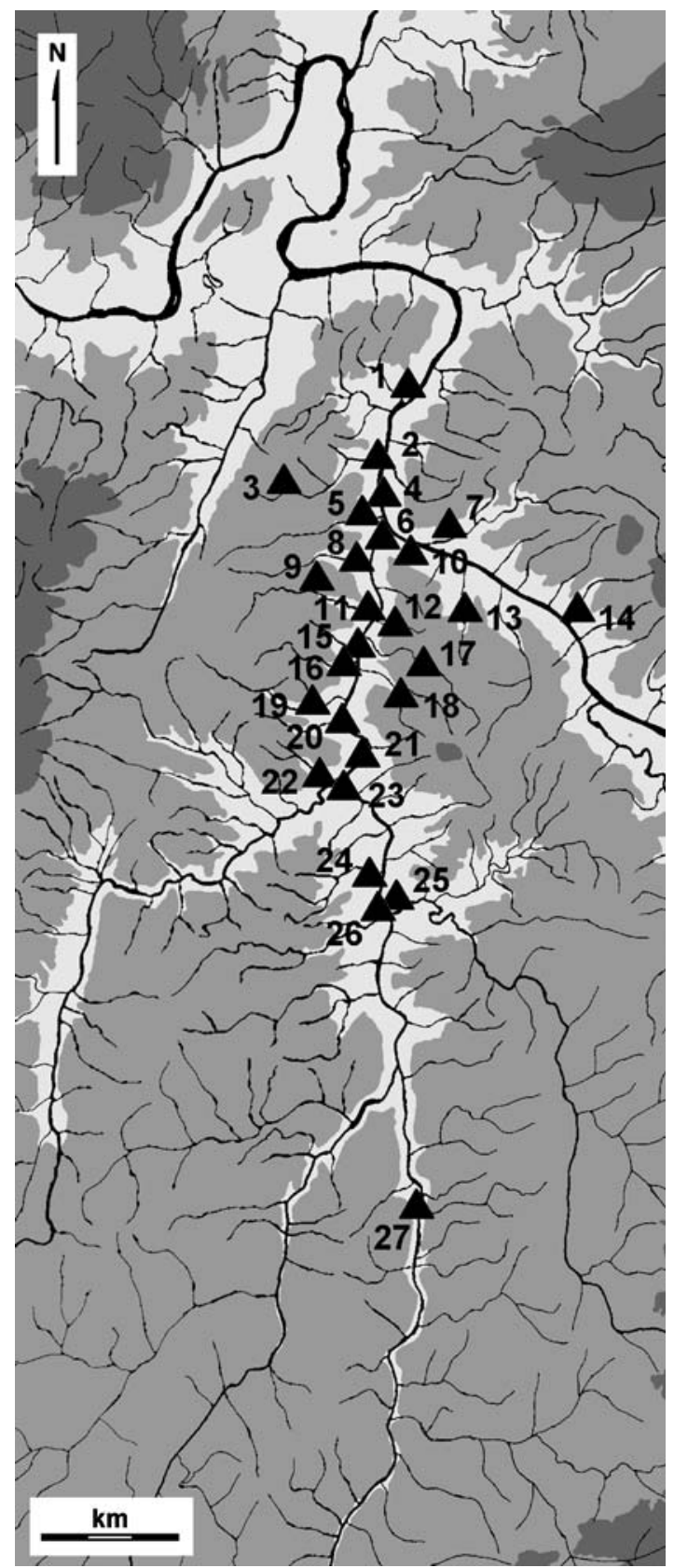

Fig. 21. 
methods were applied to the Côa engravings: micro-erosion dating (Bednarik, 1995), AMS dating of organic matter encapsulated in the minerals (Watchman, 1996) and in weathering rings (Dorn, 1997), and ${ }^{36} \mathrm{Cl}$ dating of the engraved surfaces themselves (Phillips et al., 1997). All the results of these different methods were shown to be inadequate and erroneous (Zilhão, 1995). The best of them were only able to given a terminus post quem or maximum date of 130,000 years in the case of the ${ }^{36} \mathrm{Cl}$ method (Dorn, 1997). Bednarik is still arguing for a postPaleolithic age for all the Côa engravings, affirming - despite all of the evidence to the contrary - that they are the work of modern people (!).

The survey of rock art loci, as well as archeological surveys and excavations carried out since 1995 have enabled the construction of a coherent chronological framework for the whole Côa complex (Zilhão, 1997b; Zilhão et al., 1997, 1998, 1999). One of the best examples that stratigraphically demonstrates the long span of human use of this valley is the case of a patinated cervid of Paleolithic style overlain by an unpatinated engraving of a horseman with typical Iron Age weapons at Vermelhosa (Fig. 22). There is also unequivocal dating evidence based on stylistic comparison with other European rock art sites. In fact, the open-air rock art of Côa, marked by a strongly naturalistic style, duplicates the themes (Fig. 23) and types of all western European Paleolithic art in such aspects as the high degree of zoomorphism and specific artistic conventions (e.g., dimension of figures, lateral perspectives of the bodies, heads and antlers/horns, sinuous cervico-dorsal lines of the bodies, distended bellies, lack of land surface indication, etc.).

The excavation of the Fariseu site in 1999 and 2005 has independently confirmed the Paleolithic age of the engravings. Before the excavation, a group of panels had been found on outcrops along the left margin of the river at the Fariseu location (Fig. 23). The excavation of the sediments accumulated up against those panels revealed a long stratigraphic sequence of alluvial and colluvial deposits containing in situ Upper Paleolithic levels with Pleistocene faunal remains. Based on typological and technological characteristics, the lithic assemblages are attributed to the late Magdalenian and late Gravettian (Aubry, 2002). Furthermore, the large assemblage of engraved slabs recently found in the archeological deposits

Fig. 21. Paleolithic open-air rock art sites of the Côa Valley: 1. Vale da Casa; 2. Vale de Cabrões; 3. Alto da Bulha; 4. Vermelhosa; 5. Vale de José Esteves; 6. Foz de Côa; 7. Ribeira de Urros; 8. Vale do Forno; 9. Moinho de Cima; 10. Quinta das Tulhas; 11. Vale de Moinhos; 12. Broeira; 13. Canada da Moreira; 14. Vale de João Esquerdo; 15. Rego da Vide; 16. Canada do Inferno; 17. Meijapão; 18. Canada do Amendoal; 19. Vale de Videiro; 20. Vale de Figueira; 21. Fariseu; 22. Ribeira de Piscos; 23. Foz de Piscos; 24. Ribeira de Cortes; 25. Penascosa; 26. Quinta da Barca; 27. Faia (A. F. Carvalho and N. Bicho). 


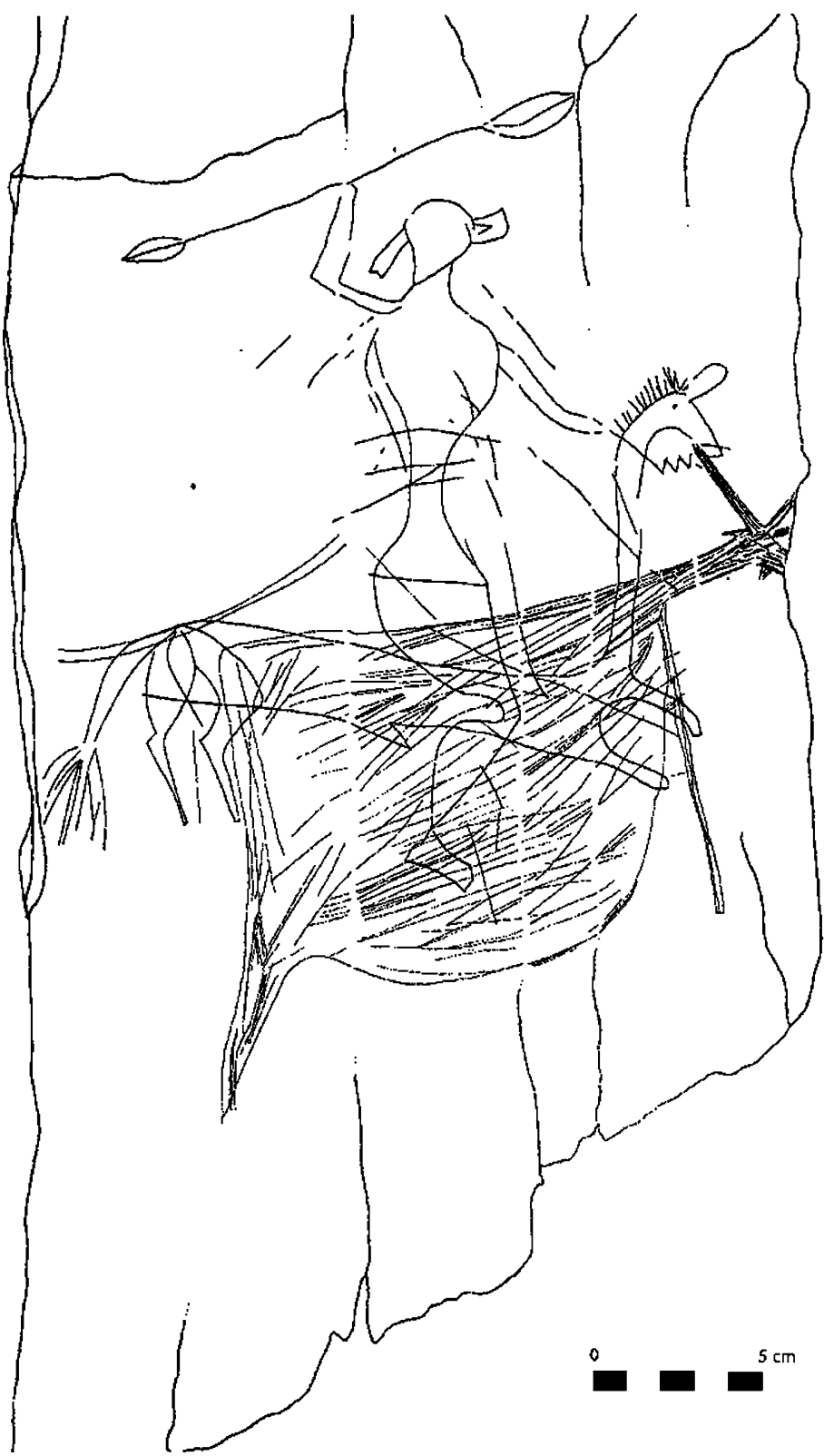

Fig. 22. Iron Age warrior image superimposed above a cervid figure of Paleolithic typology at the Côa Valley site of Vermelhosa (after Zilhão, 1997a, p. 33). 


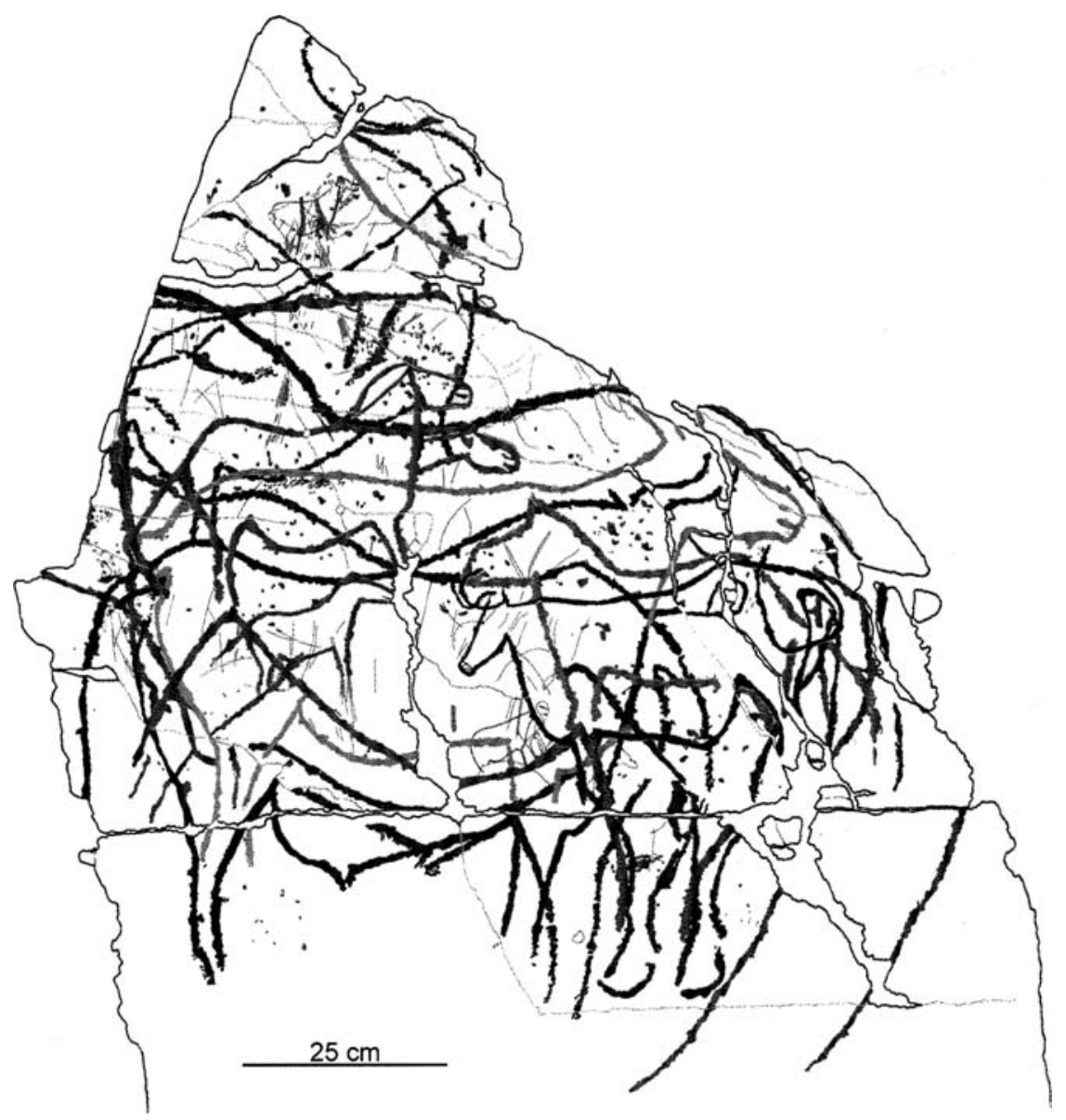

Fig. 23. Right sector of Fariseu rock no. 1 (after Baptista, 2001b: Fig. 9).

will help in chrono-stylistic comparisons with the regional rupestral art, as has already been done with the first two portable art objects found during the 1999 excavation at Fariseu (Garcia and Aubry, 2002). In addition to showing that Upper Paleolithic occupation layers cover some of the lower engravings on the rock outcrops here, Fariseu displays clear homogeneity among the petroglyphs. The images encompass the whole range of characteristics found in the Côa pecked style, with such motifs as animals with multiple superimposed heads. These facts permit us not only to confirm a Pleistocene age for most of the Côa art, but also to give a terminus post quem of Gravettian age to that specific style and technique of the art at Fariseu. Since these are also present at other loci in the valley, they constitute the earliest phase of rock art, usually located near low fluvial beaches. 
The idea of an early artistic phase, probably of Gravettian age, suggests to Baptista (n.d.) the presence of an "archaic sanctuary" in the Côa Valley.

The second phase of the Côa Paleolithic art (the so-called "recent sanctuary") is represented by engravings made by fine incision. Their relative chronological position is provided by their overlying stratigraphic position relative to earlier petroglyphs and their almost complete absence in Fariseu. The distribution of the elements dating to this later phase-probably of Magdalenian age-seems to be less patterned than those from the Gravettian phase and they appear to be more frequently located along the tributaries of the Côa and in the area surrounding its confluence with the Douro.

\section{Techniques, Motifs and Stylistic Particularities}

The Côa rock art was made generally on schist and, more rarely, on granite outcrops in the form of benches along both sides of the river. Images were made by direct and indirect pecking, single or multiple line incision, abrasion and scraping. In one case, at Faia rockshelter, there is a composite panel with both engraving and painting. According to the most recent syntheses (Baptista, 2001b, n.d.), the motifs present in the Côa complex are mostly zoomorphic. In fact, abstract signs (such as zigzags, tectiforms, comets and lines plus dots) and anthropomorphic figures (present in Ribeira de Piscos and Foz de Piscos) are rare. The faunal species present are herbivores typical of the ecosystems of the Spanish meseta during the Upper Paleolithic: horse, aurochs, ibex and red deer. Representations of fish are rare and cold-adapted faunas are absent, with the possible exception of three examples of chamois at Fariseu. The relative frequencies of each species indicate the even representation of the first three (horse, aurochs and ibex)—with close to $18 \%$ each (Fig. 24). The cervids are mostly present in the second phase and may be indicators of environmental changes that occurred toward the end of the Last Glacial in the region.

The surveys and excavations carried out by the PAVC have identified various hunter-gatherer occupations in the Côa Valley, dating from the early Gravettian to the late Magdalenian (Aubry, 2002), which, starting in 1995, provided an archeological context to the rock art and supported its Pleistocene age. Recent work (Aubry et al., 2002, 2003; Aubry, 2005) on lithic raw material provenience, based on petrographic and paleontological characteristics of the flints in use during the Paleolithic, indicates that these silicious materials (which are locally completely absent) came from Portuguese Estremadura to the SW and the Spanish Central Meseta to the East, encompassing an area of ca. $50,000 \mathrm{~km}^{2}$. Aubry has postulated two models for the Côa area:

1. the Côa Valley was used sporadically by hunter-gatherer groups coming from both the Central Meseta and Portuguese Estremadura, or 


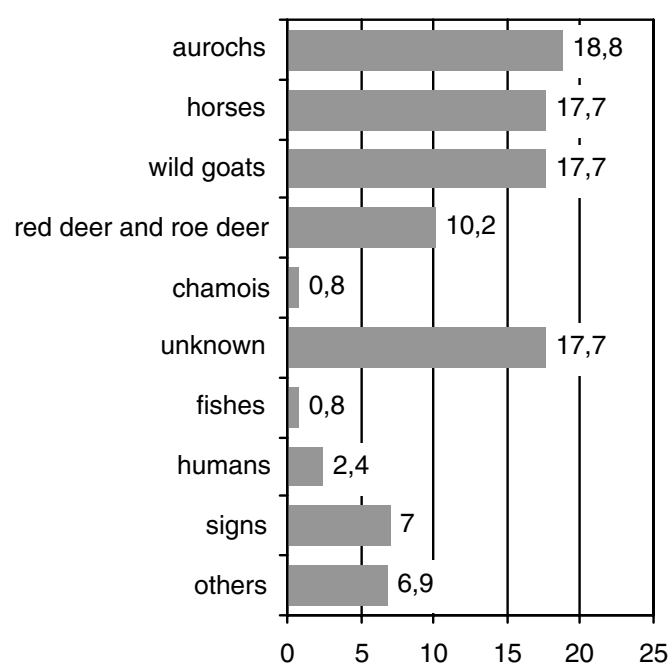

Fig. 24. Relative proportions of the themes depicted in the rock art of the Côa Valley (Baptista n.d.).

2. there was a resident community in the Côa area whose members would gather together with "foreign" groups, probably seasonally, at aggregation sites, thereby obtaining the exogenous flints.

The use of a particular type of dark rock crystal, naturally occurring in an area of 500-2000 km² which includes the Côa Valley and found at every archeological site in the valley, seems to support the second model. If this model is correct, then the Côa Valley may have been used as a large meeting area where social interactions and mate exchanges took place. Sites such as Fariseu would have been key locations, as suggested by the association of abundant portable and parietal art, as well as occupation horizons.

\section{Current State of Research and Politics of Management}

At present, it is possible to conclude that the Pleistocene rock art in Portugal is distributed more frequently in tributaries (Côa, Ocreza, Sabor, Zêzere) than in the valleys of the principal rivers that run to the Atlantic (Douro, Tagus, Guadiana) (Fig. 19a). Site locations are almost always in riverine environments, marked by the presence of schist and granite bedrock which, because of their hardness, likely contributed to the preservation of the Paleolithic art. Possibly, for the opposite geological reason, there are no open-air Pleistocene artistic manifestations in the limestone bedrock areas of Portuguese Estremadura or Algarve, although there exists the possibility that art might yet be found in the many caves of these regions. 
It should be noted that although Upper Paleolithic research has been conducted (albeit irregularly) since at least the end of the 19th century in Portugal, there have been no specific rock art surveys in either area. Thus, only the implementation of such research projects in areas that are geologically suitable for the preservation of rock art (such as limestone caves, as well as the schist areas of the Algarve and coastal Alentejo) may either confirm its absence or, to the contrary (by finding art), indicate that the presently apparent geographical hiatus is only the result of the current lack of specific rock survey in southern Portugal.

The Portuguese Ministry of Culture - through the IPA — has enabled the environmental impact studies of major construction projects that, in turn, have resulted in the discovery of most of the Paleolithic rock art sites in the country. The management, protection and preservation of rock art sites, as well as promotion of public access to the Côa Valley and Escoural Cave, are also the responsibility of the Ministry of Culture. In the case of Escoural, the cave is controlled by the Instituto Português do Património Arquitectónico, while the Côa sites are controlled by the PAVC, the only archeological park in Portugal, with visitor centers near the sites of Penascosa, Ribeira de Piscos and Canada do Inferno. The PAVC management guidelines have been published internationally (Zilhão et al., 1999). A local museum is presently projected by the IPA to be open to the public in 2008 .

\section{THE TERRITORIES OF THE IBERIAN INTERIOR (CGS)}

The interior of the Iberian Peninsula now has a number of cave and openair rock art localities, some quite large. Although stylistic analyses assure their Paleolithic age, their interpretation is hindered by a scarcity of preserved living sites. There are really only a very few sites with finds of lithic artifacts or works of portable art of Upper Paleolithic aspect, but there are no published industrial or faunal series with precise stratigraphic or chronological contexts. Recent studies have been attempting to remedy this situation. One such study is the current excavation of Paleolithic deposits at the mouth of the decorated cave of $\mathrm{La} \mathrm{Hoz}$ in Guadalajara, where surface finds had included stone slabs with representational engravings (Balbín et al., 1995, 1997, p. 107) and in the rockshelter of Peña de Estebanvela, where notable portable art objects have been found in Tardiglacial levels (Ripoll and Muñoz, 2003).

The Universities of Salamanca, Alcalá de Henares, and National Distance Learning (UNED-Madrid) concentrate much of their Paleolithic research on the rock art of the northern tablelands (mesetas). These projects are trying to provide consistency to our knowledge of the art of these high, harsh interior regions by defining its specific regional characteristics, recurring techniques, forms and compositions (e.g., Balbín and Alcolea, 1995, 1997; Alcolea and Balbín, 2003). On the other hand, in order to establish a chronological framework it is essential to 
compare the art of the mesetas with that of the artistically richer but geographically peripheral regions of the Peninula (notably Vasco-Cantabria, the collections of decorated slabs from Parpalló, and the open-air sites of Côa). The result of such comparisons can lead to divergent interpretations between the rock art record and the archeological record of living sites, particularly as concerns the question of the extent of human occupation of the interior during the Last Glacial Maximum. As a result, the chronological attribution of the rock art manifestations of the mesetas is quite diverse, ranging from a short, late chronology (i.e., essentially Magdalenian (e.g., Corchón, 1997, 2002)) or a longer, more continuous record of artistic activity beginning in the Gravettian (Balbín and Alcolea, 1995, 1997; Alcolea and Balbín, 2003). The latter view takes into account the (at least limited) presence of both cold fauna and of Solutrean lithic assemblages on the mesetas.

\section{Geographic Distribution and Chronological Arguments}

Leaving aside the rock art sites of Aragón, La Mancha and Spanish Extremadura mentioned elsewhere in this article, this section discusses phenomena located in three northern and central zones of the Spanish interior, with sites located at elevations between $500 \mathrm{~m}$ above present sea level (Siega Verde in the West) and somewhat over $1000 \mathrm{~m}$ (the eastern sites).

\section{The Upper Ebro Basin in Old Castile}

The high tablelands northern Burgos in the northeastern part of the Autonomous Region of Castile and León have only two rock art sites: Penches Cave with a small group of engravings (essentially five ibex figures and other less clearly interpretable marks) of Paleolithic style and probable Magdalenian age (Balbín and Alcolea, 1997). The second locus is Palomera Cave, which is part of the vast Ojo Guareña karstic complex, with a small number of charcoal drawings of animals and anthropomorphs. These have yielded a series of five radiocarbon dates that indicate an age toward the end of the Late Glacial Interstadial, between ca. 11.5-11 kya (Corchón et al., 1996; Corchón, 2002, p. 88). Both the dates and the style of the figures (only remotely "Paleolithic") tend to distance them from representations in the nearby Cantabrian region and suggest the existence of different graphic traditions. Beyond a few elements corresponding to a Magdalenian age $\left(a^{14} \mathrm{C}\right.$ date on surface materials from La Galeria de las Huellas in Ojo Guareña, some artifacts in Caballón Cave), the presence of human occupations in this region only become clear at the time of the Late Glacial Interstadial (i.e., terminal Magdalenian/Azilian) (Corchón, 2002), but especially in later times (Alday, 2002). With respect to the possibility of older episodes of occupation, it is important to note two facts: the existence of early Upper Paleolithic sites in the Upper Ebro 
Basin (Utrilla, 1987, 1995) and the evidence from lithic raw material analyses of human movements between this area and the eastern sector of the Cantabrian region (Tarriño, 2002).

\section{The Spanish Duero River Basin}

Upstream of Côa and in the southern half of the Duero Basin there are a few interesting rock art loci: the Cave of La Griega and the open-air complexes of Siega Verde and Domingo Garcia. The engravings of La Griega are the subject of an extensive monograph by Corchón (1997). They include images of about 90 animals and anthropomorphs and 29 signs attributed to the Upper Paleolithic, as well as other figures of post-Paleolithic age. As in many of the other rock art loci on the northern mesetas, almost all the represented animals are horses, although aurochs, red deer are also shown, and there are other more problematic images. Based on some superpositions and other criteria, as many as four Pleistocene phases of decoration have been detected in La Griega, all, however, attributable to the Magdalenian according to Corchón (1997, p. 156 et passim). This hypothesis is in sharp contradiction with other assessments - also stylistic in nature-that suggest an older chronology for this cave in Segovia.

The open-air loci of Old Castile are clearly similar to the Portuguese ones, with Siega Verde being close to Côa. They are all characterized by the use of pecking, and - for the smallest figures-fine incision. There are also similarities in terms of formal characteristics. The Siega Verde complex extends over $1.5 \mathrm{~km}$ of schist outcrops along the Agueda River in the area of a ford. So far, more than 530 figures have been found, including over 250 animals (mainly horses, aurochsen and cervids, plus a few ibex, carnivores and indeterminate quadripeds). Stylistically, these figures have been attributed to Leroi-Gourhan's Styles III and early IV, which are supposed to correspond to the Upper Solutrean and Lower Magdalenian (Alcolea, 1996; Balbín et al., 1996).

Domingo Garcia is unlike the other open-air loci of Spain and Portugal in not being associated with a river. Following an initial study by Martín and Moure (1981), a recent monograph (Ripoll and Municio, 1999) identifies up to eight separate slate outcrops with engravings of Paleolithic style in an area of about $20 \mathrm{~km}^{2}$ at elevations somewhat above $900 \mathrm{~m}$. The clusters at El Cerro de San Isidro, Canteras and Dehesa de Carboneros contain most of the known engravings. Up to 115 figures of horses, red deer stags and hinds, caprids, aurochsen and indeterminate animals have been documented. The techniques used (pecking, fine incision, and sometimes even internal "shading") are similar to those used at other open-air complexes in the Duero Basin. Based on stylistic criteria, the art of Domingo Garcia has been attributed to the Solutrean and Magdalenian.

These rock art sites are complemented by portable art objects from a pair of sites in the Upper Duero Basin: an isolated stone retoucher with engravings of 
ibex and horses found on the surface at Villalba, Soria (Jimeno et al., 1990) and, especially, a series of decorated cobbles and slabs found in the fairly thick deposit of Upper Magdalenian and initial Epipaleolithic levels in La Peña de Estebanvela rockshelter in Guadalajara (Ripoll and Muñoz, 2003).

\section{Rock Art Localities of the Upper Tagus Basin}

In the headwaters area of tributaries of the Tagus River, on southern slopes of the Central Mountain Chain and on the southwestern edges of the Iberian Chain in Castile_-all in Guadalajara Province - the research group from the University of Alcalá has been defining a notable group of caves with Paleolithic art, by means of new studies of the long-known sites of Los Casares, La Hoz and El Reguerillo. The first two (which are better preserved) have yielded significant new art finds. This research group also has also studied more recently discovered art caves: El Turismo (Alcolea et al., 1995) and El Reno (Alcolea et al., 1997, 2000). In addition, they have undertaken the comparative analysis of these sites and other loci in the interior of the Peninsula (Alcolea and Balbín, 2003). In general terms, these art complexes in the Upper Tagus Basin-all in caves and at elevations sometimes exceeding $1000 \mathrm{~m}$, contain not only numerous engravings, but also both red and black paintings. The themes are like those of the Duero Basin (horses, red deer, aurochsen and some ibex), but they also more clearly include representations of distinctly cold-climate Pleistocene fauna [wooly rhinoceros and wolverine in Los Casares, bison in La Hoz, reindeer in El Reno (Alcolea and Balbín, 2003)]. The artistic sequence proposed by these authors includes several phases, from the oldest figures in El Reno (attributed to the Gravettian-Solutrean time range) to the middle phase of the Magdalenian for the most recent images in La Hoz and Los Casares. The period of greatest artistic activity is believed to have been the transition between Leroi-Gourhan's Styles III-IV (final Solutrean-early Magdalenian): El Turismo and many of the figures in El Reno, La Hoz and Los Casares (Fig. 25). Other caves in the region have yielded evidence for the presence of Upper Paleolithic living sites (but so far with few archeological excavations) and a very unusual figurine of a wolverine in Jarama II Cave, also in Guadalajara (Jordá et al., 1988, 1989).

The rock art complexes of the interior regions display common, relatively specific problems (conservation, discrimination of post-Paleolithic images, difficulty of archeological contextualization — at least for the moment). Researchers also have to confront such general issues in the study of rock art in SW Europe as the organization and significance of manifestations in the open air or in caves, as well as more concrete ones, such as the observed differences between sites with respect to abstract signs, the hierarchies of techniques in relationship to different animal themes (as, for example, at Siega Verde), the effects of differing types of bedrock surfaces and of technical processes on the formal results (e.g., the stiffer, 


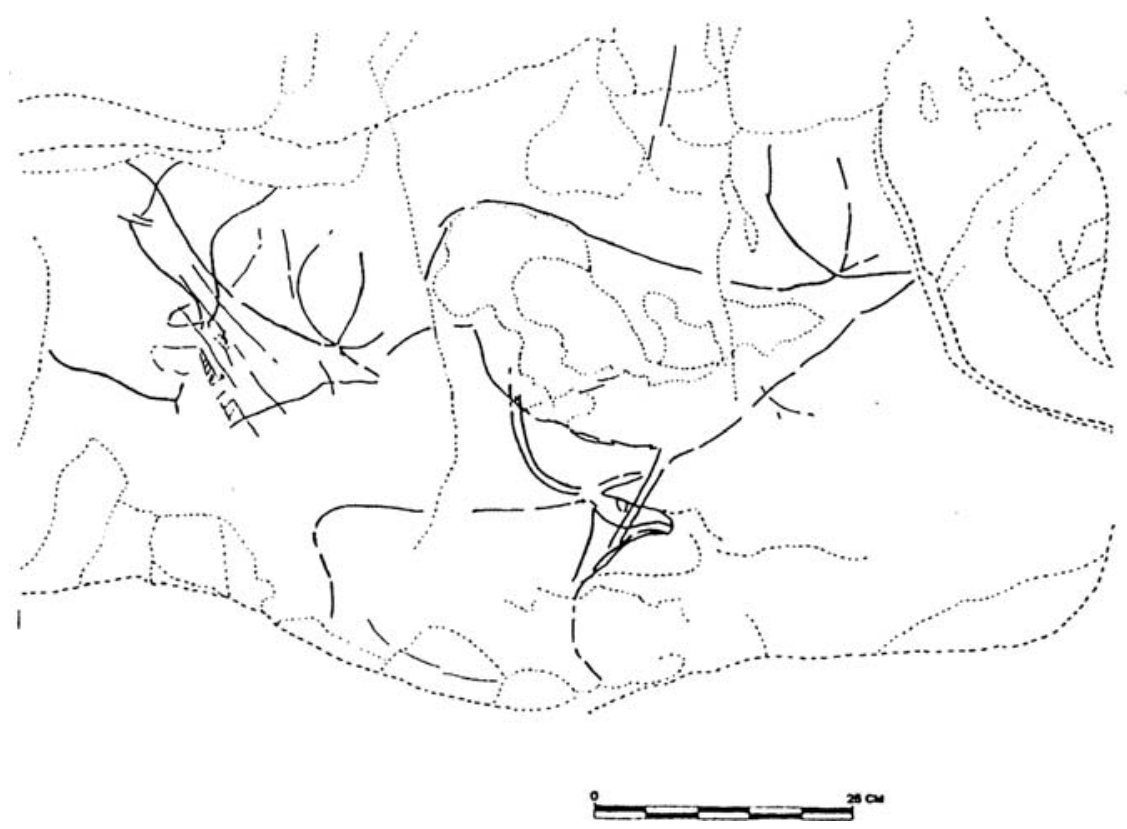

Fig. 25. Figures of red deer and a reindeer (below) engraved on the ceiling of a rear chamber of El Reno Cave in Guadalajara (after Alcolea and Balbín, 2003).

more disproportionate aspect of many of the open-air figures, the lesser potential for using natural relief and breaks on schist and slate surfaces than on the limestone of caves).

Comparative analysis and synthesis of our knowledge of graphic activity among the different regions of the Peninsula are among the goals that research has only begun to explore, although hypotheses are being formulated concerning temporal variation among regions as recorded in parietal art (Sauvet and Wlodarczyk, 2000, 2001). Such an enterprise logically should include the art sites of the meseta-notably the open-air ones of Castile and northern Portugal—whose understanding is key to any Peninsula-wide comparisons and syntheses.

\section{ON THE QUESTION OF “MEANING” (CGS, LGS)}

Over the last century, it seems that each "generation" of Paleolithic rock art specialists has tended to favor one or two dominant "explanations" for the obvious question as to "why" Ice Age people created images on stone. There have been supposedly unique, all-encompassing approaches to interpreting "meaning" that 
have ranged from "art-for-art's-sake," to "hunting magic," to "totemism," to "the symbolism of underlying sexual complementarity," and, currently "shamanism and altered states of consciousness." For commonsense critiques of such ultimately reductive approaches to cave art meaning, we can do little better in the space available here than to refer readers to the now-classic works of Ucko and Rosenfeld (1967) and Bahn and Vertut (1997). (Still valid are the points about the futility of assigning $A$ single significance to rock art made in the excellent review of "approaches in the search for meaning" published in 1987 by M. Conkey.) Despite its current international appeal and undoubted interest as one (albeit ultimately untestable) possibility among many, the shamanistic trance theory of Clottes and Lewis-Williams (1996) has had little impact among Iberian Paleolithic rock art specialists, despite the fact that examples from several sites in this region are used by the authors to illustrate their global magic explanation.

There are two, not mutually exclusive, possible reasons for this observation: 1) Iberian rock art specialists are literally too busy documenting, dating and analyzing both new and old finds (i.e., doing primary fieldwork and essential secondary analytical and comparative research) to spend much time on theorizing; 2) They realize that they are dealing with such a vast diversity of ages, locations, themes, techniques, and styles of rock art as to essentially automatically exclude the plausibility of any single, all-encompassing explanations. As noted in the Introduction of this paper (with reference to the explicitly meaning-seeking works of Freeman and González Echegary), however, this is not to say that, like all archeologists, Iberian rock art specialists do not seek patterns in art themes, techniques, settings and styles that might help provide clues about the nature of the multiple "roles" or conceivable realms of "meaning" that might have been indicated by the various cave and open-air rock arts of the Peninsula, particularly in relationship to the abundant, archeologically contextualized works of portable art that characterize the Upper Paleolithic. It may be fair to state that the present group of authors (and presumably many/most of their Iberian colleagues) would subscribe to the simplistic-sounding, but nonetheless probably true view that Upper Paleolithic Homo sapiens sapiens may have had as many reasons for "doing" what we call "art" as do modern day humans, i.e., from the sacred to the profane, from the public display or monument to the intensely private and personal, from the decorative to the arcane, from demonstrations of grand mastery to casual "doodling" or "graffiti", from the erotic to the ornamental, from magic to messaging, from the illustrative and instructive to the occult, etc. Indeed, just as is true with art of the historic era, "meaning" is in the eye of the beholder-admittedly informed and influenced by his/her cultural milieux of beliefs and experiences. The same images can therefore simultaneously (or over time) hold various different meanings, elicit different reactions or feelings among different (or even the same) viewers. Indeed, it is hard to conceive of any tightly defined meaning for images that would remain invariant over the course of some two dozen millennia. Meaning is a complex, multi-layered, mutable phenomenon-far too vast a subject to be seriously 
discussed in a review article such as this, where the emphasis necessarily has to be on the state of our current knowledge of the facts on the ground such as geographic distributions and on the basics of where we stand with rock art dating, archeological associations and controlled inter-site and intra/inter-regional comparisons. Our general point of view on the question of meaning is summarized in the following paragraphs.

Faced with the splendid images portrayed on so many caves and rock outcrops throughout the Iberian geography, all of us have wondered about their meaning. This is a question which is as logical to ask as it is difficult to answer, since the information available to us - a combination of archeological facts and possible analogies from cultural anthropology - is far to limited and ultimately insufficient. Nonetheless, we can at least make some observations on the nature of the problem. As far as we know, this is an artistic tradition that was developed in SW Europe by Upper Paleolithic hunter-gatherer societies during the course of the last third of the Last Glacial (Oxygen Isotope Stage 2), some 35,000-11,000 radiocarbon years ago. Research into the graphic manifestations of this tradition has revealed the existence of both stylistic changes through time and geographic variations. However, despite this fact, there clearly exists an essential stylistic commonality to this art across time and space that defines a continuous artistic phenomenon. Such relative unity in the art is only understandable in relationship to the kind of society that produced it: fairly complex, mobile forager bands with open marriage systems and a high degree of (direct and/or indirect) long-distance cultural interaction. Persons, certain classes of objects (such as pendants and other personal ornaments), and undoubtedly both ideas and iconographic models circulated widely throughout Europe toward the end of the Paleolithic.

From a general perspective, the figurative images of the Upper Paleolithic are linked with the expansion of anatomically modern humans across the European continent, with systems of social organization, technology and subsistence that were in some respects probably more complex than those of the Neandertals. Rupestral and portable art manifestations, understood at least by us as symbolic in nature, afforded humans with new possibilities for the codification and transmission of information, knowledge and collective beliefs, probably at both practical and spiritual levels. In this way, the art must have played an important role in the affirmation and maintenance of these new and more complicated adaptive systems. In the last analysis, the art became an critical tool in the continuance of the culture-ecological system or lifeway of the Upper Paleolithic people of SW Europe (namely as an instrument of collective affirmation and social cohesion) and as a vehicle of cultural reproduction. This is a basically functionalist view of the art, but only in a very general sense. However specific cases for practical functions of art could be made (e.g., the role in ethological and hunting information storage and instruction advocated by Mithen, 1988), albeit at the peril of engaging in simplistic reductionism. Furthermore, it is likely that many rock art 
sites were critical landmarks in the geographies of Upper Paleolithic bands. This is clearly the case with some of the engraved rock outcrops of the Côa Valley that are located at fords on the river and/or along probable trails. However the landmark character of many cave art sites is also rather obvious, particularly when the art is associated with major habitation deposits (e.g., the caves in the prominent, pyramidally shaped Monte Castillo [El Castillo, La Pasiega, Las Monedas, Las Chimeneas, La Flecha] and those facing the similarly prominent, pyramidally shaped Pico San Vicente [El Mirón, Covalanas, La Haza, La Luz, El Horno and Cullalvera], all in Cantabria). There can be little doubt that these were important places on the landscape for a variety of practical and spiritual reasons - sometimes for long periods of time.

The analysis of the contexts in which the figures were made, as well as of the organization and distribution of the motifs allows us to conclude that this artistic production was the consequence of many different motivations (pace LeroiGourhan, 1965). It seems to us problematic to propose a single meaning for the rock art, as many researchers have done for a long time by attempting to extrapolate from the existence of a common stylistic basis to a unitary class of explanation. The archeological record of any given region clearly shows that there is a great diversity of contexts for the art, a fact that reasonably would suggest the existence of multiple meanings for the art in the context of the cultural landscapes and lives of the creator societies. This diversity can be briefly summarized as follows:

Many caves with Upper Paleolithic living sites also contain graphic manifestations or remnants thereof. That is to say that paintings and engravings were almost always made in places where people lived, or at least further back in the interior of the same caves. And, at least in the case of Foz Côa, archeological sites have been found in varying degrees of proximity to engraved rock outcrops. At the same time it is also true that there are various different kinds of caves that contain art. Some, with hundreds of figures of different styles and motifs made by diverse techniques (e.g., Altamira, La Pasiega, El Castillo, La Garma, the Tito Bustillo-La Lloseta complex, to cite only Cantabrian examples) were clearly reference centers on the landscape for the Paleolithic people who included the artists themselves over many generations. Other caves, also containing important concentrations of parietal art manifestations, but of more homogeneous style and technique, seem to have been used for far shorter periods of time (e.g., Chufín, Covalanas, Las Monedas, Urdiales). At the extreme end of the range, there are also quite a few caves that have only a few figures (or only one) (e.g., La Loja, Herrerías, Santián, Berroberría, La Riera).

Paintings and engravings can be distributed from sunlit cave mouths (e.g., Hornos de la Peña, El Mirón) all the way to cave rears, in sometimes very deep halls and passages that are in complete darkness and often so narrow as to permit access by only one or two people at a time (e.g., Altamira "Cola Caballo," Cullalvera). On the other hand, the Iberian record now clearly shows that rock art was not at all 
restricted to caves, so that the range of places in which such representations were made is indeed complete, from fully exposed, to fully sheltered, from completely sunlit to completely dark, from totally accessible to totally restricted. This suggests a very wide range of social/cultural "functions" and/or "meanings."

The ensembles of figures are also highly varied. One thing that is sure is that the Paleolithic artists carefully chose the subjects represented (i.e., not all the possible subjects were represented, nor do subjects appear in random proportions). Although there are no clearcut statistical relationships between animals hunted and animals represented in specific caves, there are some general relationships between the game species of particular regions and the art of those same regions (e.g., Altuna, 1983, 1994, 2002; González Sainz, 1988). Some of the redundancies in iconographic composition, in specific types of locations, in format and in degree of visibility among some groups of figures, all permit us to suppose that, in many cases, we are dealing with actual symbolic compositions that conveyed coded information that was understandable by the Paleolithic viewers. The groups of figures are not always merely the cumulative products of the adding of figures to a panel at different times. The existence in a region of caves that contain only abstract signs or groups thereof, that are located in similar types of settings also suggest the non-random, symbolically meaningful nature of this kind of art phenomena.

The rock art compositions most probably reflect the Paleolithic hunting peoples' conception of the world, and, in many cases, their transcendent ideas, myths and collective explanations of reality, as expressed in specific aspects of importance to them. The information available to us, which does not allow us to be much more specific, nonetheless does suggest that, given the diversity of locations, formats, visibility, etc., there must have been a wide range of motivations for the making art, from (for example) the manifestation of mythological narratives and beliefs (as implied by redundant compositions), to the accompaniment of initiation ceremonies (as suggested by the locations of some art in deep, difficult-to-reach recesses of caves), to the propitiation of game and its regeneration, to even merely personal affirmation (as in the case of isolated, virtually invisible engravings in very obscure locations). However, the last kind of motivation-personal affirmation (e.g., individual power- or knowledge-seeking "journeys"-may be really anecdotal in the great scheme of Paleolithic rock art, which seems overall to have been a collective graphic system.

\section{CONCLUSIONS (LGS)}

Paleolithic rock art study in Iberia has had a momentous decade and a half, in terms of dating, documentation, distribution, and diversity. What used to be universally the study of cave art has become-with the discovery and validation of Côa (plus nearby Mazouco, and Siega Verde, Domingo Garcia and other Spanish 
loci) - the study of Paleolithic rock art. The gamut of surface types for what we call Upper Paleolithic artistic expression has broadened: deep caves, cave mouths, shallow rock-shelters and open-air outcrops, in addition to loose stone slabs, and even more "portable" bones and teeth. Although the northern Atlantic region of Spain (especially Cantabria and eastern Asturias) remains by far the richest area in terms of both rupestral and mobiliary art manifestations and clearly displays the widest age range for the art, almost all the other regions of the Peninsula (heretofore virtually or completely devoid of such evidence) are "coming on strong". This is especially true of Portugal (and not just Côa in the north, but also in the south) and Andalucía (+ Spanish Extremadura). Levantine Spain-for so long known essentially for the engraved and painted slabs of Parpalló-now is beginning to have a far more abundant and complex record, even if it (as yet) lacks major cave art sites of the order of Nerja, Pileta or Ardales in Málaga. Aragón has one significant cave art locus (Fuente del Trucho), but enough other small sites as to hint at discoveries to come in the Ebro Basin with the increase in active Paleolithic researchers working in the region. Similarly, despite long knowledge of a few classic sites on the mesetas of northern and central Spain (of which researchers often "didn't know what to make," and one of which [Atapuerca-Cueva Mayor] has now been stuck from the roster as an early 20th century forgery (García et al., 2001)), new discoveries and major recent publications have highlighted what a still-limited number of occupation sites indicate, namely that although often inhospitable, the interior was inhabited at certain times (notably in the late Magdalenian) by Upper Paleolithic people. So far, among the major regions of Iberia, only the Northwest (Galicia) — where there is little or no Upper Paleolithic record at all essentially until the very end - and the Northeast (most of Catalonia) where there is a rich record of Upper Paleolithic occupation but (at least for now) with little mobiliary art—are totally devoid of rock art of late Pleistocene type/age (although there is the open-air locus of Fornols Haut in adjacent French Catalonia).

As far as can be determined at the present time (and this is also subject to radical change with new discoveries of the sort that are now regularly "surprising" us and overturning the status quo), there is an uneven Iberian distribution of rock art manifestations in terms of apparent age ranges. Cantabrian Spain seems to have rock art of all periods, although numerically much is still likely to be Magdalenian in age. But there are (growing, but still small) numbers of Early Upper Paleolithic (at least late Aurignacian + Gravettian) figures, based on stratigraphic evidence as at La Viña and $\mathrm{El}$ Conde, ${ }^{14} \mathrm{C}$ dates in Candamo and Calero II, and experimental chronometric dating methods applied at Venta de la Perra, Pondra and La Garma, as well as close physical associations between dated archeological deposits and rupestral images (e.g., the single-component, 22 kya, late Gravettian site and adjacent handprints in Fuente del Salín, Cantabria (Moure and González Morales, 1992)). Mobiliary art (and ornaments) pertaining to the Aurignacian in particular are still extremely scarce, in comparison to SW Germany and SW France. Gravettian sites seem to be particularly abundant in Portugal (e.g., Zilhão 
and Almeida, 2002), where some of the rock art may be attributable to this period.

The Solutrean (justifying the arguments of the late Francisco Jordá against the dogma of the Abbé Breuil on the subject) seems to be fairly well represented in Cantabrian art (both portable and rupestral), but it was in Mediterranean Spain (especially Andalucía) and Portugal that there was a true "explosion" of artistic expression during the Solutrean, in clear parallel with the "boom" in living sites, as these regions became important human refugia during the Last Glacial Maximum. Southern and western Iberia earlier seem to have been refugia for the last Neandertals and, not surprisingly, early Aurignacian sites (and hence art evidence) are absent there. After the Solutrean, Cantabrian Spain (like the French Pyrenees) seems to have become even more densely populated, leading to an eventual expansion onto the northern meseta, as manifested in rock art and living sites (Straus et al. 2000). Magdalenian occupation evidence seems to decrease in Andalucía, but to increase or at least remain stable in Levante and Portugal, although Magdalenian rock art in the southern half of the Peninsula seems to be relatively limited, either because of some change in prehistoric behavior or because of biases in archeological discovery, recognition or identification. There are hints of increased territoriality and artistic regionalization at the end of the Upper Paleolithic. In general, following Jochim (1983), one can hazard to speculate that there is a correlation between periods of relatively dense population packing in particular regions of SW Europe and times of most intensive artistic activity. Beyond the observation of this relationship, there obviously exists the strong possibility that the one may have helped "cause" or promote the latter in terms of a mechanism to affirm social cohesion, a strengthened sense of territorialism, inter-band interaction and negotiation, information storage and transmission related to subsistence, and/or ritual activity in response to relative pressure on food resources. Such moments in time may have included the Gravettian in Portugal, the Solutrean in Mediterranean Spain and the early Magdalenian in Cantabrian Spain.

We are now able to make such sweeping statements (however tentatively) because of the intensive labor of documentation, detailed analyses, technical and stylistic comparisons, and both stratigraphic and chronometric dating by specialists throughout the Peninsula. Serious, systematic AMS radiocarbon dating programs (albeit not free of much-debated problems) have provided solid bases for dating much Solutrean and Magdalenian art, as have direct stratigraphic superpositions of archeological horizons atop engravings at several sites (e.g., La Viña, Ambrosio, Parpalló, El Mirón, Fariseu).

It is clear, albeit with rather tentative beginnings in the late Aurignacian/ Gravettian, that anatomically modern people "marked" the Iberian landscapesboth interior and exterior-where they lived, especially during Isotope Stage 2, and they did so in rough proportion to their demographic densities in the environmentally very diverse regions of the Peninsula. They pictured the animals that lived 
in those environments-especially those upon which they depended daily for food (especially red deer and ibex), as well as those that they more rarely hunted, but which represented subsistence bonanzas when they did (horses, bovines), and other species-some occasionally eaten, others probably rarely or never, but apparently "of interest" (reindeer, roe deer, chamois, mammoth, fish, birds, carnivores). There is considerable congruence between rupestral and portable art in the regions which have both (notable being the cases of the striated engravings of hinds on cave walls and scapulae in the Lower Magdalenian of Cantabria and the parallels between the decorated slabs of Parpalló and bedrock images both in Mediterranean Spain and at Côa). The art of Iberia (especially the Cantabrian region) is also particularly rich in signs, whose meaning(s) elude(s) us even more that those of the animal representations may, but which are amenable to detailed analysis and comparison, both on rock surfaces and on portable objects. In Lewis Binford's parlance (1962), these objects may have had technomic (utilitarian), sociotechnic (socially marking) and/or ideotechnic (ritual) significance (perhaps simultaneously). They, like rock art, can at least help inform us about regional "styles" and perhaps band territories and interrelationships, or even about individual artists or "schools" of expression, in ways that motivated the research of Conkey (1980, 1994), Apellániz (1982, 1991), and others.

What is certain is that, after continuing in the caves of Cantabria during the Last Glacial Interstadial until ca. 11.5 kya (and a bit more recently for figurative portable art in Mediterranean Spain), the artistic activity that had expressed some kind of cohesive and millennial symbol system and world-view finally came to an end. This end came as the world of the last Ice Age hunters and their widespread social networks disappeared for good. The metaphysical world of beliefs could no longer survive in the absence of the physical world-the open glacial landscapes and the herd animals - of which the former had helped people to make sense and to live. The imagined one could not persist long without the real other world. It is the paleoecological context of the disappearance of the Paleolithic rock art that gives us a hint of its previous general significance as an integral part of the worldview and lifeway of Ice Age hunting peoples in SW Europe. Little by little, though we will never know "the truth" about the meaning(s) of Upper Paleolithic art—if such really exist(s)—we are coming to understand "the art" as a diverse phenomenon that developed in parallel with and as an integral part of the processes of human adaptation to the physical and social environments of the late Last Glacial.

\section{ACKNOWLEDGEMENTS}

We wish to thank April Nowell for her invitation to LGS to write this paper-a daunting, but very interesting task that, to be of any value, had to be a collaborative effort between him and the real experts! We also thank two anonymous reviewers 
and the editors of JAMT for their constructive comments, criticism and suggestions. We have attempted to accommodate as many of their points as possible, but without going too far out on fragile interpretive limbs. In our opinion, this would be an exercise as unproductive and futile, as dangerous. Finally, we acknowledge our debt to all our colleagues and predecessors who have spent decades discovering, documenting, dating and debating the nature, age and, indeed, meaning of Iberian rock art, from Altamira to Côa.

\section{REFERENCES}

Abélanet, J., Sacchi, D., and Vilette, P. (1984). L'Art des Cavernes. Ministère de la Culture, Paris, pp. 347-349.

Alcalde del Río, H., Breuil, H., and Sierra, L. (1911). Les Cavernes de la Région Cantabrique. Veuve A. Chêne, Monaco.

Alcolea, J. J., Balbín, R., García Valero, M., and Cruz, L. (1995). La cueva del Turismo (Tamajón, Guadalajara). Arqueología en Guadalajara 12: 127-136.

Alcolea, J. J. (1996). Los Conjuntos Rupestres Paleolíticos al Aire Libre del Valle del Duero: El Yacimiento de Siega Verde (Salamanca). Unpublished doctoral dissertation, Universidad de Alcalá de Henares.

Alcolea, J. J., Balbín, R., García Valero, M., and Jiménez, P. (1997). Nouvelles découvertes d'art rupestre paléolithique dans le centre de la Péninsule Ibérique: la cueva del Reno (Valdesotos, Guadalajara). L'Anthropologie 101: 144-163.

Alcolea, J. J., Balbín, R., Jiménez, P., García Valero, M., and Foyo, A. (2000). La cueva de El Reno (Valdesotos, Guadalajara). Actas do III Congresso de Arqueologia Peninusar, Oporto 2: 525-540

Alcolea, J. J., and Balbín, R. (2003). El arte rupestre del interior peninsular: nuevos elementos para el estudio de su variabilidad regional. In Balbín, R., and Bueno, P. (eds.), El Arte Prehistórico desde los Inicios del Siglo XXI. Amigos de Ribadesella, Ribadesella, pp. 223-253.

Alday, A. (2002). Los últimos cazadores-recolectores de la Iberia interior: la alta-media cuenca del Ebro y la Meseta Norte. Munibe 54: 79-101.

Almagro Gorbea, M. (1976). La cueva del Niño (Albacete) y la cueva de la Griega (Segovia). Trabajos de Prehistoria 28: 9-47.

Altuna, J. (1983). On the relationship between archaeofaunas and parietal art in the caves of the Cantabrian region. In Clutton-Brock, J., and Grigson, C. (eds.), Animals and Archaeology I: Hunters and their Prey. British Archaeological Reports S-163, Oxford, pp. 227-238.

Altuna, J. (1994). La relación fauna consumida-fauna representada en el Paleolítico superior cantábrico. Complutum 5: 303-311.

Altuna, J. (1997). Ekain y Altxerri. Haranburu, San Sebastián.

Altuna, J. (2002). Los animales representados en el arte rupestre de la Península Ibérica. Frecuencias de los mismos. Munibe 54: 21-33.

Altuna, J., and Apellániz, J. M. (1978). Las figuras rupestres paleolíticas de la Cueva de Ekain. Munibe 30: $1-151$.

Apellániz, J. M. (1982). El Arte Prehistórico del País Vasco y sus Vecinos. Desclée de Brouwer, Bilbao.

Apellániz, J. M. (1991). Modelo de Análisis de la Autoría en el Arte Figurativo del Paleolítico. Cuadernos de Arqueología de Deusto 13, Bilbao.

Araújo, A. C., and Lejeune, M. (1995). Gruta do Escoural: Necrópole Neolítica e Arte Rupestre Paleolítica. IPPAR, Lisbon.

Arias, P., Calderón, T., González Sainz, C., Millán, A., Moure, A., Ontañón, R., and Ruiz Idarraga, R. (1998-99). Dataciones absolutas para el arte paleolítico de Venta de la Perra. Kobie 25: 85-92.

Arias, P., González Sainz, C., Moure, A., and Ontañón, R. (1999). La Garma: Un Descenso al Pasado. Gobierno de Cantabria, Santander.

Arias, P., and Ontañón, R. (2005). La Materia del Lenguaje Prehistórico. El Arte Mueble Paleolítico de Cantabria en su Contexto. Gobierno de Cantabria, Santander. 
Aubry, T. (2002). Le contexte archéologique de l'art paléolithique à l'air libre de la vallée du Côa, Portugal. In Sacchi, D. (ed.), L'Art Paléolithique à l'Air Libre. Le Paysage Modifié par l'Image. Groupe Audois d'Etudes Préhistoriques and Géopré, Carcassone, pp. 25-38.

Aubry, T. (2005). Etude de l'approvisionnement en matières premières lithiques d'ensembles archéologiques. In Vialou, D., Renault-Miskovsky, M., and Patou-Mathis, M. (eds.), Comportements des Hommes du Paléolithique Moyen et Supérieur en Europe: Territoires et Milieux. ERAUL 111, Liège, pp. 87-99.

Aubry, T., Chauvière, F.-X., Mangado, X, and Sampaio, J. (2003). Constitution, territoires d'approvisionnement et fonction des sites du Paléolithique supérieur de la basse vallée du Côa (Portugal). In Vasilev, S., Soffer, O., and Kozlowski, J. (eds.), Perceived Landscapes and Built Environments. The Cultural Geography of Late Palaeolithic Eurasia. British Archaeological Reports S-1122, Oxford, pp. 83-92.

Aubry, T., Mangado, X., Sampaio, J., and Sellami, F. (2002). Open-air rock-art, territories and modes of exploitation during the Upper Palaeolithic in the Côa Valley (Portugal). Antiquity 76: 6276.

Aubry, T., and Moura, M. H.(1994). Paleolítico da Serra de Sicó. Trabalhos de Antropologia e Etnologia 34(3/4): 43-60.

Aura, J. E. (2001). Cova de Santa Maira. In Villaverde, V. (ed.), De Neandertales a Cromañones. Los Inicios del Poblamiento Humano en las Tierras Valencianas. Universidad de Valencia, Valencia, pp. 429-432.

Aura, J. E., Jordá, J., González-Tablas, J., Bécares, J., and Sanchidrián, J. L. (1998). Secuencia arqueológica de la Cueva de Nerja: la Sala del Vestibulo. In Sanchidrián, J. L., and Simón, M. D. (eds.), Las Culturas del Pleistoceno Superior en Andalucía. Patronato de la Cueva de Nerja, Málaga, pp. 217-236.

Bahn, P. (1995). Cave art without the caves. Antiquity 69: 231-237.

Bahn, P., and Vertut, J. (1997). Journey through the Ice Age. University of California Press, Berkeley and Los Angeles.

Balbín, R., and Alcolea, J. J. (1994). Arte paleolítico en la Meseta española. Complutum 5: 97-138.

Balbín, R., Alcolea, J. J., and Cruz, L. (1995). Las placas decoradas de la cueva de La Hoz (Sta. María del Espino, Guadalajara). In Jorge, V. O. (ed.), Actas, III Congresso de Arqueología Peninsular. vol. 7 Oporto, pp. 49-63.

Balbín, R., Alcolea, J., and González Pereda, M. (2003). El macizo de Ardines: un lugar mayor del arte paleolítico europeo. In Balbín, R., and Bueno, P. (eds.), El Arte Prehistórico desde los Inicios del Siglo XXI. Asociación Amigos de Ribadesella, Ribadesella, pp. 91-151.

Balbín, R., Alcolea, J. J., and Santonja, M. (1996). Arte Rupestre Paleolítico al Aire Libre de la Cuenca del Duero: Siega Verde y Foz Côa. Fundación Rei Afonso Henriques, Zamora.

Baldellou, V. (1990). Memoria de las actuaciones de 1988 y 1989 en la zona del Río Vero (Huesca). Serie Arqueología Aragonesa. Colección Arqueología y Paleontología 11: 13-18.

Baldomero, A., Cortés, M., Ferrer, J., Marqués, I., and Simón, M. D. (2005). Contextualización mediante cronologías numéricas (AMS, TL y U/Th) de la secuencia tecnocultural de Cueva Bajondillo. In Sanchidrián, J. L., Márquez, A., and Fullola, J. M. (eds.), La Cuenca Mediterránea durante el Paleolítico Superíor. Málaga, pp. 348-356.

Baptista, A. M. (2001a). Ocreza (Envendos, Mação, Portugal central): um novo sítio com arte paleolítica de ar livre. Arkeos 11: 163-192.

Baptista, A. M. (2001b). The Quaternary rock art of the Côa Valley (Portugal). In Zilhão, J., Aubry, T., and Carvalho, A. F. (eds.). Les Premiers Hommes Modernes de la Péninsule Ibérique. Trabalhos de Arqueologia 17, Lisbon, pp. 237-252.

Baptista, A. M. (2004). Arte paleolítica de ar livre no Rio Zêzere (Barroca, Fundão). Eburóbriga 1: $8-16$.

Baptista, A. M. (n.d.). A arte paleolítica de ar livre do Vale do Côa. In Fortea, J. (ed.), Atlas del Arte Paleolítico en la Península Ibérica. Universidad de Oviedo, Oviedo (in press).

Bednarik, R. (1995). The Côa petroglyphs: an obituary to the stylistic dating of Palaeolithic rock-art. Antiquity 69: 877-883.

Beltrán, A. (2002). Art rupestre dans la Grotte du Parpalló. INORA 33: 7-11.

Bicho, N. (2005a). The extinction of Neanderthals and the emergence of the Upper Palaeolithic in Portugal. Promontoria 3: 173-228. 
Bicho, N. (2005b). Upper Pleistocene human occupation of southern Portugal. Paper presented at the VI Iberian Quaternary Meeting, Gibraltar.

Binford, L. R. (1962). Archaeology as anthropology. American Antiquity 28: 217-225.

Bischoff, J., García Diez, M., González Morales, M., and Sharp, W. (2003). Aplicación del método de series de uranio al grafismo rupestre de estilo paleolítico: el caso de la cavidad de Covalanas. Veleia 20: $143-150$.

Breuil, H., and Obermaier, H. (1935). The Cave of Altamira at Santillana del Mar, Spain. Tipografía de Archivos, Madrid.

Bueno, P., and Balbín, R. (2001). Le sacré et le profane: notes pour l'interprétation des graphies préhistoriques péninsulaires. Revue Archéologique de l'Ouest, 9 (Suppl): 141-148.

Bueno, P., Balbín, R., and Alcolea, J. (2003). Prehistoria del lenguaje en las sociedades cazadoras y productoras del sur de Europa. In Balbín, R., and Bueno, P. (eds.), El Arte Prehistórico desde los Inicios del Siglo XXI. Asociación Amigos de Ribadesella, Ribadesella, pp. 13-22.

Cacho, C., Fumanal, M. P., López, P., López, J. A., Pérez Ripoll, M., Martínez Valle, R., Uzquiano, P., Arnanz, A., Sánchez Marco, A., Sevilla, P., Morales, A., Roselló, E., Garralda, M. D., and GarcíaCarrillo, M. (1996). El Tossal de la Roca (Vall d'Alcalà, Alicante). Reconstrucción paleoambiental y cultural de la transición del Tardiglaciar al Holoceno inicial. Recerques del Museu d'Alcoi 4: 11-101.

Cacho, C., Jordá, J., de la Torre, I., and Sainz, J. Y. (2001). El Tossal de la Roca (Alicante). Nuevos datos sobre el Magdaleniense mediterráneo de la Península Ibérica. Trabajos de Prehistoria 58: 71-93.

Cantalejo, P., Maura, R., Espejo, M., Ramos, J., Medianero, J., Aranda, A., Mora, J., Castañeda, V., and Becerra, M. (2003). La cueva de Ardales. Primeras agregaciones gráficas paleolíticas en la Sala de las Estrellas. Mainake 25: 231-248.

Cantalejo, P., Maura, R., Espejo, M., Ramos, J., Medianero, J., Aranda, A., Castañeda, V., and Cáceres, I. (2004). Cueva de Ardales (Málaga): testimonios gráficos de la frecuentación por formaciones sociales de cazadores-recolectores durante el Pleistoceno superior. In Sociedades Recolectores y Primeros Productores. Actas de las Jornadas Temáticas Andaluzas de Arqueología, Ronda, pp. $123-138$

Cantalejo, P., Maura, R., Espejo, M., Ramos, J., Medianero, J., Aranda, A., and Durán, J. (2006). La Cueva de Ardales: Arte Prehistórico y Ocupación en el Paleolítico Superior. Diputación Provincial de Málaga, Málaga.

Carvalho, A. F., and Baptista, A. M. (2002). Late prehistory and rock-art in the Côa Valley (northeast Portugal). Paper presented at the 67th Annual Meeting of the of the Society for American Archaeology, Denver.

Chalmin, E., Menu, M., and Altuna, J. (2002). Les matières picturales de la grotte d'Ekain. Munibe 54: $3-51$.

Clottes, J. (1998). The "three Cs": fresh avenues towards European Palaeolithic art. In Chippindale, C., and Taçon, P. (eds.), The Archaeology of Rock-Art. Cambridge University Press, Cambridge, pp.112-129.

Clottes, J., and Lewis-Williams, D. (1996). Chamanes de la Préhistoire. Éditions du Seuil, Paris.

Collado, H. (2002). Arte rupestre en la presa de Alqueva. El conjunto de grabados del Molino Manzanez (Alconchel-Cheles, Badajoz). Al-Madan II series, 11: 196-201.

Collado, H., Girón, M., and Fernández, M. (2003). Paleolithic rock art in Molino Manzanez area (Alconchel-Cheles, Badajoz, Spanien). Quartaer, xx: 1-21.

Conkey, M. (1980). The identification of hunter-gatherer aggregation sites: the case of Altamira. Current Anthropology 21: 609-630.

Conkey, M. (1987). New approaches in the search for meaning? A review of research in "Paleolithic art". Journal of Field Archaeology 14: 413-430.

Conkey, M. (1994). Estructuras del diseño y grabado en el Magdaleniense de la España cantábrica: algunas ideas retrospectivas. In Lasheras, J. A. (ed.), Homenaje al Dr. Joaquín González Echegaray. Museo y Centro de Investigación de Altamira, Monografías 17, Madrid, pp. 311-323.

Corchón, M. S. (1997). La Cueva de la Griega (Segovia). Memorias Arqueológicas de Castilla y León 3, Zamora.

Corchón, M. S. (2002). El Tardiglaciar y la transición al Postglaciar en la Meseta norte española. Zephyrus 55: 85-142. 
Corchón, M. S., Valladas, H., Bécares, J., Arnold, M., Tisnerat, N., and Cachier, H. (1996). Datación de las pinturas y revisión del arte prehistórico de Cueva Palomera (Ojo Guareña, Burgos, Spain). Zephyrus 49: 37-60.

Córdoba, B., and Vega, G. (1988). El Paleolítico de la Sierra del Segura: proyecto de investigación. Actas del Congreso de Historia de Castilla-La Mancha Toledo, 2: 79-85.

D’Errico, F., and Possenti, M. (1999). L'art mobilier épipaléolithique de la Méditerranée occidentale: comparaisons thématiques et technologiques. In Sacchi, D. (ed.), XXIX Congrès Préhistorique de France. Les Facies Leptolithiques du Nord-Ouest Méditerranéen: Milieux Naturels et Culturels. Société Préhistorique Française, Carcassonne, pp. 93-116.

Dorn, R. (1997). Constraining the age of the Côa valley (Portugal) engravings with radiocarbon dating. Antiquity 71: 105-115.

Fernández, J., Guillem, P. M., Martínez Valle, R., and García, R. M. (2002). El contexto arqueológico de la Cova dels Cavalls: poblamiento prehistórico y arte rupestre en el tramo superior del Riu de les Coves. In Martínez, R. and Villverde, V. (eds.), La Cova dels Cavalls en el Barranc de la Valtorta. Monografías del Instituto de Arte Rupestre, Valencia, pp. 49-73.

Fortea, J. (1973). Los Complejos Microlaminares y Geométricos del Epipaleolítico Mediterráneo Español. Memorias del Seminario de Prehistoria y Arqueología 4, Salamanca.

Fortea, J. (1978). Arte paleolítico del Mediterráneo español. Trabajos de Prehistora 35: 9-149.

Fortea, J. (1994). Los "santuarios" exteriores en el Paleolítico cantábrico. Complutum 5: 203-226.

Fortea, J. (1995). El Bosque. Excavaciones Arqueológicas en Asturias 1991-1994. Principado de Asturias, Oviedo, pp. 271-274.

Fortea, J. (2000). Los comienzos del arte paleolítico en Asturias. Zephyrus 53-54: 177/216.

Fortea, J. (2002). Trente-neuf dates C14-SMA pour l'art pariétal paléolithique des Asturies. Bulletin de la Société Préhistorique Ariège-Pyrénées 59: 7-28.

Fortea, J. (2005). La plus ancienne production artistique du Paléolithique ibérique. In Broglio, A., and Dalmeri, G. (eds.), Pitture Paleolitiche nelle Prealpi Venete. Museo Civica di Storia Naturale, Verona, pp. 89-99.

Fortea, J. (ed.) (n.d.). Atlas del Arte Paleolítico en la Península Ibérica. Universidad de Oviedo, Oviedo (in preparation).

Fortea, J., Fritz, C., García, M., Sanchidrián, J. L., Sauvet, G., Tosello, G. (2004a). L’art pariétal paléolithique à l'épreuve du style et du Carbone-14. In Otte, M. (ed.), La Spiritualité. ERAUL 106, Liège, pp. 163-175.

Fortea, J., and Quintanal, J. (1995). Santo Adriano. Excavaciones Arqueológicas en Asturias 19911994. Principado de Asturias, Oviedo, pp. 275-276.

Fortea, J., Rasilla, M., and Rodríguez Otero, V. (2004b). L'art pariétal et la séquence archéologique paléolithique de la grotte de Llonín. Bulletin de la Société Préhistorique Ariège-Pyrénées 59: 7-29

Fortea, J., Rodríguez Asensio, J., and Ríos, S. (1999). La grotte de Los Torneiros. INORA 24: 8-11.

Fortea, J., Rodríguez Otero, V., Hoyos, M., Federación Asturiana de Espeleología, Valladas, H., and Torres, T. (1995). Covaciella. Excavaciones Arqueológicas en Asturias 1991-1994. Principado de Asturias, Oviedo, pp. 258-270.

Freeman, L. G. (2005). La cueva como santuario paleolítico. In Lasheras, J. A., and González Echegaray, J. (eds.), El Significado del Arte Paleolítico. Ministerio de Cultura, Madrid, pp. 163-179.

Freeman, L. G., González Echegaray, J., Bernaldo de Quirós, F., and Ogden, J. (1987). Altamira Revisited and Other Essays on Early Art. Institute for Prehistoric Investigations, Chicago and Santander.

Freeman, L. G., and Gonzalez Echegaray, J. (2001). La Grotte d'Altamira. La Maison des Roches, Paris.

Fullola, J. M., and Viñas, R. (1988). Dernières découvertes dans l'art préhistorique de Catalogne. L'Anthropologie 92: 123-132.

Gárate, D., Laval, E., and Menu, M. (2004). Etude de la matière colorante de la grotte d'Arenaza. L'Anthropologie 108: 251-265.

García, M., and Aubry, T. (2002). Grafismo mueble en el Valle de Côa (Vila Nova de Foz Côa, Portugal): la estación arqueológica de Fariseu. Zephyrus 55: 157-182.

García Diez, M. (2001). Comportamiento Gráfico durante el Paleolítico Superior en el Alto Asón. Unpublished doctoral dissertation, Universidad del País Vasco, Vitoria. 
García Diez, M. (2004). El grafisme moble del Molí del Salt I la figuració moble durant el Tardiglaciar en el vessant mediterrani de la Península Ibèrica. In Vaquero, M. (ed.), Els Darrers Caçadorsrecol.lectors de la Conca de Barberà: El Jaciment del Moli del Salt. Publicacions del Museu de Montblanc 5, pp. 211-264.

García Diez, M., and Eguizábal, J. (2003). La Cueva de Covalanas. Gobierno de Cantabria, Santander.

García Diez, M., González Morales, M., and Straus, L. G. (n.d.). Grafismo rupestre paleolítico de la Cueva de El Mirón. Unpublished manuscript.

García, M., Ortega, A. I., Martín, M. A., Hortolà, P., and Zuluaga, M. C. (2001). Arte rupestre de estilo paleolítico del Portalón de Cueva Mayor de la Sierra de Atapuerca (Ibeas de Juarros, Burgos): ¿cronología paleolítica o contemporánea? Trabajos de Prehistoria 58: 153-169.

Glory, A., Vaultier, M., and Santos, M. F. (1965). La grotte ornée d'Escoural (Portugal). Bulletin de la Société Préhistorique Française 62: 110-117.

González Echegaray, J. (2005). La interpretación mágica del arte paleolítico. In Lasheras, J. A., and González Echegaray, J. (eds.), El Significado del Arte Paleolítico. Ministerio de Cultura, Madrid, pp. 229-245.

González Echegaray, J., and González Sainz, C. (1994). Conjuntos rupestres paleolíticos de la cornisa cantábrica. Complutum 5: 21-43.

González Morales, M. (1997). When the beasts go marchin' out! The end of Pleistocene art in Cantabrian Spain. In Conkey, M., Soffer, O., Stratmann, D., and Jablonski, N. (eds.), Beyond Art: Pleistocene image and symbol. Memoirs of the California Academy of Sciences 23, San Francisco, pp. 189-199.

González Morales, M., and Straus, L. G. (2000). Parietal engravings in Magdalenian stratigraphic context in El Mirón Cave. INORA 27: 1-5.

González Morales, M., Straus, L. G., and Marín, A. B. (2005). Omóplato grabado en cabeza de cierva y posible bovino, El Mirón. In Arias, P., and Ontañón, R. (eds.), La Materia del Lenguaje Prehistórico. Gobierno de Cantabria, Santander, pp. 172-173.

González Morales, M., Straus, L. G., and Marín, A. B. (n.d.). Los omóplatos decorados magdalenienses de la Cueva del Mirón y su relación con las Cuevas del Castillo, Altamira y El Juyo. In Baquedano, E., and Maillo, J. M. (eds.), Homenaje a Victoria Cabrera. Zona Arqueológica, Alcalá de Henares (in press).

González Sainz, C. (1988). Le fait artistique à la fin du Paléolithique: quelques réflexions. Bulletin de la Société Préhistorique Ariège-Pyrénées 43: 35-62.

González Sainz, C. (1995). 13.000-11.000 BP. El final de la época Magdaleniense en la región cantábrica. In Moure, A., and González Sainz, C. (eds.), El Final del Paleolítico Cantábrico. Universidad de Cantabria, Santander, pp. 159-197.

González Sainz, C. (2002). Unidad y variedad de la región cantábrica y sus manifestaciones artísticas. In Las Cuevas con Arte Paleolítico en Cantabria. ACDPS, Santander, pp. 28-45.

González Sainz, C. (2003). El conjunto parietal de la galería inferior de La Garma (Omoño, Cantabria). Avance a su organización interna. In Balbín, R., and Bueno, P. (eds.), El Arte Prehistórico desde los Inicios del Siglo XXI. Asociación Amigos de Ribadesella, Ribadesella, pp. 201-222.

González Sainz, C. (n.d.). Sobre la actividad gráfica magdaleniense en la región cantábrica. Datación y modificacines iconográficas. In Bicho, N. (ed.), Actas do IV Congresso de Arqueologia Peninsular. Faro (in press).

González Sainz, C., and Cacho, R. (2002). La Llosa. In Las Cuevas con Arte Paleolítico en Cantabria. ACDPS, Santander, pp. 201-202.

González Sainz, C., Cacho, R., and Fukazawa, T. (2003). Arte Paleolítico en la Región Cantábrica. Base de Datos Multimedia Photo VR. Gobierno de Cantabria, Santander.

González Sainz, C., and San Miguel, C. (2001). Las Cuevas del Desfiladero. Arte Rupestre Paleolítico en el Valle del Río Carranza. Gobierno de Cantabria, Santander.

Gorrotxategi, X. (2000). Arte Paleolítico Parietal de Bizkaia. Kobie. Supplement 2, Diputación Foral de Vizcaya, Bilbao.

Graziosi, P. (1956). L'Arte dell' Antica età della Pietra. Florence.

Graziosi, P. (1964). L'art paléolithique de la "province artistique méditerranéenne" et ses influences dans les temps postpaléolithiques. In Pericot, L., and Ripoll, E. (eds.), Prehistoric Art of the Western Mediterranean and the Sahara. Viking Fund Publications in Anthropology 39, New York, pp. 35-46.

Graziosi, P. (1973). L'Arte Preistorica in Italia. Sanzoni, Florence. 
Hernández, M. S., Ferrer, S., and Catalá, E. (1988). Arte Rupestre en Alicante. Fundación Banco Exterior de España, Alicante.

Jimeno, A., Fernández Moreno, J., Gómez Barrera, J. A., and Galindo, M. (1990). Arte paleolítico en la provincia de Soria: la placa de Villalba. Numantia 3: 9-50.

Jochim, M. (1983). Paleolithic cave art: some ecological speculations. In Bailey, G. (ed.), HunterGatherer Economy in Prehistory. Cambridge University Press, Cambridge, pp. 212-219.

Jordá, J. F., García Valero, M., Adan, G., and Sánchez Chillón, B. (1988-89). Una pieza de arte mueble magdaleniense: el glotón de la cueva de Jarama II (Valdesotos, Guadalajara). Ars Praehistorica 7-8: 107-122.

Jorge, S. O., Jorge, V. O., Almeida, C., Sanches, M., and Soeiro, M. (1981). Gravuras rupestres de Mazouco (Freixo de Espada de Cintra). Arqueologia 3: 3-12.

Juaneda, A. (1988). Avance al estudio de los grabados parietales de la cueva de La Peña La Morca (Coviella, Cangas de Onis). Boletín del Instituto de Estudios Asturianos 128: 875-885.

Lasheras, J. A., Montes, R., Rasines, P., and Muñoz, E. (2003). Catálogo de la Cornisa Cantábrica y Navarra. In Catálogo del Arte Prehistórico de la Península Ibérica y de la España Insular, Real Academica de Cultura Valenciana, Valencia, vol. I, pp. Xx-Xx.

Lasheras, J. A., Montes, R., Rasines, P., Muñoz, E., Fatás, P., and de las Heras, C. (2005). La Grotte de Cualventi (Oreña, Alfoz de Lloreda, Cantabrie): un nouveau site d'art paléolithique en Espagne cantabrique. INORA 42: 11-17.

Leroi-Gourhan, A. (1965). Préhistoire de l'Art Occidental. Mazenod, Paris.

Lorblanchet, M. (1995). Les Grottes de la Préhistoire. Nouveaux Regards. Errance, Paris.

Martín, E., and Moure, J. (1981). El grabado de estilo paleolítico de Domingo Garcia (Segovia). Trabajos de Prehistoria 38: 97-105.

Martínez Andreu, M. (1996). El Paleolítico superior. In Eiroa, J. J. (ed.), Prehistoria de la Región de Murcia. Murcia, pp. 67-113.

Martínez, R., Guillem, P., and Villaverde, V. (2003). Las figuras grabadas de estilo paleolítico del Abric d'en Melià (Castelló). In Balbín, R., and Bueno, P. (eds.), El Arte Prehistórico desde los Inicios del Siglo XXI. Asociación Amigos de Ribadesella, Ribadesella, pp. 279-290.

Mithen, S. (1988). Looking and learning: Upper Palaeolithic art and information gathering. World Archaeology 19: 297-327.

Montes, R., Muñoz, E., and Morlote, J. (2001). La cueva de Los Moros de San Vitores (Medio Cudeyo). Una nueva estación de arte rupestre paleolítico en Cantabria. Trabajos de Prehistoria 58: $129-142$.

Montes, R., Muñoz, E., and Morlote, J. (2002). Los grabados rupestres paleolíticos de la cueva de La Luz (Ramales de la Victoria, Cantabria). Nivel Cero 10: 23-32.

Montes, R., Muñoz, E., and Morlote J. (2005). Cueva Urdiales (Castro Urdiales, Cantabria). Estudio Geo-arqueológico y Arte Rupestre Paleolítico. Ayuntamiento de Castro Urdiales, Castro Urdiales.

Moro, O., and González Morales, M. (2004). Towards a genealogy of the concept of "Paleolithic mobiliary art". Journal of Anthropological Research 60: 321-339.

Moure, A., and González Morales, M. (1992). Radiocarbon dating of a decorated area in the Fuente del Salín Cave in Spain. INORA 3: 1-2.

Moure, A., González Sainz, C., Bernaldo de Quirós, F., and Cabrera, V. (1996). Dataciones absolutas de pigmentos en cuevas cantábricas: Altamira, El Castillo, Chimeneas y Las Monedas. In Moure, A. (ed.), "El Hombre Fósil" 80 Años Después. Universidad de Cantabria, Santander.

Moure, A., and González Sainz, C. (2000). Cronología del arte paleolítico cantábrico: últimas aportaciones y estado actual de la cuestión. In Jorge, V. O. (ed.), Actas do III Congresso de Arqueologia Peninsular. Oporto, pp. 464-473.

Muñoz, E. (2002a). Calero II. In Las Cuevas con Arte Paleolítico en Cantabria. ACDPS, Santander, pp. $151-154$.

Muñoz, E. (2002b). Morín. In Las Cuevas con Arte Paleolítico en Cantabria. ACDPS, Santander, p. 322.

Mussi, M. (2001). Earliest Italy. Plenum Press, New York.

Olaria, C. (1999). Cova Matutano (Vilafamés, Castellón). Monografies de Prehistória I Arqueología Castgellonenques 5, Castellón.

Otte, M., and Silva, A. C., (eds.) (1996). Recherches Préhistoriques à la Grotte d'Escoural, Portugal. ERAUL 65, Liège. 
Palma di Cesnola, A. (2001). Le Paléolithique Supérieur en Italie. Jérôme Millon, Grenoble.

Pericot, L. (1942). La Cueva del Parpalló. Instituto Diego Velázquez, CSIC, Madrid.

Phillips, F., Flinsch, M., Elmore, D., and Sharma, P. (1997). Maximum ages of the Côa valley (Portugal) engravings measured with ${ }^{36} \mathrm{Cl}$. Antiquity 71: 100-104.

Ripoll, E. (1965). Una pintura de tipo paleolítico en la Sierra de Montsiá (Tarragona) y su posible relación con los origenes de arte levantino. In Ripoll, E. (ed.), Miscelánea en Homenaje al Abate H. Breuil. vol. 2 Diputación Provincial de Barcelona, Barcelona, pp. 297-302.

Ripoll, S. (1988). La Cueva de Ambrosio (Vélez Blanco, Almería) y su Posición Cronoestratigráfica en el Mediterráneo Occidental. British Archaeological Reports S-462, Oxford.

Ripoll, S., Municio, L. (1999). Domingo García. Arte Rupestre Paleolítico al Aire Libre en la Meseta Castellana. Arqueología en Castilla y León 8, Salamanca.

Ripoll, S., and Muñoz Ibañez, F. (2003). El arte mueble del yacimiento de la Peña de Estebanvela (Estebanvela-Ayllón, Segovia). In Balbín, R., and Bueno, P. (eds.), El Arte Rupestre desde los Inicios del Siglo XXI. Amigos de Ribadesella, Ribadesella, pp. 263-278.

Ripoll, S., Ripoll, E., and Collado, H. (1999). Maltravieso. El Santuario Extremeño de las Manos. Cáceres.

Ruiz Cobo, J., and Smith, P. (eds.). (2003). La Cueva de Cofresnedo en el Valle de Matienzo. Acutaciones Arqueológicas 1996-2001. Gobierno de Cantabria, Santander.

Sacchi, D., Abélanet, J., Brule, J., Massiac, Y., Rubiella, C., and Vilette, P. (1988). Les gravures rupestres de Fornols-Haut, Pyrénées-Orientales. L'Anthropologie 92: 87-100.

Salmerón, J., and Lomba, J. (1996). El arte rupestre paleolítico. In Lomba, J., Martínez, M., Montes, R., and Salmerón, J. (eds.), Historia de Cieza vol. 1. Cieza, pp. 71-89.

Salmerón, J., Lomba, J., Cano, M., and Grupo Los Almadenes (1995). Avance al estudio del arte rupestre paleolítico en Murcia: las Cuevas de Jorge, Las Cabras y El Arco. Actas del XXIII Congreso Nacional de Arqueología, pp. 201-216.

Sanchidrián, J. L. (1986). Arte prehistórico de la Cueva de Nerja. In Jordá, J. F. (ed.), Trabajos Sobre la Cueva de Nerja. I. La Prehistória de la Cueva de Nerja (Málaga). Patronato de la Cueva de Nerja, Málaga, pp. 283-330.

Sanchidrián, J. L. (1994a). Trabajos sobre la Cueva de Nerja 4. Arte Rupestre de la Cueva de Nerja. Patronato de la Cueva de Nerja, Málaga.

Sanchidrián, J. L. (1994b). Arte paleolítico de la zona meridional de la Península Ibérica. Complutum 5: $163-195$.

Sanchidrián, J. L. (1997). Propuesta de la secuencia figurativa en la Cueva de la Pileta. In Fullola, J. M., and Soler, N. (eds.), El Mon Mediterrani despres del Pleniglacial. Centre d'Investigacions Arqueológiques, Sèrie Monogràfica 17, Girona, pp. 411-430.

Sanchidrián, J. L. (2000a). Panorama actual del arte paleolítico en Andalucía. In Jorge, V. O. (ed.), Actas do $3^{\circ}$ Congresso de Arqueologia Peninsular. vol. 2 Oporto, pp. 541-554.

Sanchidrián, J. L. (2000b). El sud també existeix. Visió de l'art paleolític a Andalucía. Cota Zero 16: 24-34.

Sanchidrián, J. L., and Márquez, A. (2003). Radiodataciones y sus repercusiones en el arte prehistórico malagueño. Mainake 25: 275-292.

Sanchidrián, J. L., Márquez, A., Valladas, H., and Tisnerat, N. (2001). Dates directes pour l'art rupestre d'Andalousie (Espagne). INORA 29: 15-19.

Santos, M. F. (1964). Vestígios de pinturas rupestres descobertas na Gruta do Escoural. O Arqueólogo Português, II Series 5: 5-47.

Santos, M. F., Gomes, M., and Monteiro, J. (1981). Descobertas de arte rupestre na Gruta do Escoural (Évora, Portugal). In Almagro, M. (ed.), Altamira Simposium. Ministerio de Cultura, Madrid, pp. 205-242.

Sanz de Sautuola, M. (1880). Breves Apuntes sobre algunos Objetos Prehistóricos de la Provincia de Santander. Telesforo Martínez, Santander.

Saura, P., and Beltrán, A. (1998). Altamira. Seuil, Paris.

Sauvet, G., and Wlodarczyk, A. (2000-01). L'art pariétal, miroir des sociétés paléolithiques. Zephyrus 53-54: 217-240.

Schwendler, R. (2005). Magdalenian perforated bone disks in geographic and social contexts. In Dujardin, V. (ed.), Industrie Osseuse et Parures du Solutréen au Magdalénien en Europe. Mémoire de la Société Préhistorique Française 39, Paris. 
Serna, A. (2002a). Alto de Peñajorao. In Las Cuevas con Arte Paleolítico en Cantabria. ACDPS, Santander, p. 321.

Serna, A. (2002b). Los Santos. In Las Cuevas con Arte Paleolítico en Cantabria. ACDPS, Santander, p. 326.

Sieveking, A. (1983). Style and regional grouping in Magdalenian cave art. Bulletin of the Institute of Archaeology 16: 95-109.

Straus, L. G. (1982). Observations on Upper Paleolithic art: old problems and new directions. Zephyrus 34-35: 71-80.

Straus, L. G. (1987). The Paleolithic cave art of Vasco-Cantabrian Spain. Oxford Journal of Archaeology 6: $149-163$.

Straus, L. G. (1992). Iberia before the Iberians. University of New Mexico Press, Albuquerque.

Straus, L. G. (2000). A quarter-century of research on the Solutrean of Vasco-Cantabria, Iberia and beyond. Journal of Anthropological Research 56: 39-58.

Straus, L. G., Bicho, N., and Winegardner, A. (2000). Mapping the Upper Paleolithic regions of Ibería. Antiquity 74: 553-566.

Tarriño, A. (2001). El Silex de la Cuenca Vasco Cantábrica y del Pireneo Navarro: Caracterización y su Aprovechamiento en la Prehistoria. Unpublished doctoral dissertation, Universidad de País Vasco, Vitoria.

Tarriño, A. (2001). El Silex de la Cuenca Vasco Cantábrica y del Pireneo Navarro: Caracterización y su Aprovechamiento en la Prehistoria. Unpublished doctoral dissertation, Universidad de País Vasco, Vitoria.

Ucko, P., and Rosenfeld, A. (1967). Palaeolithic Cave Art. World University Library, London.

Utrilla, P. (1987). La Cueva de Peña Miel. Excavaciones Arqueológicas en España 154, Madrid.

Utrilla, P. (1990). Aragón/litoral mediterráneo. Relaciones durante el Paleolítico. In P. Utrilla. (ed.), Aragón/Litoral Mediterráneo: Intercambios Culturales Durante la Prehistoria. Institución Fernando el Católico, Zaragoza, pp. 29-64.

Utrilla, P. (1995). El valle del Ebro durante el Tardiglacial y comienzos del Holoceno. In Moure, A., and González Sainz, C. (eds.), El Final del Paleolítico Cantábrico. Universidad de Cantabria, Santander, pp. 281-311.

Utrilla, P. (2000a). El Arte Rupestre en Aragón. Caja de Ahorros de la Inmaculada de Aragón, Zaragoza.

Utrilla, P. (2000b). El Paleolítico en el valle medio del Ebro: una revista de prensa en el cambio del milenio. SPAL 9: 81-108.

Utrilla, P., Villaverde, V., and Martínez, R. (2001). Les gravures rupestres de Roca Hernando (Cabra de Mora, Teruel). In Zilhão, J, Aubry, T., and Carvalho, A. F. (eds.), Les Premiers Hommes Modernes de la Péninsule Ibérique. Trabalhos de Arqueologia 17, Lisbon, pp. 161-174.

Valle, A. (2002). San Juan de Socueva. In Las Cuevas con Arte Paleolítico en Cantabria. ACDPS, Santander, pp. 229-232.

Vaquero, M. (ed.) (2004). Els Darrers Caçadors-Recol.lectors de la Conca de Barberà: El Jaciment del Moli del Salt (Vimboni). Excavacions 1999-2003. Publicacions del Museu de Montblanc 5.

Vega, L. G. (1993). Excavaciones en el Abrigo del Molino del Vadico (Yeste, Albacete). Jornadas de Arqueología Albacetense en la Universidad Autónoma de Madrid. Madrid, pp. 19-32.

Villaverde, V. (1994a). Arte Paleolítico de la Cova del Parpalló. Servei d'Investigació Prehistórica, Valencia.

Villaverde, V. (1994b). Arte mueble de la España mediterránea: algunas consideraciones teóricas y breve síntesis. Complutum 5: 139-162.

Villaverde, V. (2001). El arte de los cazadores y recolectores del Paleolítico superior. In Villaverde, V. (ed.), De Neandertales a Cromañones. El Inicio del Poblamiento Humano en las Tierras Valencianas. Universitat de Valencia, Valencia, pp. 331-366.

Villaverde, V. (2004). Arte mueble paleolítico en el Mediterráneo occidental: contexto y diversidad regional. In Arias, P., and Ontañón, R. (eds.), La Materia del Lenguaje Prehistórico. Gobierno de Cantabria, Santander, pp. 67-84.

Villaverde, V. (2005a). Arte paleolítico mediterráneo: de la Cueva de la Pileeta a la Cova de les Meravelles. In Hernández, M. S., and Soler, J. A. (eds.), Arte Rupestre en la España Mediterránea. Alicante, pp. 17-44.

Villaverde, V. (2005b). Art paléolithique de la Méditerranée espagnole: arguments contre son rattachement à une province artistique méditerranéenne. In Vialou, D., Renault-Miskovsky, J., and 
Patou-Mathis, M. (eds.). Comportements des Hommes du Paléolithique Moyern et Supérieur en Europe: Territoires et Milieux. ERAUL 111, Liège, pp. 163-176.

Villaverde, V., and Roman, D. (2004). Avance al estudio de los niveles gravetienses de la Cova de les Cendres. Archivo de Prehistoria Levantina 25: 19-59.

Villaverde, V., Aura, J. E., and Barton, C. M. (1998). The Upper Paleolithic in Mediterranean Spain: a review of current evidence. Journal of World Prehistory 12: 121-198.

Villaverde, V., Cardona, J., and Martínez-Valle, R. (n.d.). Los grabados paleolíticos de la Cova de les Meravelles (Gandia, Valencia). In El Paleolítico Superior en la Europa Mediterránea. Patronato de la Cueva de Nerja, Nerja (in press).

Watchman, A. (1996). A review of the theory and assumptions in the AMS dating of the Foz Côa petroglyphs. Rock Art Research 13: 21-30.

Zampetti, D., and Mussi, M. (1999). En deçà et au-delà des Alpes. L'art paléolithique italien dans son contexte européen. In Sacchi, D. (ed.), XXIX Congrès Préhistorique de France. Les Facies Leptolithiques du Nord-Ouest Méditerranéen: Milieux Naturels et Culturels. Société Préhistorique Française, Carcassonne, pp. 41-47.

Zilhão, J. (1988). Plaquette gravée du Solutréen supérieur de la Gruta do Caldeirão (Tomar, Portugal). Bulletin de la Société Préhistorique Française 85: 105-108.

Zilhão, J. (1995). The age of the Côa valley (Portugal) rock-art: validation of archaeological dating to the Palaeolithic and refutation of "scientific" dating to historic or proto-historic times. Antiquity 69: 883-901.

Zilhão, J. (1997a). O Paleolítico Superior da Estremadura Portuguesa. Colibri, Lisbon.

Zilhão, J. (1997b). Arte Rupestre e Pré-História do Vale do Côa. Trabalhos de 1995-1996. Ministério da Cultura, Lisbon.

Zilhão, J. (2001). Le Paléolithique supérieur du Portugal. Bilan quinquennal. In Noiret, P. (ed.), Le Paléolithique Supérieur Européen. Bilan Quinquennal 1996-2001. ERAUL 97, Liège, pp. 161171.

Zilhão, J., and Almeida, F. (2002). The archeological framework. In Zilhão, J., and Trinkaus, E. (eds.), Portrait of the Artist as a Child: The Gravettian Human Skeleton from the Abrigo do Lagar Velho and its Archeological Context. Trabalhos de Arqueologia 22, Lisbon, pp. 29-57.

Zilhão, J., Aubry, T., Carvalho, A. F., Baptista, A. M., Gomes, M., and Meireles, J. (1997). The rock art of the Côa valley (Portugal) and its archaeological context: first results of current research. Journal of European Archaeology 5: 7-49.

Zilhão, J., Aubry, T., Carvalho, A. F., Baptista, A. M., Gomes, M., and Meireles, J. (1998-99). Art rupestre et archéologie de la vallée du Côa. Premier bilan. Préhistoire et Anthropologie Méditerranéennes 7-8: 89-118.

Zilhão, J., Aubry, T., and Carvalho, A. F. (1999). L'art rupestre de la vallée du Côa. Aperçu général des problèmes de recherche et de gestion. Anthropologie et Histoire 110: 47-59. 